$1-1-1998$

\title{
Business Subsidies and the Dormant Commerce Clause
}

Dan T. Coenen

UGA School of Law, coenen@uga.edu

D bepress

\section{Repository Citation}

Dan T. Coenen, Business Subsidies and the Dormant Commerce Clause (1998),

Available at: https://digitalcommons.law.uga.edu/fac_artchop/857

This Article is brought to you for free and open access by the Faculty Scholarship at Digital Commons @ University of Georgia School of Law. It has been accepted for inclusion in Scholarly Works by an authorized administrator of Digital Commons @ University of Georgia School of Law. Please share how you have benefited from this access For more information, please contact tstriepe@uga.edu. 


\title{
Business Subsidies and
}

\section{the Dormant Commerce Clause}

\author{
Dan T. Coenen ${ }^{\dagger}$
}

\section{CONTENTS}

I. The Problem of Subsidies and the West LyNN CREanery Case 970

II. The Constitutionality of ORdinary Business Subsidies . . 976

A. Precedent . . . . . . . . . . . . . . . . . . 977

B. Policy . . . . . . . . . . . . . . . . . . . . . . . . . . 978

1. The Search for a Middle Ground, Considerations of "Form."

and Constitutional Histon. . . . . . . . . . . . . . 979

2. Functional Considerations . . . . . . . . . . . . 983

3. Constitutional Theon . . . . . . . . . . . . . . 997

a. Accountability ... . . . . . . . . . . . . . 998

b. Deliberative Decisionmaking . . . . . . . . . . . . 999

c. Collaborative Lawmaking . . . . . . . . . . 1000

4. A Recapitulation . . . . . . . . . . . . . . . . . . . 1002

III. THE West LyNN CREAMERY APPROACHES to Distinguishing

PERMISSIBLE AND IMPERMISSIBLE SUBSIDIES . . . . . . . . . . . 1003

A. Justice Stevens's Approach . . . . . . . . . . . . . . . 1003

1. The Surrogate-Representation Distinction ........ 1004

2. The Burden-and-Benefit Rationale . . . . . . . . 1007

B. Justice Scalia's Approach . . . . . . . . . . . . . 1010

C. Chief Justice Rehnquist's Dissent . . . . . . . . . . . . . 1016

IV. TOWARD a Functional FRAMEWORK FOR TAX-LINKAGE ANALYSIS . . . . . . . . . . . . . . . . . . . . 1020

A. Other Commentators' Approaches . . . . . . . . . . . 1020

1. The Low-Cost-Subsidy' and Efficient-Subsidy Principles . 1020

2. The Commerce-Creation Principle ............ 1023

$\dagger$ J. Alton Hosch Professor, University of Georgia School of Law B.S., University of Wisconsin. J D. Comell Law School. The author thanks Paul Heald. Walter Hellerstein, and James Smith for valuable comments on an earlier draft and Lance McMillian and Anna Freisell for heipful research assistance.

965 
3. The Industry-Specific-Tax Distinction . . . . . . . . 1026

B. Toward a Policy-Driven Principle for Distinguishing Permissible and Impermissible Subsidies . . . . . . . . . . . . . . . . 1029

V. ApPlying the Policy-Based LinKage Methodology . . . . . 1032

A. A Better Analysis for West Lynn Creamery . . . . . . . 1032

1. Fairness ..................... 1032

2. Federalism .................... 1033

3. Political Processes ................... 1034

4. Considerations of Form ............... 1035

B. Deciding Other Subsidy Cases . . . . . . . . . . . . 1037

1. The Source of Subsidy Money . . . . . . . . . . . 1038

2. The Segregated Fund ..................... 1040

a. Fairness and Federalism ............... 1040

b. Political Processes ................... 1041

c. Considerations of Form . . . . . . . . . . . . . . 1042

3. Simultaneity of Enactment . . . . . . . . . . . . . 1043

4. The Cumberland Farms II Conundrum . . . . . . . . . 1046

a. Fairness and Federalism . . . . . . . . . . . . . . 1049

b. Considerations of Form . . . . . . . . . . . . . . 1049

c. Political Processes .................... 1050

d. Constitutional Remediation ............. 1051

VI. CONCLUSION $\ldots \ldots \ldots \ldots \ldots \ldots \ldots \ldots \ldots \ldots \ldots \ldots \ldots$ 
For more than a century, the "dormant Commerce Clause" has safeguarded our "national "common market" ".2 from undue state interference. ${ }^{3}$ Time and again, the Supreme Court has drawn on this principle to strike down laws that favor local businesses over competitors engaged in interstate operations. ${ }^{4}$ Invoking the Commerce Clause, the Coun has condemned state "customs duties." It has outlawed price controls that strip away advantages of out-of-state producers. ${ }^{6}$ It has held unconstitutional even facially neutral buyer-protection legislation that diverts market share to in-state sellers. ${ }^{7}$ The Court has been especially aggressive in applying the dormant Commerce Clause to invalidate discriminatory state tax laws, including credits or exemptions that favor local businesses. ${ }^{8}$ Running through these decisions is a "strict rule of equality," which mandates that a state treat out-of-state commercial interests no worse than it treats its own. ${ }^{10}$

Despite the sweeping character of this dormant Commerce Clause nondiscrimination principle, "the cases suggest that states can favor local

\section{As stated in a leading treatise:}

The text of the commerce clause does not explain what happens if a state law affects interstate commerce but there is no direct federal legislation on point. The Court has responded by interpreting the affirmative grant of commerce power . . . as imposing some self-executing limitations on the scope of permissible state regulation.

John E. NOWAK \& RoNALD D. Rotunda. CONSTITUTIONAL LAW § 8.1, at 281 (Sth ed 1995) These selfexecuting limitations-which reflect the underlyng "rationale of the commerce clause . 10 create and foster the development of a common market among the states." $d$. at 282 -are somelimes referred to in shorthand form as the "dormant commerce clause," $d$. at 281. Professors Nowak and Rotunda explasn. "Without a dormant commerce clause, states would be free to enact legislation favoning local commeree and discriminating against out of state commerce in all cases where Congress has not legislated on a particular matter." Id.

2. General Motors Corp. v. Tracy. 117 S. Ct. 811.825 (1997) (quoung Hunt v Washington State Apple Adver. Comm'n, 432 U.S. 333, 350 (1977)).

3. See id. at 820,825 .

4. See generally LAURENCE H. TRIBE, AMERICAN CONSTIt TIONAL. LAw $\$ \S 6-1$ to -20. al $401-69$ (2d ed. 1988) (discussing key cases); Donald H. Regan. The Supreme Court and State Protectiontsm Mlakıng Sense of the Dormant Commerce Clause, 84 MICH. L. REv. 1091 (1986) (same).

5. H.P. Hood \& Sons v. Du Mond, 336 U.S. 525. 539 (1949).

6. See Baldwin v. G.A.F. Seelig, Inc., 294 U.S. 511.521 (1935).

7. See Hunt, 432 U.S. at 350.

8. See 1 Jerome Hellerstein \& Walter Hellerstein. State Taxation $74+01$ to $14(1993$ \& Supp. 1996) (collecting numerous cases); TRIBE, supra note 4. \$ 6-17. at 453-58 (same)

9. Halliburion Oil Well Co. v. Reilly, 373 U.S. 64, 73 (1963): see also. e.g.. Miaryland v Louisiana. 451 U.S. 725,759 (1981) (noting the requirement of "equality of treatment")

10. See, e.g., Henneford v. Silas Mason Co., 300 U.S. 577.581 (1937) (upholdıng a compensatıng use tax imposed by a state that collected a local sales tax. because the use tax permilted resident and nonresident sellers "to compete upon terms of equality").

11. See, e.g., Oregon Waste Sys., Inc. v. Department of Envtl. Quahty. 511 U S. 93. 99 (1994) (noting that "discrimination" in Commerce Clause terms "simply means differentul ireatment of in-state and out-ofstate economic interests"); Fort Gratiot Sanitary Landfill, Inc. v. Michigan Dep't of Nalural Resources, 504 U.S. 353, 361-63 (1992) (reaffirming application of the principle to discriminztson favonng in-county, as well as in-state, interests); Chemical Waste Mgmt., Inc. v. Hunt. 504 U.S. 334. 342 (1992) (clauming that "[o]nce a state tax is found to discriminate against out-of-state commerce, it is typically struck down without further inquiry"); Armco Inc. v. Hardesty. 467 U.S. 638. 642 (1984) (resteraung that a state may not use an "interstate element" as a basis for discrimination): City of Phladelphia v. New Jersey, 437 U S 617,627 (1978) (holding that the nondiscrimination principle targets government means as well as ends). 
businesses in one particular way: by awarding outright monetary subsidies. ${ }^{12}$ Because such bounties typically are made available only to in-state operations, they appear on their face to abridge the "prohibition against discriminatory treatment of interstate commerce." 13 At least before 1994, however, the Court seemed set in its view that monetary business subsidies lay beyond the reach of the dormant Commerce Clause. "Direct subsidization of domestic industry," the Court had decreed, "does not ordinarily run afoul of this prohibition."14

In its seminal decision in West Lynn Creamery, Inc. v. Healy, ${ }^{15}$ however, the Court signaled a potential retreat from this stance. In footnote fifteen of its opinion, which invalidated a discriminatory tax "rebate," noted: "We have never squarely confronted the constitutionality of subsidies, and we need not do so now." ${ }^{17}$ Many observers, as well as the concurring and dissenting Justices in West Lynn Creamery itself, read footnote fifteen as putting back on the table the question whether outright business subsidies violate the dormant Commerce Clause. ${ }^{18}$ The Court still has not ruled on the issue. Indeed, in its most recent dormant Commerce Clause decision, Camps Newfound/Owatonna, Inc. v. Town of Harrison, ${ }^{19}$ the Court reiterated its footnote fifteen disclaimer. ${ }^{20}$ In short, both Camps Newfound/Owatonna and

12. See infra text accompanying notes 41-45.

13. Boston Stock Exch. v. State Tax Comm'n, 429 U.S. 318, 329 (1977).

14. New Energy Co. v. Limbach, 486 U.S. 269, 278 (1988).

15. 512 U.S. 186 (1994).

16. Id. at 197 .

17. Id. at 199 n. 15.

18. See, e.g., Peter Enrich, Saving the States from Themselves: Commerce Clause Constraints on State Tax Incentives for Business, 110 HARv. L. REv. 377, 431 n.295 (1996) ("The Court left open the question whether a subsidy restricted to in-state businesses is constitutional if funded in a manner that does not burden out-of-state competitors ...."); id. at 443 (claiming that West Lynn Creamery "leaves scrious doubts about the Court's view of tax-financed subsidy programs"); Lisa Heinzerling. The Commencial Constitution, 1995 SUP. CT. REv. 217, 232 ("IIn West Lynn Creamery,] the Court pointedly refused 10 express general approval of subsidies for in-state business."); William L. Oemichen, Milk, State Taxes, State Subsidies, and the Commerce Clause: When States Cannot Tax an Agricultural Commodity To Fund a Subsidy for lis Struggling Industries, 18 HAMLINE L. REv. 415, 428 (1995) (stating that West Lynn Creamery "places in constitutional jeopardy the ability of states to subsidize domestic industries"); Christopher P. La Puma, Note, Massachusetts Tax and Subsidy Scheme Violates Commerce Clause: West Lynn Creamery, Inc. v. Healy, 48 TAX LAW. 641, 653 (1995) (concluding that West Lynn Creamery "has inadvertently cast doubt on the validity of subsidies themselves"); George P. Patterson, Note, Does the Commerce Clause Value Public Goods?: West Lynn Creamery v. Healy, 44 CATH. U. L. REv. 977, 984 (1995) ("In [West Lynn Creamery], the Court failed to resolve the issue of subsidies."); see also Cumberland Farms, Inc. v. Mahany (Cumberland Farms II), 943 F. Supp. 83, 90 (D. Me. 1996) ("In West Lynn Creamery, the Supreme Court did not directly address the issue of whether subsidies to in-state businesses are, in themselves, constitutional."); $c f$. Regan, supra note 4, at 1196 (arguing that the "Court should stand ready to reconsider what it has said about direct subsidies"); Michael Wells \& Walter Hellerstein, The Governmental-Proprietary Distinction in Constiutional Law, 66 VA. L. REV. 1073, 1130 (1980) ("TT]here is considerable room for controversy over whether the conflict between the purposes of the commerce clause and the power of the states to dispose freely of their own resources ought to be resolved in favor of the latter."). For discussions of the concurring and dissenting opinions in West Lynn Creamery, see infra Sections III.B-C.

19. 117 S. Ct. 1590 (1997).

20. See id. at 1605 . In particular, while concluding that "tax exemptions and subsidies ... differ in important and relevant respects," the Court declared that it would only "[a]ssum[e] arguendo . . . that a direct subsidy . . . would be permissible." Id. For a further discussion of Camps Newfoumd/Owatonna, see 
West Lynn Creamery pointedly invite a comprehensive reconsideration of the permissibility of subsidies under the dormant Commerce Clause.

In this Article, I seek to respond to the Court's overture with a treatment of this subject that moves progressively from the general to the specific. Part I examines key Supreme Court cases to show that the basic question of whether state business subsidies are constitutional remains open and imporant. Part $I$ then turns to how that question should be resolved, focusing on whether subsidies are fairly distinguishable from ostensibly equivalent, and concededly unlawful, discriminatory tax relief. The thrust of Part II is that both precedent and policy support the traditional, pre-West Lymn Creamery view that state subsidies almost always comport with the dormant Commerce Clause principle. In particular, Part II emphasizes that four considerations-rooted in form, fairness, federalism, and political processes-render subsidies less threatening to Commerce Clause values than economically comparable tax deductions, credits, and exemptions.

Part III then addresses the major question that Par II leaves open: How should courts distinguish the ordinary subsidy that is constitutional from the exceptional subsidy that is not? Part III suggests that none of the opinions in West Lynn Creamery-in which an exceptional subsidy was struck downoffers much useful guidance on this critical question. As a result, Part IV offers an alternative analytical framework for distinguishing the constitutional grant-in-aid from the unconstitutional assault upon our "federal free trade unit."21 In essence, this proposal calls upon courts to draw the line between permissible and impermissible subsidies by focusing on the same four factors already identified in Part II to distinguish ordinary subsidies from discriminatory tax breaks as a general matter. Accordingly, Part IV advocates an approach that asks whether the challenged subsidy-because of its linkage to a particular tax-shares the essential constitutional defects of a discriminatory tax break. Using the four factors, courts would consider the following: (1) whether, consistent with conventional property-based notions of fairness, the subsidy merely permits state residents to reap where they have sown; (2) whether invalidation of the subsidy frustrates the state's federalismbased interest in experimenting with responses to distinctive local needs; (3) whether the same political dynamics that unduly encourage adoption and retention of discriminatory tax relief (i.e., reduced visibility, heightened risks of entrenchment, lowered administrative costs, and the like) mark the challenged subsidy scheme; and (4) whether the subsidy is part of a program that resembles in form a protective tariff or kindred types of unconstitutional discriminatory taxation. ${ }^{22}$

\footnotetext{
infra text accompanying notes 64-68.

21. H.P. Hood \& Sons v. Du Mond. 336 U.S. 525. 538 (1949)

22. Part IV also suggests that the Court has effectuvely endorsed this sort of analysis in its long. established "market participant exception" to the dormant Commerce Clause Ser Wyoming v Ohlahoma.
} 
Finally, Part V considers how the analytic structure outlined in this Article will operate in the real world. Evaluating a range of hypothetical and actual cases, including West Lynn Creamery itself, Part V offers evidence that this policy-centered approach is as workable in practice as it is sound in theory. ${ }^{23}$

The questions addressed here involve high stakes ${ }^{24}$ and knotty analytical problems. ${ }^{25}$ Because business bounties take myriad forms, it would be impossible to address every constitutional question they might present. Nonetheless, this Article offers something that neither courts nor commentators have yet begun to supply: an analytic superstructure for evaluating monetary subsidies in the post-West Lynn Creamery era.

\section{The Problem of Subsidies AND the WEST LYNN CREAMERY CASE}

Although "[g]overnments have long used subsidies as economicdevelopment tools," ${ }^{26}$ state awards of cash grants to businesses raise obvious dormant Commerce Clause problems. ${ }^{27}$ In case after case, the Supreme Court

502 U.S. 437, 459 (1992) (recognizing the existence of the exception but finding no need to explore its applicability on the facts presented); South-Cent. Timber Dev. Co. v. Wunnicke, 467 U.S. 82, 99 (1984) (plurality opinion) (detailing the Court's earlier market participant decisions). For treatments of the market participant exception, see Thomas K. Anson \& P.M. Schenkkan, Federalism, the Dormant Commerce Clause, and State-Owned Resources, 59 TEx. L. Rev. 71 (1980); Benjamin C. Bair, The Dormant Commerce Clause and State-Mandated Preference Laws in Public Contracting: Developing a More Substantive Application of the Market-Participant Exception, 93 MiCH. L. REV. 2408 (1995); Dan T. Coenen, Untangling the Market-Participant Exemption to the Dormant Commerce Clause, $88 \mathrm{MiCH}$. L. REv. 395 (1989); Mark P. Gergen, The Selfish State and the Market, 66 TEx. L. REv. 1097 (1988); Paul S. Kline, Publicly-Owned Landfills and Local Preferences: A Study of the Market Participant Doctrine, 96 DICK. L. REV. 331 (1992); and Jonathan D. Varat, State "Citizenship" and Interstate Equality, 48 U. CIII. L. REV. 487 (1981).

23. This mode of analysis requires several revisitations of West Lynn Creamery during the course of this Article: first, in investigating what the Court has decided so far about the constitutionality of statc subsidies, see infra Part II; second, in examining whether there is merit in any of the methodologics suggested by the Justices in West Lynn Creamery for sorting good from bad subsidics, see infra Part III; and finally, in investigating whether the alternative methodology proposed here comports (as it surely must) with the actual outcome of the case, see infra Section V.A. Although this Article concerns far more than the propriety and impact of West Lynn Creamery, the recurring references to that case signal its centrality in any inquiry about the constitutionality of business subsidies.

24. See, e.g., William SChweke et al., Bidding for Business: ARe Cities and States Selling THEMSELVES SHORT? 19 (1994) (suggesting that nontax subsidies "are the fastest growing type of development incentive").

25. To gain a sense of these problems, see infra Section V.B.

26. Karen Tumulty, Why Subsidies Survive, TIME, Mar. 25, 1996, at 46, 46.

27. A number of articles touch upon the general subject of subsidies and the dormant Commerce Clause. See Coenen, supra note 22, at 473-78; Richard B. Collins, Economic Union as a Constitutional Value, 63 N.Y.U. L. REv. 43, 98-105 (1988); Enrich, supra note 18, at 44I-43; Heinzerling, supra note 18, at 232-34, 257-64; Regan, supra note 4, at 1193-202; Varat, supra note 22, at 540-45. Another treatment of subsidies appears in Walter Hellerstein \& Dan T. Coenen, Commerce Clause Restruints on State Business Development Incentives, 81 CORNELL L. REV. 789 (1996), which looks generally at both tax and nontax incentives for business development. That article, however, focuses on two subjects not addressed here: (1) whether the constitutionality of a subsidy should depend on its generality of application and, more particularly, on the state's targeting of a single firm with the design of attracting it to the state: 
has relied on the Commerce Clause to strike down state laws that "favor local businesses over out-of-state businesses."28 On their face, state subsidies seem to violate this principle because their availability to targeted businesses invariably hinges on engaging in business operations within the subsidygranting state. Similarly, the Court often has decried state action that "neutraliz[es] the advantage possessed by lower cost out-of-state producers."29 Yet monetary subsidies-no less than the protective tariffs that the Cour repeatedly has condemned ${ }^{30}$-have precisely this effect." It is not uncommon for international free trade pacts to restrict member nations' power to dole out monetary subsidies because such subsidies distort the efficient distribution of productive activities. ${ }^{32}$ Symmetry of logic suggests that statepaid subsidies should likewise offend any principle designed to safeguard our own "common national market among the states." ${ }^{33}$

The case against subsidies draws its greatest strength from the Court's unstinting use of the Commerce Clause to outlaw discriminatory tax breaks. ${ }^{\text {H4 }}$ Assume, for example, that the State of Oregon, wishing to help along a fashionable industry, enacts a law that gives any business that operates a

and (2) whether the constitutionality of subsidies should depend on the form of benetit the state awards (e.g., on whether the subsidy is a cash grant, a land grant. a forgivable loan. clc) These important subjects-as well as the problem of coupling subsidies with so-called "downstream restrants"-are not further considered in this Article. The "downstream restraints" problem, which is particulariy umporiant and complex, is separately considered in a number of other articles, uncluding Coenen, supra nole 22. at 463-73. 476-78; Kline, supra note 22, at 380-83; and Varat, supra note 22, at 560-64

28. Bacchus Imports, Lid. v. Dias, 468 U.S. 263. 272 (1984).

29. West Lynn Creamery, Inc. v. Healy, 512 U.S. 186, 194 (1994); see ulso, e g. Baldu in v G A F Seelig. Inc., 294 U.S. 511, 528 (1935) (asserting that states "may not insist that producers in other states surrender whatever competitive advantages they may possess"). Alliance for Clean Coal v Miller. 44 F.3d 591, 595 (7th Cir. 1995) (striking down the lilinoss Coal Act because it "has the same effect as a "tariff or customs duty-neutralizing the advantage passessed by lower cost out of state producers". (quoting West Lynn Creamery, 512 U.S. at 194)).

30. See infra notes $92-96$ and accompanying text.

31. See, e.g., Varat, supra note 22, at 543 (statıng that a "direct subsid) . seeds to reduce the competitive edge possessed by out-of-state business"): Nole. Funchonal Analssis. Subsidies, and the Dormant Commerce Clause, 110 HARv. L. REv. 1537. 1542 (1997) ("Both tanffs and subsidies. assurning no countervailing retaliatory action, allow in-state producers "who produce at higher cost to sell at or below the price charged by lower cost out-of-state producers." (footnote omtted) (quoung West Lynn Creamen. 512 U.S. at 195)).

32. For example, Professor Gergen reports that "[ (1]he European Economic Communily (EEC) generally prohibits subsidies that threaten to disrupt competution." Gergen. supra note 22. at 1137 n.209 (cilıng

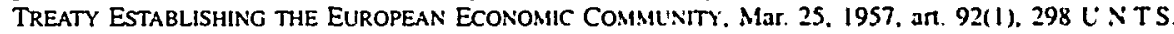
11, 51); see also General Agreement on Trade in Services. Apr. 15. 1994. Annex IB. an XV. 33 I L.M. 1167, 1179; RAJ BHALA, INTERNATIONAL TRADE LAW 790-800 (1996) (detalling restrictions imposed by the Uruguay Round Agreement on Subsidies and Countervaling Meatsures).

33. H.P. Hood \& Sons v. Du Mond, 336 U.S. S25. 538 (1949): see also Chnstopher R. Drahozal. On Tariffs $v$. Subsidies in Interstate Trade: A Legal and Economic Anulvsis, 74 WaSH U LQ 1127. 1143 (1996) ("The analogy between international trade and interstate trade is a close and useful one, states and nations undertake similar sorts of actions that have comparable economic effects ")

34. See Coenen, supra note 22, at 479-80 (discussing, among other cases. New Energ, Co v Lambuch. 486 U.S. 269 (1988); and Bacchus Imports, Lid. v: Dius. 468 U S. 263 (1984)) 
winery in the state an annual $\$ 25,000$ credit against state income taxes. What will happen if the law is challenged by an out-of-state winery that markets its product nationwide and thus owes and pays income taxes in Oregon? Existing authorities indicate that the credit would be unconstitutional because entitlement to it is overtly conditioned on wineries' conducting business operations in the taxing state. ${ }^{35}$

Now assume that Oregon takes another route. Instead of giving local winery operators the $\$ 25,000$ tax credit, the state collects in full all income taxes owed by wineries but also grants local wineries an annual $\$ 25,000$ monetary subsidy. As a matter of "economic realities"36-which the Court has often declared the proper focal point of Commerce Clause analysis ${ }^{37}$-the cash bounty produces the same result as the tax credit. ${ }^{38}$ The subsidy, after all, merely puts back in the local producers' coffers the same $\$ 25,000$ that the credit had kept there. Each mode of preference thus permits the in-state

35. See, e.g., Armco Inc. v. Hardesty, 467 U.S. 638, 642 (1984) (finding a violation of the antidiscrimination principle because "the gross receipts tax at issue . . . provides that two companies selling tangible property at wholesale in West Virginia will be treated differently depending on whether the taxpayer conducts manufacturing in the State or out of it"); Boston Stock Exch. v. State Tax Comm'n, 429 U.S. 318, 337 (1977) ("[N]o State may discriminatorily tax the products manufactured or the business operations performed in any other State."). Indeed, the credit most likely would be held unconstitutional even if it were conditioned on the establishment of new and additional winery operations in the state. Support for this conclusion comes from, among other sources, Westinghouse Electric Corp. v. Tully, 466 U.S. 388, 402-07 (1984), and a variety of lower court decisions, see Hellerstein \& Coenen, supra note 27. at 815 n.139, 818-19 (citing cases). To be sure, as Professor Hellerstein and I have noted, it is possible to distinguish Westinghouse from the tax-credit-for-a-new-business case. See id. at 814 ; see also Enrich, supra note 18, at 429 (noting that "the precedential value of the Westinghouse Electric ruling may be limited by the attention paid by the Court to idiosyncratic features of the New York credit provision"); Philip M. Tatarowicz \& Rebecca F. Mims-Velarde, An Analytical Approach to State Tax Discrimination Under the Commerce Clause, 39 VAND. L. REV. 879, 936 (1986) (emphasizing the distinctive feature of the credit at issue in Westinghouse, which not only provided an incentive for in-state business activity, but also penalized additional out-of-state activity); infra Subsection IV.A.2 (setting forth an argument for distinguishing development incentives from protectionist devices). Professor Hellerstein and I have also explained, however, that this narrow reading of Westinghouse is probably unwarranted. See Hellerstein \& Coenen, supra note 27, at 814-15. Indeed, even the leading proponents of a narrow reading of that case acknowledge that the Westinghouse Court "used language that suggested a very broad scope might be given to the concept of tax neutrality." Tatarowicz \& Mims-Velarde, supra, at 935.

36. Complete Auto Transit, Inc. v. Brady, 430 U.S. 274, 279 (1977).

37. See infra notes $189-190,405$ and accompanying text.

38. See Fireside Nissan, Inc. v. Fanning, 30 F.3d 206, 216 (Ist Cir. 1994) ("[W]e see no practical difference between the tax break offered to local liquor producers in Bacchus . . . and a 'dircct' cash subsidy to those same industries ... .); Carlson v. State, 798 P.2d 1269, 1278 (Alaska 1990) ("[Permitting a] state [to] subsidize its own residents in the pursuit of their business activities and not similarly situated nonresidents . . . seems economically indistinguishable from imposing a facially equal tax on residents and nonresidents while making it effectively unequal by a system of credits and exemptions. Such schemes have been struck down by the United States Supreme Court."); Enrich, supra note 18, at 442 (noting the "structural similarities between tax incentives and direct governmental subsidies and . . . their comparable practical effects on business decisionmaking"); Heinzerling, supra note 18, at 263 (noting the tariffduplicating effects of subsidies); Stanley S. Surrey, Tax Incentives as a Device for Implementing Government Policy: A Comparison with Direct Government Expenditures, 83 HARV. L. REV. 705, 717 (1970) ("A dollar is a dollar-both for the person who receives it and the government that pays it, whether the dollar comes with a tax credit label or a direct expenditure label."). 
operator to reduce prices and thereby increase market share in equal measure. ${ }^{39}$ In fact, the monetary subsidy may favor local winery operators even more than the tax break because the subsidy goes to all local operators, whether or not they generate sufficient income to produce a $\$ 25,000$ tax bill. $^{40}$

Does it follow that the monetary subsidy for local wineries is unconstitutional? At least before the Supreme Court decided West Lynn Creamery, the answer seemed to be "no." In New' Energy' Co. $v$. Limbach $^{42}$ for example, the Court distinguished an Indiana subsidy for locally produced ethanol while invalidating an Ohio tax exemption that had essentially the same economic effect. ${ }^{43}$ Unlike a resident-favoring lax break, the Court explained, "[d]irect subsidization of domestic industry does not ordinarily run afoul of [the dormant Commerce Clause] prohibition." The New Energy case, along with earlier authorities, signaled that states possess broad powers to award monetary subsidies for the exclusive benefit of in-state producers. $^{45}$

39. See Chemical Waste Mgmi.. Inc. v. Hunt. 504 U.S. 334. 351 (1992) (Rehnquist, C J . dissentung) (describing a subsidy as equivalent to a tax break): Texas Monthly. Inc. V. Bulloch. 489 U'S 1. 34 (1989) (Scalia, J., dissenting) (noting that "tax exemptions may have the same economic effect as stale subsidies"). Larry Alexander, A Unifying Theory?: Impossible, 72 DENV. U. L. REV. 1007. 1007 (1995) (stressing the difficulties of "draw[ing] the line between illegitimate tax and regulatory discnmination on the one hand. and legitimate subsidy on the other"): Collins, supra note 27, at 98 ("Dinect cash subsidies to local producers, if derived from general tax revenues, have almost the sime cconomic effect on extema! competition as tariffs."); Saul Levmore, Interstate Explottatton and Judictal Inteniention. $69 \mathrm{~V} \mathrm{~A}_{\mathrm{L}} \mathrm{REV}$ 563, 566 (1983) (noting that subsidies and taxes "may have the same effects"): Surrey. supra note 38, at 714 ("[B]udgetary experts can take any tax expenditure and devise a budgetary expenditure approash to serve the same goals as a direct expenditure."): Varat. supra note 22, at 5+4 (noung that the "result of an effective local subsidy program will be the same as that of a (ax"): The Supreme Court. 1975 TermLeading Cases, 90 HARV. L. REv. 1. 60 (1976) (noting that subsidies "may provide local firms with a competitive edge by creating price differentials between local and out-of-state fims") For an arucle that emphasizes this point in attacking current doctrine, see Michael J. Polelle. A Crittute of the Harket Participant Exception, 15 WHITTIER L. REV. 647 (1994).

40. See Surrey, supra note 38 , at 72 I (notung that, unlıke a monetary subsidy, a tax credit "would not help a new business experiencing initial losses and struggling to stas alive. or it would help only by deferring into the future, through a carry-forward provision. benefits needed at once") Notably. much literature is devoted to the business of distinguishing subsidies from tariffs. See. e.g.. Drahozal, supra note 33, at 1143-56; Levmore, supra note 39. at 577-80. But the difficult question is not whether subsidies differ from tariffs; instead, it is whether subsidies differ from discrimınatory tax expenditures. That is the subject of this Article.

41. See supra notes $14-18$ and accompanying text.

42. 486 U.S. 269 (1988).

43. See infra notes $242-250$ and accompanying text (discussing the Court's reasoning)

44. New Energy, 486 U.S. at 278.

45. See Hellerstein \& Coenen. supra note 27, at 840-46 (discussing pre-H'esi Lynn Creamery subsidy cases in detail); see also Daniel A. Farber \& Rober E. Hudec. Free Trade and the Regulaton State A GATT's-Eye View of the Dormant Commence Clause. 47 VAND. L. REV. 1401.1412 n 32 (1994) ("Cases involving state proprietary functions and subsidies belong to yet another calegory. such laws being generally immune from [dormant Commerce Clause] scrutıny."). 
Against this backdrop, West Lynn Creamery came before the Court. At issue was the constitutionality of a Massachusetts law designed to shore up the state's small and struggling dairy industry. The program had two components. First, it forced Massachusetts milk dealers to pay into a segregated fund a charge on all milk sold, regardless of its place of origin. Second, it mandated periodic distributions from this fund exclusively to in-state dairy farmers. ${ }^{46}$

Writing for five members of the Court, Justice Stevens found that the Massachusetts tax-and-subsidy package was unconstitutional. The scheme, the Court ruled, operated "in effect" as a "protective tariff."47 Because the subsidies constituted a de facto "rebate" of the milk sales levy, ${ }^{48}$ the program "as a whole"49 offended the Court's ban on "state statutes that clearly discriminate against interstate commerce." "50

In a concurring opinion joined by Justice Thomas, Justice Scalia faulted the majority for writing so broadly as to imperil all state subsidy programs. Justice Scalia was prepared to declare the distinctive Massachusetts scheme unconstitutional, but only on the narrow ground that the milk taxes had gone into and back out of a "segregated fund." 51 For Justice Scalia, if the milk producer subsidy had been paid "from the general revenues," it would have been constitutionally unobjectionable "with or without nondiscriminatory taxation of the [milk] industry.",52

Chief Justice Rehnquist filed a dissenting opinion joined by Justice Blackmun. In their view, the Massachusetts program embodied nothing more than a constitutionally "evenhanded" tax combined with the sort of local producer subsidy that cases like New Energy had endorsed. ${ }^{53}$ The dissenters' focus of concern, however, was not the majority's invalidation of the program at issue in West Lynn Creamery itself. Instead, tracking the mood of Justice Scalia, the Chief Justice voiced alarm that the majority's reasoning might well portend the demise of all state monetary subsidies. ${ }^{54}$ Justice Scalia found that the majority opinion created this risk because, in his view, it invoked "every free-market snippet of reasoning" discoverable in "the entire corpus of negative-Commerce-Clause opinions." ${ }^{55}$ For Justice Scalia, the majority's noncontextual parroting of these passages reflected the "sweeping" principle "that every state law which obstructs a national market violates the Commerce

\footnotetext{
46. See West Lynn Creamery, Inc. v. Healy, 512 U.S. 186, 190-91 (1994).

47. Id. at 197.

48. Id.

49. Id. at 201 .

50. Id. at 192 (quoting New Energy Co. v. Limbach, 486 U.S. 269, 274 (1988)).

51. Id. at 210 (Scalia, J., concurring).

52. Id.

53. Id. at 214 (Rehnquist, C.J., dissenting).

54. See id. at 213.

55. Id. at 207 (Scalia, J., concurring).
} 
Clause," including the inevitably market-distorting state law that bestows a business subsidy. ${ }^{56}$

The central flaw in Justice Scalia's depiction of the majority opinion is, ironically, that he focused only on "snippets" of the majority's analysis. In fact, the West Lymn Creamery majority signaled-at no fewer than three separate points in its opinion-that its decision was not meant to undermine the ordinary producer subsidy. ${ }^{57}$ Justice Scalia simply did not deal with these telling passages in a satisfying way. Instead, he dismissed them as susceptible to meaning at most that the Commerce Clause countenances subsidies paid to "the local hardware store" and other businesses so small that they "are not competing with businesses out of State." 58 This reading of the majority opinion is hard to comprehend, however, because the majority's reasoning did not focus at all on whether subsidies were paid to small or large businesses. Instead, in striking down the Massachusetts program, the Cour emphasized the distinctly problematic economic and political effects it perceived in the state's "conjoining a tax and subsidy." 59 As the majority stressed, the case involved neither a freestanding tax nor a freestanding subsidy but rather a novel program that "coupled" a subsidy with a simultaneously enacted tax. ${ }^{\infty}$ It was this program "as a whole" that raised constitutional difficulties and this "entire program" that the Court accordingly invalidated. ${ }^{61}$ In short, the majority's analysis permitted, and indeed encouraged, lower courts to distinguish the subsidy that is "standing alone"62 from an "integrated" program that involves both "contributions to" and "distributions from" a subsidy fund."

56. Id.

57. First, the Cour expressly assumed that a subsidy pand to Massachusetts dary farners "would be constitutional standing alone." Id. at 199 (majonty opınion). Second. after noung that the Court had never "squarely confronted the constitutionality of subsidies." the majortly swiftly (and with an unquestioning citation to New Energy) added: "We have, however. noted that "[d]ıreet substdization of domestic industry does not ordinarily run afoul' of the negative Commerce Clause." Id at 199 n.15 (quoting New Energy Co v. Limbach, 486 U.S. 269, 278 (1988)). Finally, in the body of its upinion, the majonty asserted-again without qualification-that "[a] pure subsidy funded oul of the general revenue ordinanly imposes no burden on interstate commerce." ld. at 199.

58. Id. at 208 (Scalia, J., concumng).

59. Id. at 199-200 (majority opinion) (emphasis added), see also Heınzerlıng. supra note 18. at 263 ("II]n West Lynn Creamen; the Court took pains to disunguish a pure subsidy funded out of the general revenue' from the tax and subsidy scheme developed by Massachusetts."): Patterson, supra note 18, at 1001 ("In [West Lynn Creamen], the Supreme Coun held that even though a tax and a subsidy may not individually violate the Commerce Clause, a violation may occur when the (wo are used in conjunction ")

60. West Lynn Creamen, 512 U.S. at 200.

61. Id. at 201 .

62. Id. at 199.

63. Id. at 201; see also Drahozal. supra note 33. at 1165 n 194 ("Some commentators argue that West Lynn Creamen casts doubt on the constitutionality of all state subsidies. . . [But that] fear should be unwarranted."); Heinzerling, supra note 18, at 221-22 ("State and local governments (probably) may favor their own citizens in distributing subsidies from general tax revenues ") 
The Court's recent decision in Camps Newfound/Owatonna v. Town of Harrison $^{64}$ swept away any doubt about whether West Lynn Creamery embodied a de facto disallowance of state subsidy programs. At issue in the case was whether a state could condition a property tax exemption for nonprofit corporations, claimed by fee-charging camps, on their provision of services primarily to residents of the state. In defending the tax exemption, the state relied on the Court's earlier subsidy-endorsing authorities, particularly New Energy. The Court, however, invalidated the discriminatory exemption, noting that the distinction between subsidies and tax breaks "is supported by scholarly commentary as well as precedent, and we see no reason to depart from it." ${ }^{\prime 5}$ The Court's logic in Camps Newfound/Owatonna thus seems to provide support for the conclusion-diametrically opposed to the one drawn by Justice Scalia in West Lynn Creamery-that state subsidies (unlike equivalent tax breaks) are ipso facto constitutional. The Court, however, made no such pronouncement, for its critical observation on this score came only in the context of refusing to uphold a discriminatory tax break on the ground that it was functionally indistinguishable from a purportedly constitutional subsidy ${ }^{66}$ As a result, the Court deemed it appropriate to do nothing more than "[a]ssum[e], arguendo, that . . . a direct subsidy benefitting only those [businesses] serving [local] residents would be permissible." ${ }^{67}$ In other words, the Court did not reach the question whether the hypothesized subsidy, or any subsidy, should itself survive constitutional challenge. Instead, the Court cautiously reserved judgment on all such matters, emphasizing - just as clearly as it had in West Lynn Creamery-that "we need not address these questions today." 68

What should the Court do tomorrow when it encounters challenges not to discriminatory tax rebates or credits, but to business subsidies that take the form of outright cash grants? I now turn to this question.

\section{THE CONSTITUTIONALITY OF ORDINARY BUSINESS SUBSIDIES}

The largest question raised by West Lynn Creamery and Camps Newfound/Owatonna is the one that the Court expressly reserved: whether ordinary state subsidy programs comport with the dormant Commerce Clause. This question, in turn, requires an inquiry into whether there is a basis for

64. 117 S. Ct. 1590 (1997). 48).

65. Id. at 1606 (citing Enrich, supra note 18, at 442-43; Hellerstein \& Coenen, supra note 27, at 846 -

66. See id. at 1605-06.

67. Id. at 1605 .

68. Id. 
treating subsidies differently from the economically comparable discriminatory $\operatorname{tax}$ breaks the Court often has invalidated. ${ }^{69}$ Notwithstanding the Court's ardent aversion to discriminatory taxation, both precedent and policy support the traditional view that ordinary subsidies are exempt from Commerce Clause attack.

\section{A. Precedent}

Professor Hellerstein and I have demonstrated elsewhere that abandonment of the traditional hands-off approach to subsidies would mark a striking departure from a long and strong line of Supreme Court precedents. ${ }^{70}$ Perhaps most significantly, abandoning the traditional view would seem at odds with $C \& A$ Carbone, Inc. v. Town of Clarkstown," a case decided within five weeks of West Lynn Creamery itself. ${ }^{72}$ In Carbone, the Cour struck down an ordinance that required delivery of local trash to a single, town-approved waste treatment facility. In finding that the ordinance unlawfully discriminated against out-of-state waste handlers, however, the Court emphasized that municipal subsidization of the facility provided a permissible, less restrictive alternative for ensuring the facility's continued operation. "In other words, the Court in Carbone specifically endorsed the town's ability to direct a monetary subsidy to a local competitor in an interstate market. ${ }^{2 s}$

As Professor Hellerstein and I have noted, it is possible to read Carbone in a narrow way that does not necessarily approve of discriminatory subsidization of local industry:

Carbone does not say that the power to subsidize includes the power to discriminate; it would be consistent with Carbone, for example, for the Court to require the extension of any state subsidy presently

69. See supra notes $8-11$ and accompanying text.

70. See Hellerstein \& Coenen, supra note 27. at 839-46. For post-West Lunn Creamen case law that supports this view, see USA Recycling. Inc. v. Town of Babylon, 66 F.3d 1272. 1291 (2d Cir 199S). in which the cour declared that "local governments are perfectly free. as market parucipants, to use economic incentives to benefit local businesses." The most significant pre-West Lymn Creamen case may be Hughes v. Alexandria Scrap Corp., 426 U.S. 794 (1976). See. e.g.. Regan. supra note 4. al 1196 n 202 (noung that Hughes suggests that a straightforward production subsidy for local producers is constitutionally permissible).

71. 511 U.S. 383 (1994).

72. Carbone was decided on May 16, 1994. See 511 U.S. at 383. West Lisnn Creamen was decided on June 17, 1994. See West Lynn Creamery. Inc. v. Healy. 512 U.S. 186. 186 (1999).

73. See Carbone, 511 U.S. at 394.

74. See Hellerstein \& Coenen, supra note 27, at 842 (notıng, in particular, that all nine Justıces in Carbone recognized the state's power to subsidize). For a recent decision that draws on this feature of Carbone, see USA Recycling, 66 F.3d at 1292, which relied on Carbone to uphold a spending scheme that channeled local waste to a local facility. 
awarded operators with in-state facilities to similarly situated out-ofstate operators, at least if those out-of-staters pay state taxes. ${ }^{75}$

This tightfisted translation of the approved power to subsidize, however, should strike most readers as farfetched. First, when one learns that "the town may subsidize the facility through general taxes,"76 one is not likely to assume that the same support must be channeled to other facilities as well. Second, a requirement of nondiscriminatory subsidization conflicts with the Court's overarching goal of identifying an alternative means of ensuring the long-term operation of the particular waste treatment facility involved in the Carbone case. After all, if the government must subsidize local and nonlocal waste-handling facilities in a nondiscriminatory way, there can be no assurance that the local facility will prosper. In fact, in light of the competitive advantages nonlocal facilities presumably already enjoy, ${ }^{77}$ nondiscriminatory subsidization may not advance the government's purposes at all. In sum, the more natural and policy-sensitive reading of Carbone indicates that the Court approved the power of state and local governments to subsidize local business operations without subsidizing nonlocal operations. Thus, Carbone strongly supports the constitutionality of ordinary state subsidy programs.

\section{B. Policy}

Carbone and other cases-including West Lynn Creamery itself-provide ammunition for the argument that monetary subsidies are constitutional as a general rule. ${ }^{78}$ The cases, however, can hardly be deemed dispositive, particularly in light of footnote fifteen in West Lynn Creamery and its reiteration in Camps Newfound/Owatonna. ${ }^{79}$ The question thus remains whether the Court's traditional acceptance of discriminatory subsidies makes good sense. In particular, when one looks at the full body of dormant Commerce Clause cases, a single key question arises: How can the tolerance the Court has shown toward discriminatory subsidies be squared with the intolerance it has directed toward discriminatory tax breaks?

\footnotetext{
75. Hellerstein \& Coenen, supra note 27 , at $843-44$.

76. Carbone, 511 U.S. at 394 (emphasis added).

77. See id. (acknowledging the town's argument that "special financing is necessary to ensure the longterm survival of the designated facility").

78. See Zenith/Kremer Waste Sys., Inc. v. Western Lake Superior Sanitary Dist., 558 N.W.2d 288, 292 n.l (Minn. Ct. App. 1997) (citing West Lynn Creamery as "approving of subsidies funded out of general revenues"); see also Drahozal, supra note 33, at 1144 (asserting that "the Court seems likely to continue to approve of state subsidies" after West Lynn Creamery); Hellerstein \& Coenen, supra note 27. at 839-40 (arguing that West Lynn Creamery supports the constitutionality of most state subsidies); stipra notes 57-63 and accompanying text (discussing the reasoning of West Lynn Creamery).

79. See supra notes $17-20$ and accompanying text.
} 


\section{The Search for a Middle Ground. Considerations of "Form." and Constitutional History}

One way to approach this question is from a "big picture" point of view. The theme of this picture is that the task of reconciling interests in federalism and nationalism in dealing with financial preferences afforded local businesses is one of enormous difficulty. ${ }^{80}$ There is much room for disagreement in this field, and battles over constitutional policy are destined to be hard-fought. ${ }^{81}$ Against this backdrop, common sense suggests the wisdom of avoiding an allor-nothing approach. ${ }^{82}$

The most apparent first step toward a middle ground position is to say that (in general) local favoritism worked through tax breaks is unconstitutional, while (in general) local favoritism effectuated through monetary payments is not. From this perspective, it is not persuasive to say that subsidies and tax breaks must be treated identically because "in substance" they operate the same way. ${ }^{83}$ Instead, the substance of the matter-at least if some plausible distinction between subsidies and tax breaks can be found-is that the Court's general willingness to uphold monetary subsidies itself tends to justify its unwillingness to uphold comparable tax breaks (and vice versa).

As one assesses this half a loaf approach, Carbone may again be instructive. The issue in that case was whether the town could insist that all solid waste within its borders be shipped to a local waste treatment facility for disposal at an above-market price. ${ }^{84}$ The Court recognized that this forced use rule was simply a "financing method" put in place to keep the local facility in operation. $^{85}$ The Court struck down the rule, however, because monetary

80. Cf. Westinghouse Elec. Corp. v. Tully. 466 U.S 388, 403 (1984) (citıng "the delicate balancing of the national interest in free and open trade and a State"s interest in exercising its taxing powers").

81. An interesting illustration of the divergence of stances in this area is provided by commentators. treatments of tax-based business development incentives. Various observers have suggested that (I) virtually all such business development incentuves are unconstitutional, see Ennch, supra note 18, at 38081, 448-67; (2) virtually no such business developenent incentues are unconsttutional. see Tatarowicz \& Mims-Velarde, supra note 35, at 928-37; (3) a distunction should be drawn between incenuves that accompany an income or gross receipts tax as opposed to those that aecompany a property or sales tax. see Hellerstein \& Coenen, supra note 27, at 816-34; and (4) a distunction might be drawn between excmptions. deductions, or credits that accompany a "broad-based state tax" and those that accompany an "Industryspecific" tax, see Drahozal, supra note 33. at 1167 . For an indication of the differeni views on how courts should treat monetary subsidies, see infra Section IV.A.

82. Cf. Ohio v. Roberts, 448 U.S. 56. $68 \mathrm{n} .9$ (198u) (lauding "the Courn's demonstrated suceess in steering a middle course among proposed alternatives" in the junsprudence concerning hearsay and the Confrontation Clause).

83. E.g., Associated Indus. v. Lohman. 511 U S 641.655 (199.4) (suggestung that judictal analysis under the dormant Commerce Clause should focus not on "malten of form." but on how state laws work "in substance").

84. C \& A Carbone, Inc. v. Town of Clarkstown. 51I U S 383. 383 (1994) (noung that the "Tupping fee ... exceeded the disposal cost of unsorted solid waste on the prisate marhet")

85. Id. at 393 . 
subsidization provided a "less restrictive alternative" for achieving this end ${ }^{86}$ In other words, the accepted availability of one form of state action that advantaged local over nonlocal operations served to justify the rejection of another. And the form that the Court deemed acceptable was the monetary subsidy.

Perhaps Carbone is not helpful in this context because to say that a subsidy is a less restrictive alternative to a forced use rule is not to say that a subsidy is a less restrictive alternative to an economically equivalent tax break. Indeed, the very statement that the subsidy and the tax break are "economically equivalent" suggests that, in terms of financial and competitive consequences, the former is not "less restrictive" than the latter. But maybe that does not matter. Tax breaks and subsidies differ at least as a matter of form, ${ }^{87}$ and the Court has found this formal difference significant outside the dormant Commerce Clause context. ${ }^{88}$ In addition, despite decades of hand-wringing about the controlling force of substance, ${ }^{89}$ the Supreme Court has recognized more than once that form can play a dispositive role in dormant Commerce Clause cases. ${ }^{90}$

Does it follow that the Court should build its dormant Commerce Clause doctrine around the "formal" difference between subsidies and tax breaks even assuming their "functional" equivalence? There are at least historical reasons for saying that it should. The Framers of the Commerce Clause, after all, took focused aim, not at subsidies, but at disfavored forms of taxation, ${ }^{91}$ particularly the protective tariff. ${ }^{92}$ Under the Articles of Confederation, states

86. Id. at 394 (citing New Energy Co. v. Limbach, 486 U.S. 269, 278 (1988)).

87. See Hellerstein \& Coenen, supra note 27 , at 868-70.

88. See Mueller v. Allen, 463 U.S. 388, 397 n.6 (1983) (distinguishing "outright grants" from "a genuine tax deduction" in applying the Establishment Clause even though "the economic consequences of the program in Nyquist and that in this case may be difficult to distinguish" (citing Committce for Pub. Educ. v. Nyquist, 413 U.S. 756 (1973))); Walz v. Tax Comm'n, 397 U.S. 664, 675 (1970) (holding that a tax break for church property did not violate the Establishment Clause, in part because the difference between subsidies and tax exemptions is one of constitutional significance). Notably, the Court drew upon this aspect of the Court's Establishment Clause jurisprudence in finding no dormant Commerce Clause violation in Camps Newfound/Owatonna. See Camps Newfound/Owatonna v. Town of Harrison, $117 \mathrm{~S} . \mathrm{Ct}$. 1590, 1605 nn.23-25 (1997).

89. See, e.g., Complete Auto Transit, Inc. v. Brady, 430 U.S. 274, 279 (1977).

90. See Dan T. Coenen \& Walter Hellerstein, Suspect Linkage: The Interplay of State Taxing and Spending Measures in the Application of Constitutional Antidiscrimination Rules, 95 MiCH. L. REv. 2167 , 2191-93 (1997) (discussing Oklahoma Tax Comm'n v. Chickasaw Nation, 515 U.S. 450 (1995); Oklahoma Tax Comm'n v. Jefferson Lines, Inc., 514 U.S. 175 (1995); Quill Corp. v. North Dakota, 504 U.S. 298 (1992)).

91. See Letter from James Madison to J. Cabell (Feb. 13, 1829), in 4 LETTERS AND OTHER WRITINGS OF JAMES MADISON 14-15 (Congress ed., Philadelphia, J.B. Lippincott \& Co. 1865) (noting that the Commerce Clause "grew out of the abuse of power by the importing states in taxing the non-importing").

92. See, e.g., Collins, supra note 27 , at 80 (citing tariffs as the "paradigm examples" of "categorical discrimination" barred by the Commerce Clause). 
could and did impose tariffs on the importation of out-of-state goods. ${ }^{93}$ These tariffs (along with other protectionist measures) precipitated retaliation by neighboring states. ${ }^{94}$ And it was primarily the pre-constitutional proliferation of such commercial impediments that brought about the Philadelphia Convention and the Commerce Clause itself. ${ }^{95}$

Responding to the Framers' focused concern about protective tariffs, the Court condemned them in its earliest expositions of the dormant Commerce Clause principle. ${ }^{96}$ Building on this foundation, the Court also has struck down discriminatory tax exemptions and credits, ${ }^{97}$ in large part because states can use these devices to disassociate taxes from tariffs in name while duplicating tariffs in effect. If, for example, a state puts a one percent tax on all goods sold at wholesale, but then exempts from the tax all goods produced in the state, the tax will operate just like a tariff: Charges will be imposed on all imported goods, while no charge comes to rest on goods made by local firms. ${ }^{98}$ To be sure, there are differences between many discriminatory tax

93. See JOHN FISKE, THE CRITICAL PERIOD OF AMERICAN HISTORY 144-45 (1916) ("IT) he different states, with their different tariff and tonnage acts, began to make commercial war upon one another "): Drahozal, supra note 33, at 1180 n.267 ("Without a doubt . . . there were significant disputes between the states during the confederation era conceming tanffs on goods imported from other states."): Note. Problems with State Aid to New or Expanding Businesses. 58 S. CAL. L. REv 1019. 1026 (1985) ("Before ratification . . . individual states levied tariffs on the products of other states.")

94. See Regan, supra note 4, at 1114 ("TThe Framers) saw states enacting protectionist restnctions. they saw other states retaliating."); see also Hughes v. Oklahoma. 441 U.S. 322. 325.26 (1979) (noung "tendencies toward economic Balkanization that had plagued relations among the Colonies and later among the States under the Aricles of Confederation"): Baldwin v. G.A.F Seelig. Inc . 224 U S 511. 522 (1935) (pointing to "rivalries and reprisals that were meant to be averted"); of C \& A Carbone, Inc $\vee$ Town of Clarkstown, 511 U.S. 383, 390 (1994) (citing as a rationale for the prohtbition on protectionist laws the prevention of retaliation by other states): THE FEDER ALIST No. 42. at 268 (James Madison) (Clinton Rossiter ed., 1961) (bemoaning duties as inviting "unceasing animosilies" and "senous internptions of the public tranquility").

95. See, e.g., Hood \& Sons v. Du Mond, 336 U.S. 525. 533-34 (19-49) (citung "commereal warfare" among the states following the American Revolution as the condition prompting the movement for the Constitution and asserting that the need for "centralized regulation of commeree" was fully understood by all states); Collins, supra note 27, at 52 ("Most histonans believe that commereial issues galvanized the call for the Convention and were an importani incentuve for ratufication."). For a recent recapitulation of this point, see Carbone, 511 U.S. at 414 (Souter, J.. dissentıng), which notes that "The Framers sought to dampen regional jealousies in general and, in particular, to eliminate retaliatory tanffs, which had poisoned commercial relations under the Articles of Confederation."

96. See, e.g., Guy v. Baltimore, 100 U.S. 434,443 (1879): Collans, supra note 27. at 81 (noting that "the Cour has consistently stuck down state and local 'drummer' taxes on local agents of oulside producers" because they "had precisely the same effects as tanffs"): see also WC M. Window Co. v. Bernardi, 730 F.2d 486, 493 (7th Cir. 1984) ("IO)ne thing is clear. a state may not erect a tanff wall protecting its industries from the competition of industnes in other states. . .").

97. See, e.g., Westinghouse Elec. Corp. v. Tully. 466 U S 388 (1984): Maryland v. Lousstana. 451 U.S. 725 (1981). See generally Associated Indus. v. Lohmun. 511 U.S. 641.647 (1994) (charactenzing "the fundamental command of the Clause as being that 'a State may not tax a transaction or incident more heavily when it crosses state lines than when it occurs enturely within the State"' (quoung Arnco Inc. v Hardesty, 467 U.S. 638, 642 (1984))).

98. See Drahozal, supra note 33, at 1167 n. 198 ("Of course, if the exemptions from a broad-based tax were extensive enough-such as an exemption for all domestically produced goods-even such a tax could operate as a tariff (on all imports into the state)."). 
laws and the archetypical protective tariff. ${ }^{99}$ But there is enough resemblance in general that the Court has stood on steady ground in broadly holding discriminatory taxation unconstitutional.

The anti-tariff principle, however, does not comfortably reach the simple subsidy precisely because it is not "analogous in form" to a discriminatory $\operatorname{tax} .{ }^{100}$ As we have seen, "economic equivalence alone has . . . not been (and should not be) the touchstone of commerce clause jurisprudence."101 Thus the distinct formal difference between the cash subsidy and the protective tariff suggests the dubious legitimacy of any effort to strike down the former by way

99. In particular, many resident-favoring tax breaks-unlike true tariffs-favor in-state business producers not only at the expense of direct out-of-state competitors, but also at the expense of other in-state producers, inciuding producers of substitute goods. This renders such tax breaks less problematic than tariffs both as a matter of economic effect (because discrimination in favor of in-state producers is not complete) and as a matter of political process theory (because in-state producers of substitutes can act as "surrogate representatives" of out-of-staters disadvantaged by the discriminatory tax). See infra text accompanying note 202. As discussed below, see infra notes $365-370$ and accompanying text. Bacchits Imports, Ltd. v. Dias, 468 U.S. 263 (1984), provides an example of the sort of targeted tax break that is less problematic than a true tariff.

The differing impacts of a targeted tax break and of a true tariff on differing calcgories of produccrs are shown in the following chart:

\begin{tabular}{|l|l|l|}
\hline PARTIES AfFected & TARIFF & TARGETED TAX BREAK \\
\hline In-State Producers of the Product & Helped & Helped \\
\hline In-State Producers of Substitutes & Helped & Hurt \\
\hline Out-of-State Producers of the Product & Hurt & Hurt \\
\hline Out-of-State Producers of Substitutes & Helped & Hurt \\
\hline
\end{tabular}

It may be said that tariffs are rendered less problematic than targeted tax breaks because out-of-state producers of substitutes are helped by a tariff but hurt by a targeted tax break. For example, the tax in Bacchus Imports hurt out-of-state producers not only of fruit wine, but also of sherry because it is a fruitwine substitute; in contrast, if Hawaii had put a tariff only on out-of-state fruit wine, the cconomic disadvantaging of that product would have helped out-of-state producers of sherry. This "helping" effect of the tariff on out-of-state producers of substitutes, however, is not nearly as significant as the help tariffs give to in-state producers of both the tariffed product and the tariffed product's substitutes. Why? Because this dual effect predictably sweeps away (at least in substantial part) all in-state producer opposition to the protective tariff.

The targeted tax break, in contrast, must pass and persist in the face of inevitable opposition by instate producers of substitutes because of the "price differential that the exemption will permit." IJl. at 269. In short, at least from a political process perspective, a true tariff is more constitutionally problemutic than a tax break afforded to a specific industry from a generally applicable tax that reaches substitutes produced in-state. Of course, the extent of this difference will vary as the number and strength of in-state substitutes grows. At least when there are substantial in-state substitutes, however, it seems clear that the targcted tax break is less problematic than the tariff. See, e.g., Collins, supra note 27, at 70-71 (noting the importance of market substitutes); Note, supra note 93, at 1031 (noting that "consumption of steel substitutes, such as aluminum, will be depressed if aluminum producers do not enjoy comparable external subsidies").

100. Regan, supra note 4 , at 1201 .

101. Oklahoma Tax Comm'n v. Jefferson Lines, Inc., 514 U.S. 175, 196 n.7 (1995); see supra text accompanying note 90 (noting the Supreme Court's prior recognition of this point). 
of a principle directed at the latter. ${ }^{102}$ This is especially true because the historical evidence suggests that subsidies were in fact uncontroversial in the pre- and post-framing period. ${ }^{103}$ Plainly, if the Framers drew a distinction between tariffs and subsidies, there is a powerful originalist argument for the Court to draw that distinction too. ${ }^{104}$

\section{Functional Considerations}

Even if we dismiss this history-driven argument as unduly formalistic, matters of substance lie behind the traditional judicial unwillingness to equate subsidies and tax breaks. ${ }^{105}$ Commentators and courts have argued, for

102. See Coenen, supra note 22, at 478-79; Hellerstein \& Coenen, supra note 27, at 847-48; Regan. supra note 4, at 1194 ("[A] discriminatory law is hot analogous in form to the traditional instruments of protectionism if the discrimination consists solely in channelıng to locals benefits . . stmply consistıng of . . . state funds."); see also Quill Corp. v. North Dakota, 504 U.S. 298. 312 (1992) ("Under the Arueles of Confederation, state taxes and duties hindered and suppressed interstate commerce: the Framers intended the Commerce Clause as a cure for these structural ills. . It is in this light that we have interpreted the negative implication of the Commerce Clause."): Henneford v Silis Miason Co. 300 U S 577. 586 (1937) (upholding a compensating use tax because it cannot be "stigmatized as equivalent to a protective tanfl")

103. As Drahozal writes:

[T] he historical record supports the view that bountses should be constitutional Bountles were plentiful during the colonial period. Although the use of bountues declined dunng the confederation era (mainly for budgetary reasons). they contınued to be used with little or no complaint. Moreover, states continued to enact bounties after the rattication of the Constitution. suggesting that bounties had not become unlawful

Drahozal, supra note 33, at $1191-92$.

104. A more general historical reason-rooted in our long "cultural hostility to taxation without representation," Winkfield F. Twyman, Jr., Losing Face bur Gammy Power" State Taxation of Interstate Commerce, 16 VA. TAX REV. 347, 383 (1997) (citing numerous sources)-also supports the traditional distinction between affirmative subsidies and tax programs accompanied by exemptuons for local business. As I have noted elsewhere:

It runs deep in the American marrow that tax laws are susceptuble to abuse when they disfavor those with no say in the political process. Indeed, it wis "laxjtion without representation' that in large measure accounted for the birth of the nation that the commeree clause seeks to hold together.

Coenen, supra note 22 , at 481 .

105. These "matters of substance" do not-at least in an immediate sense-reflect economic differences. Instead, as we soon shall see, they focus on properiy-dnven notions of conventional faimess and state autonomy, as well as on an elaborate cluster of political considerations. At the same tume, these considerations-particularly insofar as they concem polıtical dynamics-have much to do with "economic realities." Complete Auto Transit, Inc. v. Brady, 430 U S. 274, 279 (1977). The key point is that while any particular tax break and any particular subsidy. once put in place, will operate in much the same way. it is less likely that monetary subsidies will be adopted or retaned. As a result, according to the argument made here, the economic consequences of subsidies and tax breaks will differ greatly in the aggregate and do so in a way that renders subsidies less threatening to our unitary national market For this reason. it would be wrong - or at least a significant oversimplification-10 suggest that the "functional" differences between subsidies and tax breaks marshaled here are divoreed from pracueal economic concerns

It is also worth noting that this Aricle's focus on polttical process constderations does not reflect advocacy of a position in any debate about whether the dormani Commerce Clause promanly concems counteracting the political incapacities of "outsiders," see. $\mathrm{g}$. JOIN HART ELY. DEMOCRACY AND DISTRUST 83-84 (1980), advancing the realuty of an efficiency-entaneing economic unton, sec, $c \xi$ RICHARD A. POSNER, ECONOMIC ANALYSIS OF LAW 638-39 (th ed 1992), or achieving national politieal integration and harmony, see, e.g.. Regan, stupra note 4. at 1114 My own (prelsminary) sense is that each 
example, that "political communities ... have a prima facie justification for limiting distribution of their public goods to those who combine to provide them." 106 Others have argued that considerations of state autonomy reach their highest ebb when "a state's use of its own tangible resources" is at stake. ${ }^{107}$ These considerations, driven by policies of fairness and of federalism, have been developed and defended elsewhere, and shall be touched on again in due course. ${ }^{108}$ For now, it suffices to observe that, if these policies counsel relaxed application of the antidiscrimination principle in any setting, they do so in cases that involve outright payments of a state's own cash.

Even more important, the differences between outright subsidization and the grant of tax breaks reflect the ways in which voters and their representatives think and act. The existing literature touches on these political-

of these strands of thinking about the dormant Commerce Clause has a useful role to play and that these different points of emphasis are more mutually reinforcing than mutually exclusive. I also believe that the full argument advanced here readily comports with each of these overarching conceptions of the dormant Commerce Clause.

106. Varat, supra note 22, at 523; see also Truax v. Raich, 239 U.S. 33, 39-40 (1915) ("[D]istribution of the public domain, or of the common property or resources of the people of the State . . may be limited to its citizens as against ... the citizens of other States . . ."); USA Recycling, Inc. v. Town of Babylon, 66 F.3d 1272, 1288 (2d Cir. 1995) (refusing to invalidate a "subsidy" given to the town-hired waste hauler, by way of affording free access to the town incinerator, because such a plan involves "a local government spending tax dollars for the benefit of its citizens"); LAURENCE H. TRIBE, CONSTITUTIONAL CHOICES 145 (1985) (noting the "sense of faimess in allowing a community to retain the public benefits created by its own public investment"); Alexander, supra note 39, at 1007 ("If . . . subsidies . . . were unconstitutional, little sense would remain of the idea of separate states with particular concern for their own citizens' welfare."); Bair, supra note 22, at 2420 (referring to "the moral and political entitlement of state residents to the benefit of state funds"); Levmore, supra note 39, at 584 (citing the "failure of commerce clause objections to a state's expenditures in favor of its own citizens"); Earl M. Maltz, How Much Regulation Is Too Much-An Examination of Commerce Clause Jurisprudence, 50 GEO. WASH. L. REV. 47, 68 (1981) (" $A$ A]lthough some rights stem from residence in the United States as a nation, many others derive from residence in a particular state. Prominent among the latter is the right to receive largesse from the stato government.").

107. Anson \& Schenkkan, supra note 22, at 99 (concluding that "federalism demands a respect for state decisions of political economy that the Court never has accorded in traditional dormant Commerce Clause cases, a respect that the Court is institutionally ill-suited to reconcile with national economic concerns"); see Heinzerling, supra note 18, at 259 ("II]t does not seem an overstatement to say the very idea of a town or a county or a state ... would become incoherent if these units of government were not allowed to distinguish between insiders and outsiders in distributing government resources . . .."); Twyman, supra note 104, at 429 ("The most significant element [behind the market participant exception] secms to be ... the use of resources which belong to the state itself."); Wells \& Hellerstein, supra note 18, at 1130 ("Proprietary activity [may be] viewed as an exercise of state fiscal autonomy in spending its moncy ...." (emphasis omitted)); see also Gergen, supra note 22, at 1134 ("A rule prohibiting subsidies would be difficult to administer because of the problems in distinguishing preferences in the allocation of public services from subsidies that improve the position of a state's citizens in the market.").

108. See infra notes $343-355$ and accompanying text. For an elaboration of the fairness- and federalism-based arguments for state autonomy in resource distribution programs, see Coenen, supra note 22, at 421-30. In particular, for the reasons that state funds-including monies raised from out-of-staters through generally applicable taxes-may properly be deemed "owned" by and fairly returnable to only the state's own residents, see $i d$. at 425-26. 
process-based distinctions. ${ }^{109}$ Prior treatments, however, identify these differences in abbreviated-and therefore greatly understated-terms. ${ }^{10}$ In fact, a host of functional considerations suggest that subsidies in the aggregate do not threaten distortions of our "unitary national market" as much as discriminatory tax breaks."

First, a state's imposition of costs on its citizens is more visible when the state awards outright subsidies than when it doles out tax relief. "I It is sometimes said that subsidies pose a reduced risk of disrupting interstate markets because they are inherently expensive to pursue. ${ }^{113}$ This argument, however, is open to question because basic tax expenditure theory teaches that tax breaks and outright payments are functionally the same in this respect. ${ }^{114}$

109. Among the principal treatments of this topic are id. at 475. 480-81: Ennch. supra nolc 18. at 42 43; Gergen, supra note 22, at 1138; Hellerstein \& Coenen, supra note 27, at 846-47. Kline, supra note 22. at 370-91; and Regan, supra note 4, at 1194-97. See also Collıns, supra note 27. at 103

110. See, e.g., West Lynn Creamery. Inc. v. Healy, 512 U.S. 186. $211-12$ (1994) (Scalıa. J , concumng in the judgment) (noting, in one sentence, the possible political process distinction between affirmative subsidies and tax relief, but adding that this "is not . . . the basis for my position").

111. West Lynn Creameny, 512 U.S. at 193. It is possible, of course, that the distunctions deseribed here may prove to be of interest not only to lawyers. but also to those who work in the fields of economics. political science, state and local government, accountung, and busuness. Among the nonlegal matenals that I found especially illuminating are: CHRISTOPHER HOWARD. TIIE HIDDEX WELFARE STATE: TAX Expenditures and Social Policy in the UNITEd States (1997): Hermax B Leonard. Checks UNBALANCED: THE QUIET SIDE OF PUBLIC SPENDING (1986); SCHWENE ET AL.., supra nole 24; and Helen F. Ladd, The Tax Expenditure Concept After 25 Years, in NATIONal TAX Ass' $v$. 1994 Proctediscs of THE EIGHTY-SIXTH ANNUAL CONFERENCE ON TAXATION 50 (1994). Additıonal valuable matenals include: TAX EXPENDITURES AND GOVERNMENT POLICY (Neil Bruce ed., 1988): Karen M. Benker. Tax Expendurure Reporting: Closing the Loophole in State Budget Overstght. 39 NAT'L TAX J. 403 (1986): J.E. Harns \& S.A. Hicks, Tax Expenditure Reporting: The Uthlizarion of an Innos'ation. 12 PUB. BUDGETs \& FIN. 32 (1992); Ronald F. King. Tax Expenditures and Systematic Public Poltcy: An Essay on the Polutcal Economy of the Federal Revenue Code, 4 PUB. BuDGetiNg \& FiN. 1.4 (1994): Allen Schick. Controlling Nonconventional Expenditure: Tax Expendiures and Loans, 6 P(1B. BUDGETING \& FIS. 3 (1986). Aaron Wildavsky, Keeping Kosher: The Epistemology of Tax Expenditures. 5 J. P(1B. POL'Y +13 (1985). and Michael J. Wolkoff, The Nature of Propern, Tax Abatement Awards, 49 J. AN. PLAS Ass' 77 (1983) See also JAMES MOSES, STATE INVESTMENT INCENTIVES IN ThiE USA (The Economist Intelligence Unil Special Report No. 187, 1985); NORTHEAST MIDWEST INST. THE GUIDE TO STATE: A DD FEDERAL. RESOURCES FOR ECONOMIC DEVELOPMENT (Charles Bartsch el al. eds.. 1988): WILLAAM SCIWEKE ET AL. IMPROVING YOUR BUSINESS Climate: A GUIDE to SMARTER PLBLIC INVESTMENTS iv ECONONIC DEVELOPMENT (1996); Roben H. Gleason. Reevaluating the Califorma Sales Tax. Exemptions, Equalin. Effectiveness, and the Need for a Broader Base, 33 SAN DIEGO L. REV. 1681 (1996). Richard D Pornp. Siate Tax Expenditure Budgets-And Beyond, in THE UNFINISHED AGENDA FOR STATE TAX REFORM 65 (Steven D. Gold ed., 1988). The classic works on tax expenditure theory include STANiley S SLRREY \& PAUl R. MCDANiEl, TAX EXPENDITURES (1985); and Surtey, supra note 38

112. See Pelican Chapter, Associated Builders \& Contractors. Inc. v. Edwards, 901 F Supp 1125. 1137 (M.D. La. 1995) (recognizing that tax exemptions differ from subsidies because "an exemption assists the exempted enterprise passively" whereas subsıdies are subject to "heightened political visibility"); GEOFFREY R. STONE ET AL., CONSTITUTIONAL LAW 300 (20 ed. 1991) (noling the suggestion that outright subsidies have greater "political visibility"); Gergen, supra note 22. at $1111-12$ (distınguishung subsidies. which signal costs to the state, from measures "[whose] cost is hidden").

113. See Regan, supra note 4, at 1194; see also Varal. supra note 22. at 541 ("IMI)onelary resources are finite; making funds available for one purpose, or for one group. mahes them unavalable for use by another.").

114. See supra notes $36-38$ and accompany'ing text. 
A better formulation holds that it is easier for a legislator or a voter to see that a state is spending its money when it actually writes and sends out a check. ${ }^{115}$ And when state spending is more easily seen, it is more easily scrutinized, second-guessed, and blocked. ${ }^{116}$

Second, the extent of cost-no less than the fact of cost-is more readily perceptible when the state's support of local industry takes the form of a monetary subsidy. ${ }^{117}$ This is the case because the total amount of subsidy

115. See LEONARD, supra note 111 , at 108 ("Since no funds need be appropriated, tax subsidies secm less expensive."); $i d$. at 205 ("Public financing through the appropriations process . . . provides some sense of actual spending taking place."); SURREY \& MCDANIEL, supra note 111, at 105 ("The relative invisibility of tax expenditures inevitably causes many congressmen to think almost immediately of a tax response to a particular social, business, or other problem of concern to them."); Drahozal, supra note 33, at 1153-54 n.143 (describing the phenomenon of the relative transparency of subsidies as compared to tariffs or quotas); Enrich, supra note 18, at 395 ("[T]he costs of tax incentives remain largely invisible in the political process."); Surrey, supra note 38, at 721-22 ("[M]any tax incentives look, and are, highly irrational when phrased as direct expenditure programs structured the same way. Indeed, it is doubiful that most of our existing tax incentives would ever have been introduced, let alone accepted, if so structured, and many would be laughed out of Congress."). As one commentator observes:

If tax expenditures were administered as grants out of annually appropriated funds, they would quickly be subject to the same scrutiny as other grant programs. As soon as we started issuing actual checks, we would become more curious about whose names are on them. Disbursing real money has a way of galvanizing public attention.

LEONARD, supra note 111 , at 127.

116. See Ladd, supra note 111, at 53 ("[A]lthough many tax provisions function like spending programs, they are not subject to the same scrutiny as direct spending programs."); Neil Bruce, Pathways to Tax Expenditures: A Survey of Conceptual Issues and Controversies, in TAX EXPENDITURES AND GOVERNMENT POLICY 21, 45 (Neil Bruce ed., 1988) ("[T]he main difference between taxes and direct expenditures is the government processes involved in their approval and administration. As Leonard ... states, funds administered through the expenditure process are 'deliberated, approved, recorded and revealed." (quoting LEONARD, supra note 111)); see also LEONARD, supra note 111, at 147 ("State use of tax expenditures seems part of a general pattern described in the discussion of federal tax expenditures: when governments want to foster a public purpose, but do not want the exposure and scrutiny of the appropriations process, they turn to tax expenditure devices."). The low visibility of the "cost" of a tax break may be especially problematic when (as is often the case) the tax break is enacted contemporaneously with the tax to which it applies because the overall effect of such legislation is to raise revenue and thus reduce budget-balancing problems. See Levmore, supra note 39, at 584-85. Of course, as others have observed, "[s]ubsidies can be made less transparent." Drahozal, supra note 33, at 1153 n.142. For cxample. visibility concerns may well explain states' avoidance of "lump-sum payments" in favor of subsidization "based on the level of production" and "government loan programs." $/ d$. Professor Hellerstein and I have argued elsewhere that - while the costs of some subsidies (including forgivable loans) may have somewhat reduced visibility - this reality does not justify placing them in a separate category from ordinary subsidies. See Hellerstein \& Coenen, supra note 27, at 865-66.

117. See Drahozal, supra note 33, at 1153 ("[S]ubsidies, at least in their pure form, are more 'transparent' than tariffs-that is, their costs are more obvious to voters."); Enrich, supra note 18, at 396 ("Indeed, because many tax breaks focus on new or expanded business activity, their advocates commonly argue that the incentives entail no loss of revenue at all, for in the absence of the incentives, the businesses that receive the tax breaks would have located elsewhere and the state revenues foregone by the incentives never would have been available in the first place."); $i d$. at 443 ("[Tax breaks] are less politically visible-indeed, their actual costs are often unknown...."); Kline, supra note 22, at 374 n.202 ("[S]pending . . . generates a direct cost to the state visible to the state legislature."). One observer notes:

A subsidy financed by tax revenue and hence going through the budget makes it obvious that an industry is protected. A clear sum of money stands witness to the cost .... By contrast, ... [q]uite elaborate research may be needed to calculate the subsidy-cquivalent of the tariff . . . . For this very reason free-trade-minded economists preferred subsidies to tariffs long 
payments can be determined through the easy means of tallying total payments by the state. Moreover, "with a subsidy, there is a state budget item that precisely quantifies the amount paid to domestic producers," and "[t]hat information is simply and cheaply available."118 In contrast, tax expenditures are made "passively" - not through the outright expenditure of state funds, but (at least usually) through claims made by taxpayers on their tax returns."19 While "tax expenditure budgets" are theoretically constructable, they seem not to work well in practice. ${ }^{120}$ As a consequence, discriminatory tax breaks pose a heightened risk to Commerce Clause values because "their actual costs are often unknown."121

before the theory of domestic distortions was developed The chances of sustaned protection are certainly less with subsidies.

W. MAX CORDEN, TRADE POLICY AND ECONOMIC WARFARE 56 (1974).

118. Drahozal, supra note 33. at 1153: see also LeONARD. supra note 111. at 121 (notung that. in contrast to tax expenditures, "[n]o . . ambiguity anses in defining direct outlays; a dollar of spending is relatively easy to define").

119. See Walz v. Tax Comm'n, 397 U.S. 664.690 (1970) (Brennan. J . concumngl. HowsRD, supru note 111, at 16 ("[T]ax expenditures leave a fanter paper tral than comparable direct spending programs; . . . their low profile can be a decided advanlage for the programs" adiocales "). Ladd. suprot note 111 , at 52 ("[W]hen tax provisions lead to taxes not beng collected. nothing is taken from indusuduals. and therefore there is nothing to account for."): see also Wolhoff. supra note 111. 31 79 ("Tax abatements contain elements that make implementation easy. For example. benefits appear to be realized without cost."). Another commentator adds:

When a program is delivered through the tax system. however. unlihe a direct spending program, it cannot be monitored on an on-going basis. Even the most basic infornation about tax expenditures must be obtained from tax retums and is nomilly not avalable untul over a year and a half after the program is first enacted.

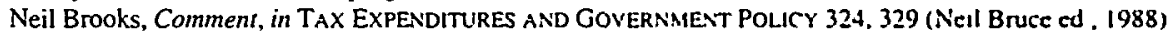

120. See SCHWEKE ET AL., supra note 24, al 21 (noung that very few states hale useful "tax expenditure budgets"); Richard M. Bird, Comment, in TAX EXPENDIT'RES AND GoversMENT POL.ICY 123. 123 (Neil Bruce ed., 1988) ("[A]s many of the papers at this conference show. any particular set of [tax expenditure budget] numbers is always open to altack and. even worse. misuse. In this respect at least. tax expenditure analysis still remains in the 'twilight zone' ... .): Thomas $S$ Neubig. The Current Role of the Tax Expenditures Budget in U.S. Policymaking. II TAX EXPENDITURES AND GOVERSUENT POLCY 239, 243 (Neil Bruce ed., 1988) ("[T]he current [federal] tax expenditure budget is verued, correctly, as having conceptual and measurement problems which render 11 both pracucally and politically difficult to play a larger role in public policy debate."); Wildavsky. supra note III, at $\$ 20-25$ (detauling difficulies of constructing useful tax expenditure budgets). One commentator concludes.

The tax expenditure budget (TEB) has figured in congressional debates about tax reform. and it may have helped to limit expansion and reduce the scale of some tax expenditures But the tax expenditure device has shown itself to be remarhably robust Most of the tax expenditures listed in the original TEB are still in force. Revenue losses contunue to increase LEONARD, supra note 111 , at 110-11. He adds that "[f]Ifly tax expenditure :tems were listed in the tirst TEB; there are now more than twice that many. The introduction of TEBs does not appear to have alicted the historical trajectory of tax expenditure spending." $l d$. at 117. see also infra notes 1+6-1.99 and accompanying text.

121. Enrich, supra note 18, at 443; see also LEOVARD. supra nole 111. at 107 ("IT]ax breaks do theit best work in the dark. When governments support activitues by ussuing checks. it is usually easy lo identify the activity, the recipient, and the amount of suppon. All three are in doubt when the suppon comes through tax breaks."); id. at 129 ("Because tax expenditure spending is intangible (how much more revenue would we have in the absence of subsidies?), It has an ethereal character . . . You can'l see or smell or feel it the way you can real money, and so " remains easier to spend than real money "). SCHWEKE ET AL. supra note 24, at 67 ("Reductions in taxes or tax rates that are used to influence business decistons are 
Third, tax credits, exemptions, and the like are resistant to repeal because legislatures typically enact them as presumptively permanent features of state tax codes. ${ }^{122}$ In contrast, because subsidies involve the direct expenditure of funds, they routinely show up-and are subject to recurring reevaluation-as expense items in perennially controversial state budget bills. ${ }^{123}$ As a result, in each legislative session, the subsidized industry must compete with every other interest group in the state to retain its piece of the appropriations pie. ${ }^{124}$ This continuing structural vulnerability to elimination distinguishes the monetary subsidy from the ordinary tax break. ${ }^{125}$

analogous to spending programs or subsidies ... . But, unlike direct expenditures, the value of tax expenditures is not always compiled and disclosed to the public."); Enrich, sipra note 18, at 395-96 ("Forecasts both of the foregone revenues from business tax incentives and of their countervailing economic benefits (with their derivative revenue gains) are notoriously open to debate; as a result, decisionmakers can freely espouse estimates that minimize the costs and maximize the benefits of such incentives.").

122. See Pelican Chapter, Associated Builders \& Contractors, Inc. v. Edwards, 901 F. Supp. 1125 , 1137 (M.D. La. 1995) (noting that "[t]ax laws are generally effective until repealed," whereas subsidies are regularly reevaluated); Enrich, supra note 18, at 395 ("[Tax laws] are typically adopted through a process independent of the appropriation machinery, and they ordinarily do not require annual re-authorization, as direct budgetary outlays do."); id. at 443 (emphasizing that tax breaks typically become "a standing part of the tax code"); Ladd, supra note 111, at 55 (noting that "because they are still typically treated more like provisions of the tax code than like direct expenditures, [tax breaks] continue to be harder to cut than direct spending" and that experience at the federal level has shown that "most tax expenditures . . . are here to stay"); Schick, supra note 111, at 111 (noting that "[m]any [tax breaks] are established in permanent legislation and continue in effect without new budget decisions" and that therefore they "often do not undergo regular budgetary or legislative review"); see also Gleason, supra note 111, at 1703 n.98 (noting that in California "fewer than 15\% of all existing tax expenditures have "sunset' provisions"); $c$. Guido Calabresi, The Supreme Court, 1990 Term-Foreword: Antidiscrimination and Constitutional Accountability (What the Bork-Brennan Debate Ignores), 105 HARV. L. REV. 80, 104 (1991) (discussing inertia that results in legislatures' "often . . . failing to repeal old laws").

123. See Coenen, supra note 22 , at 481 (noting that "the annual revisitation of legislated subsidies should assure that the state interest supporting the program remains a keen one," while exemptions lack such visibility); Drahozal, supra note 33, at 1155-56 ("[A] subsidy is a less durable form of protection than a tariff. Subsidies must be appropriated by the state legislature on an annual basis. Thus, subsidies require ongoing lobbying by protected industries in order to assure that protection continues. Conversely, tariffs are not automatically revisited on a year-to-year basis. Once a tariff is enacted, it continues to protect the industry until affirmatively repealed ...."); Kline, supra note 22, at 374 ("State subsidics... are dependent upon the renewed grace of the local legislature, city, or town council for their continuance. As such, they are visible, direct, and recurring costs to the state checked through both the political process and the state budget." (footnotes omitted)); Pomp, supra note 111, at 66 (discussing a 1969 New York investment tax credit, which generated more than $\$ 660$ million in credits before being restudied, and stating that for 16 years the credit "received less review and analysis than did explicit spending programs that cost a million dollars or less"); see also Surrey, supra note 38, at 725 (citing the "lack of an explicit accounting in the federal budget for the tax expenditures involved in tax incentives"); $i d$. at 730 ("[T]ax incentives are not covered by the annual budgetary review process.").

124. See Enrich, supra note 18, at 395 ("Because tax breaks involve a reduction of public revenucs, rather than an expenditure of public funds, they do not directly compete with other programs demanding scarce governmental resources."); id. at $395 \mathrm{n} .91$ ("These same considerations also enhance the appeal of tax incentive methodologies for business advocates, because such measures simplify the legislative process and obviate the need to fight the same battles each year.").

125. See LEONARD, supra note 111 , at 108 ("[T]ax expenditures are shielded from review. The tax code is not revised every year; once a tax preference has been established, it does not require reauthorization and new appropriations, as do direct expenditure programs."); SURREY \& MCDANIEL, supra note 111, at 107 (observing that "tax expenditures are more securely embedded than direct programs and 
Fourth, discriminatory tax breaks are more likely to damage our unitary economy because they have an open-ended, unrestricted quality. ${ }^{126}$ Subsidy funds may simply run out, and subsidy programs at least will be scrutinized with great care in the next budget cycle if cost overruns occur. ${ }^{127}$ In contrast, discriminatory tax expenditures are not subject to any comparable empty cookie jar effect. ${ }^{128}$ Indeed, once in place, they may quickly grow through incremental, and unnoticed, accretion. ${ }^{129}$

thus will remain in effect considerably longer"); Bruce, supra note 116, at 45 (noting that "provistons in the tax law are not subject to periodic review in the same way that expenditures are"): Ennch, supra note 18, at 443 ("[Tax breaks] do not have to compete with other demands on state resources in the appropriation process."); Gleason, supra note 111, at 1703 (“[Tax expenditures] weaken the Legislalure's control over the budget because, once passed, they are no longer par of the nomal annual appropnations process."). Gleason observes:

Professor Bittker quotes Walter Heller in observing that tax subsidies might be polstically more palatable than direct expenditures and, moreover, that such subsidies, once granted. are difficult to remove: . . . " $[\mathrm{H}]$ ere is a whole catacombs of Government benefits which are largely hidden from public view, let alone, periodic review. Once imbedded in the tax structure. the preferentual provisions are treated as inalienable vested rights, impervious to changes in tax rales. economic policy, and technology."

Gleason, supra note 111, at 1703 n.98 (quoting Boris 1. Bittker. Accoumung for Federal "Tax Subsidies" in the National Budget, 22 NAT'L TAX J. 244 (1969)): of. Surrey. supra note 38. at 738 (arguing that, in light of this traditional difference in treatment. "new tax incenuve programs. if any are to be adopted. should have a time limit set on their operation . . to permit evaluation of . . effectiveness"). As Ladd points out:

State-specific rules may compound the inertia associated with tax-break appeals. For example Even greater barriers exist in some states, as is illustrated by Califorma. In that state, tax increases require a $2 / 3$ favorable vote. Hence, because a reduction in tax expenditures is trealed as an increase in taxes rather than a cut in spending, it ts harder to cut tax expenditures than it is to cut direct spending. This $2 / 3$ requirement plus other charactenstics of tax expenditures have meant that during recessions and periods of budget deficits. the system is biased loward cuts in direct spending and away from cuts in tax expenditures.

Ladd, supra note 111 , at 55 .

126. See, e.g., LEONARD, supra note 111 , at 108 (“(T)ax expenditures are entutlement programs. all qualified applicants are granted benefits without reference to any celing."); SCHWEKE ET $\lambda$ L. supra note 24, at 21 (noting that "tax incentives ... are not typical expenditures with a predetermined budget" and that the "amount of these tax expenditures, then, cannot be predicted beforehand"): Surrey. supra note 38 , at 726 ("Tax incentives are usually open-ended: they place no limut on how much tax benefil a taxpayer can earn. Hence it is difficult to foretell how much will be spent by the Government through a particular incentive.").

127. See Bair, supra note 22, at 2422 (citing "built-in restrants" on resident contractual preference laws).

128. See Enrich, supra note 18 , at 443 ("[The] magnutude [of tax incentives] is not typically fixed by the legislature, like the cast of ordinary government programs. but rather is determined by the extent to which taxpayers make use of them."); Surrey, supra note 38. at 730 ("[W]hen overall expenditure limits are directed by the Congress or when the President decides to cut expenditures it is essentially impossible to apply the restrictions to tax incentives. So far none of the vanous expenditure control devices. have in any way affected tax expenditures.").

129. See HOWARD, supra note 111, at 183 ("As students of tax policy are well aware, tax expenditures function like budgetary entitlements: once embedded in the tax code, these programs can grow without any subsequent changes to eligibility criteria or benefit levels."): Gleason. supro note 111. at 1704 ("iT]here is no cap on the amount of foregone revenue created by enactment or contınuance of (a tax expenditure]." ): Ladd, supra note 111 , at 55 ("Like entitlement programs, growth in tax expenditures caused by increases in the favored activity is not subject to pay-as-you-go provisions."); see also Schick. supra note 111 . at 11 ("[T]ax expenditures are . . . similar to entitlements. They . . . tend to be open-ended. with costs nsing in 
Fifth, monetary subsidies differ from tax breaks because subsidy programs are usually more costly for the state to administer. ${ }^{130}$ From this perspective, a major attraction of tax breaks is their method of operation: As a rule, persons eligible for credits, exemptions, or deductions simply claim them on regularly submitted returns, thereby reducing their own tax bills. ${ }^{131}$ The establishment of a subsidy program, in contrast, requires the creation of an administrative machinery to handle funds and records and to make determinations as to

step with changes in exogenous conditions."). For an example of one tax expenditure that has experienced invisible or unchecked growth, see HowarD, supra note 111, at 94. As Howard notes: "For most of its history the home mortgage interest deduction experienced growth without advocacy. The program has become somewhat more visible and politicized since then, but advocates still do not have to alter its structure in order to produce growth." Id. Another commentator observes:

The volume of [business development tax] abatement activity has increased markedly. In New

York City, the amount of abated tax dollars now totals, after four years, over $\$ 4,000,000$. . .

What is most interesting about this tremendous expansion of abatement awards is the apparent ignorance with which they are made. It appears that once a locality decides to offer property tax abatements, there are few conditions when awards are not made.

Wolkoff, supra note 111 , at 78 (citations omitted).

130. See JoInt ECON. COMm., 91st CONG., 1969 Joint ECONOMIC REPORT, H.R. ReP. No. 91-142, at 20 n.* (noting that "tax incentives . . . can eliminate the need for additional bureaucratic apparatus"); see also LEONARD, supra note 111 , at 108 ("One view is that tax expenditures are used because they can be precisely targeted and administered at low cost-that is, because they are efficient subsidics."); King, supra note 111, at 26 ("Administratively, such tax expenditures permit speedy implementation, with little additional paperwork and without the expansion of what is often viewed as a prying bureaucracy."); Ladd. supra note 111 , at 54 ("IT]he absence of red tape often gives tax expenditures administrative advantages over direct subsidies, and the tax system provides a prompt and efficient mechanism for informing potential applicants of relevant government programs, such as broad-based business incentive programs.").

131. For instance, one prominent legislator introduced a tax expenditure bill with the comments: The advantages to a tax credit approach are numerous. The most important, however, is that the program can go into effect immediately upon enactment. . . . This is an uncomplicated program with the minimum of red tape. ... This bill would require no Federal appropriations. ... The most convenient form for subsidizing a businessman is through his income tax.

115 CONG. REC. 12,876 (1969) (statement of Sen. Percy). Howard concurs:

By working through the tax code, the [tax expenditure] eliminates the need for large social service bureaucracies. It requires seemingly small changes to established tax forms and existing procedures of tax collection. The program is largely self-executing: individuals determine their own eligibility and calculate their own benefits based on simple instructions accompanying the annual tax return.

HOWARD, supra note 111, at 140; see also LEONARD, supra note 111, at 107-08 ("[T]axpayers . . claim their subsidies through tax returns. . . . Tax-subsidized programs largely administer themselves.”). Or as another commentator puts it:

Most direct expenditure programs are administered so as to verify potential claimants' cligibility for benefits before granting those benefits. Conversely, most tax expenditure programs check for eligibility only on an ex post basis, after the claimants have undertaken the specified activity or expenditure and made their claim. For most tax expenditures these checks arise only where documentary evidence is required with the tax return or where individuals are audited. The majority of tax expenditure claimants are never checked at all.

Jonathan R. Kesselman, Direct Expenditures Versus Tax Expenditures for Economic and Social Policy, in TAX EXPENDITUREs AND GOVERnMENT POLICY, 283, 299 (Neil Bruce ed., 1988); see also Stanley L. Winer \& Walter Hettich, Tax Expenditures and the Democratic Process, in TAX EXPENDITURES AND GOVERNMENT POLICY 379, 389 (Neil Bruce ed., 1988) ("The tax deduction or credit route may also save on auditing costs by making use of existing auditing processes in the tax system."). 
eligibility and amounts. ${ }^{132}$ At first blush. this point may suggest that tax expenditures are more efficient, and thus more defensible, than outright monetary subsidies. The Constitution, however, is not a charter of economic efficiency, particularly with respect to the intentionally checked and balanced internal workings of government. ${ }^{13}$ Moreover, insofar as the dormant Commerce Clause restrains state power to interfere with private markets, its purpose is not so much to advance economic efficiency per $\mathrm{se}^{13 \mathrm{t}}$ as to safeguard economic and political union. ${ }^{135}$ From this vantage point, the

132. See, e.g., Camps Newfound/Owatonna. Inc. Town of Hamson, $117 \mathrm{~S}$ Ct 1590, 1605 n 23 (1997) ("'. $[A]$ direct money subsidy . . could encompass sustauned and detalled admunistratue relationships ...." (quoting Walz v. Tax Comm'n. 397 U'.S 664. 675 (1970))). SL RREY \& MCDA YIEL. supra note 111, at 108 ("Proponents of tax expenditures regard the Internal Revenue Sentec as an effeeure administrative mechanism already in place to be utilized. Unlihe the alternatuse case involung a direct program, there is thus no need to establish a new process of admunistratıon. perthaps a new agency "). Drahozal, supra note 33, at 1150 ("Tariffs and subsidies have other costs as well For example, tanffs must be collected and subsidies must be disbursed. These admmistratue cosis are probably lower for a tanff because tariffs have no disbursement cosis ....). Kesselman. supra nole 131. at 315 ("The exustung tax systems offer a ready-made administratuve and complance mechamism for business incentuses There is no need to establish an entire parallel bureaucracy for promotion. claums processing. payment, auditıng. and enforcement, as would be required by a direct expenditure program of busuness incentues "). Aeubig. supra note 120, at 249 ("The spector [sic] of the Department of Housing and L'ras Development administenng a mongage interest subsidy program for the mudle-class is not considered stmpler than the cument mortgage interest deduction."): see also Tumer Broad. Sys. Inc 、 FCC. 117 S Cl 1174. 1202 11997) (rejecting the argument that subsidies for broadcast stations constutute a less restnctive altematue to must. carry requirements imposed on cable systems and reasoning that a subssdy system "would require the Government... to establish a potentrally elaborate admonistratuce structure to make subsidy determinations"). Surrey, however, argues:

It is not the tax route that makes the program sumple-it is a substantuse decision to have a simple program. In many cases. It is true, direct expenditure programs are probably overstructured and the urging of tax incentives is a reaction to. and a ialid criticism of. badly designed expenditure programs. The cure hes of course in better designed expenditure programs Surrey, supra note 38 . at 717.

133. See, e.g., INS v. Chadha, 462 U.S. 919.944 (1983) (statting that "|c|onsenience and efficiency are not the primary objectives-or the hallmarhs-of democrauc government"). Henn M. Han. Jr. The Relations Between State and Federal Law, 54 Cot.t 1. L. REV $499.490-91$ (1954) (notung that the premse of the federal system is that the complexity and inefficiency it produces are justified by countervalung values).

134. See CTS Corp. v. Dynamics Corp. of Am. 481 L'.S. 69.92 (1987) ('The Consutution does not require the States to subscribe to any particular economic theon "). Anson \& Schenhtan. supra note 22. at $78 \mathrm{n} .31$ ("The assumption that the commerce clause embodies a free (rade balue is erroneous "), Kline, supra note 22, at 356 (rejecting "economic efficienc)" as "a "core" constitutional salue" underlying the dormant Commerce Clause): Regan. supra note 4. at 1116 (assertung that "There is no constututional interest" in efficiency to the extent it is meant to describe "low prices or high production"). ud at 1124 ("The people who wrote our Constitution were by no means thoroughgoing free traders"). id at 1130 ("[S]tates are not required to legislate only in ways that would be approved by a committe of theoretical welfare economists . . . "): Wells \& Hellerstein, supra note 18. at 1126 ("-[E]conomic efficiency, how ever desirable, is not a criterion of constitutionality under the commerec clause."). of Regan, supra note 4, at 1234 (noting that in Exxon Corp. v: Governor of Manland. 437 L'S 117 (1978), the "Coun upheld the statute even though it may well have caused significant inefficiency in gasoline distnbution in retum for very slight benefits").

135. See H.P. Hood \& Sons צ. Du Mond. 336 U' S 525, 533-.35 (1949) (statung that the Framers designed the Commerce Clause to promote "solidanty" and "the peace and safety of the Unon"). Kline. supra note 22, at 356 (citing the "goal of natuonal unificatıon"). Regan, supra note 4. at 1115 n 55 (noung that "the framers were womied about commercial nisaln as a threal to the polutical viability of the new 
greater administrative costs associated with subsidy programs should tend to discourage their adoption and retention by the states in comparison to less costly tax breaks. Given the goals of the dormant Commerce Clause, the constitutional ban is thus logically targeted at the more politically appealing discriminatory tax break, rather than at the less appealing monetary subsidy.

Sixth, cash subsidies are less likely than discriminatory tax breaks to take hold and to persist because most people view tax structures (especially tax structures applicable to corporations and other businesses) as an esoteric specialty beyond their capability and willingness to understand. ${ }^{136} \mathrm{~A}$ failure to understand breeds a failure to second-guess, and a failure to second-guess implies that tax structures will, more readily than monetary subsidies, escape political opposition.

Finally, a variety of psychological reasons-rooted in the general desire for tax relief and a heightened attentiveness to how one's "own" money is spent-suggest that citizens may well be more inclined to look the other way when legislators enact a tax break than when they adopt an affirmative monetary subsidy with comparable economic effects. ${ }^{137}$ In particular, tax breaks are more likely to gain acceptance because citizens do not perceive them as taking away that which those citizens see as already being their own ${ }^{138}$ or as channeling scarce state funds to competing (but no more

union" (citing THE FEDERALIST Nos. 6, 7 (Alexander Hamilton))).

136. See EDWARD J. MCCAFERY, TAXING WOMEN 267 (1997) (noting "how distant and alienating the facts of tax seem to most people" and observing that "Americans have trouble filling out their own tax forms"); SURREY \& MCDANIEL, supra note 111 , at 70 (noting "the complexity of the tax system as a whole"); Winer \& Hettich, supra note 131, at 395 ("[T]ax structures are inherently complex and thus difficult to understand."). As Professor Surrey observes: "[T] he tax system is complex enough as it is, and to have a large number of tax incentives side by side with the provisions making up the structure of the tax itself can only cause confusion and a blurring of concepts and objectives." Surrey, supra note 38, at 731. Surrey continues:

It may be that legislators and the beneficiaries of tax incentive programs-businesses receiving accelerated depreciation or percentage depletion, state and local governments receiving tax exemption on their bonds-fear that once the public is fully aware of the amounts involved and can weigh expenditure costs against benefits received by the nation, the tax incentives will be found wanting in many respects. In this view, the deeper the incentive is buried in tax technicalities and tax terminology, the more it looks like any other technical tax provision, the more it partakes of the protective coloration of the tax law that can be obtained by such outward similarity to ordinary tax provisions, then the more desirable the tax incentive becomes.

Id. at 733-34.

137. See Surrey, supra note 38 , at 715 ("It is often said that a tax incentive is more uscful than a direct expenditure because people do not like ... 'subsidies."'). One commentator reflects that it can be expected that free individuals who form a compact to create a government with the power to command resources from them will, in turn, demand accountability as to how those resources are used. It is less obvious, to me at least, that they will demand the same sort of accounting for resources that are not taken from them due to tax expenditures.

Bruce, supra note 116 , at 46.

138. As Schick notes:

Although progress has been made in measuring tax expenditures, generally they are not perceived by the public or government as equivalents of direct spending. Insofar as they are regarded as the retained earnings or wealth of taxpayers, it is understandable that tax 
deserving) claimants. ${ }^{139}$ In addition, tax breaks may present a greater danger to the goal of discrimination-free interstate trade because many people view the proper "baseline" as a world in which governments engage in the most minimal level of taxation. ${ }^{140}$ On this view, tax breaks, more than subsidies, accord with the perceived and preferred norm; indeed, subsidies become suspect precisely because taxes are required to fund them. ${ }^{141}$ In a similar vein, subsidies may be looked upon unfavorably because they are symptomatic of large and meddlesome government, while tax exemptions seem to comport with limited government and the value of private initiative. ${ }^{142}$ Non-

expenditures have not been subjected to the same measure of conirol as is commonly applied to direct spending.

Schick, supra note 111 , at 12. Or as Wolkoff argues:

Since property tax abatements involve no budget allocation. local officials can suppon these programs without visibly diverting funds from any group currently being supported. Tax expenditures shield local officials from the political conflict that would be generated if abatement awards were made at the expense of currently funded groups. This gives tax abatements a distinct advantage over other economic development insentuves that involve direc: transfer of funds to investing firms.

Wolkoff, supra note 111 , at 79 (footnote omitted).

139. See alan Stone. Regulation and Its Alternatives 12 (1982) (noung that a common response to subsidy proposals is for other groups to demand subsidies).

140. See, e.g., Self-Governing Americans. ECONOMIST. Dec. 21. 1996, at 29 30-3! (describing the historical American antipathy to taxation).

141. As a recent commentary on proposed federal tax reforms stated:

If Washington wants to subsidize higher education. Iet it set up a program of grants and scholarships. If it wants to reward capital gains, let it send chocks to sellers of stocks.

Neither proposal would ever fly, of course. Each would be attacked as a new government program in a downsizing era. Politicaliy, it is safer to tonure the tax code to accomplish the same things and label the result a tax cut.

Avrum D. Lank, Tax Masters Find More Ways To Make Things Complicaled. MillwaUkEE J. SENTINel. July 1, 1997, at ID; see also LEONARD, supra note 111. at 147 ("[D]ollars flowing through the appropriations process feel expensive.").

142. Consider in this regard the observation of Alexis de Tocqueville: The inhabitant of the United States leams from birth that he must rely on himself to combat the ills and trals of life: he is restless and defiant in his outlook toward the authority of sociely and appeals to its power only when he cannot do without it." ALEXIS DE TOCQUEVILLE, DEMOCRACY IN AMERICA (J.P. Mayer \& Mlax Lemer eds. \& George Lawrence trans., 1966) (1835); see also SURREY \& MCDANIEL, supra note III. at 107 ("Business generally dislikes the idea of government subsidies, with its implication that the pnvate sector is incapable of performing on its own. Tax expenditures, which business does not view as subsidies, carry no such negalive psychological effect."); id. at 104 (noting that "tax expenditure provisions [appeal to] public pereepuons of tax spending; legislators or presidents who do not want to appear to be 'big spenders' can comfortably approve tax expenditures without damaging their image of fiscal conservatism." (footnote omitted)): Brooks, supra note 119, at 328 ("[N]o moral opprobrium attaches in most social circles to tax avotdance."): Kung. supra note 111, at 16 ("In those cases where the federal government wants to subsidize a seemungly good thing but is uneasy about the entailed interference with the provic sector. "consistenily tums to the taxation mechanism, resolving its ideological dilemma through reliance on a means that appears least intrusive because it is based upon reduced public extractions from pnvate camings."). King adds

[W] hen the perceived need for public support conflicts with the belief in pnvate inutuatuve. government regularly turns to indirect vehicles which cloak its interventionism and make its dominion less obvious. Conceptually, tax expenditures can be portrayed as retuming funds to the private sector, making reduced govemment extractions appear as reduced govemment intrusion. 
beneficiaries of tax breaks may even tend to accept them on the view that, in the longer term, they might get tax relief too. In short, for a variety of psychological reasons, there is generally less risk of political opposition to discriminatory tax breaks than there is risk of opposition to discriminatory subsidies. ${ }^{143}$

It is impossible to offer strict empirical proof that the differences between tax breaks and subsidies catalogued here have significant real world effects. There are, however, several good reasons to believe that such effects exist. For example, since the mid-1970s, the federal government and a growing number of states have chosen to produce tax expenditure budgets. ${ }^{144} \mathrm{~A}$ number of factors may have inspired this movement, but the most significant factor seems obvious: Responsible officials, well-informed about how government decisionmaking works, saw a need to put "underhanded" tax-based spending on more of a level playing field with outright cash appropriations. ${ }^{145}$ It also is telling that once tax expenditure budgets were put in place, they appeared to have little effect. ${ }^{146}$ Again, various explanations for this outcome are

Id. at 26; $c f$. Heinzerling, supra note 18, at $271 \mathrm{n} .258$ (noting that some "defend free trade generally on the ground that it limits governmental power").

143. For some additional observations along these lines, see Ladd, supra note 111, at 54, which states that "tax expenditures are often popular because they resolve the conflict between the liberals' desire to have the government do something and conservatives' inherent belief in the market mechanism." Howard similarly notes:

Perhaps the more important attribute of tax expenditures is their ambiguity. Tax expenditures can be defended politically on at least four distinct grounds: as aid to some needy category of citizens; as a subsidy to third-party providers in the private sector, who furnish most of the goods and services underwritten by the tax code; as tax reductions; and as alternatives to traditional government programs (i.e., direct expenditures and regulation). These various objectives are not mutually exclusive. Policy makers can and do support tax expenditures for more than one reason. Such ambiguity helps proponents of new tax expenditures forge broader coalitions of support than proponents of direct expenditures are typically able to do. In particular, such ambiguity helps conservative Democrats and moderate Republicans to support tax expenditures more strongly than they do direct expenditures.

HOWARD, supra note 111 , at 11 (footnote omitted).

144. See Ladd, supra note 111, at 50-51 ("'Stanley] Surrey, in his capacity as Assistant Secretary of the Treasury, produced the first tax expenditure 'budget' or listing of [tax expenditure] provisions in 1968. The requirement that federal tax expenditures be lifted and published annually was subsequently enshrined in the Budget Control and Improvement Act of 1974."); id. at 52 (noting that "17 states have relatively comprehensive tax expenditure reports ... [and] 13 states have reports that are partial or are produced intermittently"); Harris \& Hicks, supra note 111 , at 33 ("Wisconsin and California issued the first tax expenditure reports in 1975 and 1976, respectively. The periodic issuance of tax expenditure reports by twenty-one states demonstrates a steady trend toward the production of this type of cost information." (footnote omitted)).

145. See, e.g., Wildavsky, supra note 111 , at 415 ("Opponents of tax expenditures are not opposed to subsidies per se. Many are proponents of increased spending on social welfare programs and would be delighted to see such subsidies grow. It is just that these expenditures should be above-board (i.e., manifest), not underhanded (i.e., latent).").

146. See, e.g. Harris \& Hicks, supra note 111, at 36 ("George Deukemejian, formerly the governor of California, recommended the termination of [tax expenditure] reporting because, 'the report seems to have little impact ....'”); Pomp, supra note 111, at 67 ("What evidence exists, albeit tentative, suggests that state tax expenditure budgets have not yet had any serious impact on the legislative process. A report 
available. ${ }^{147}$ One likely explanation, however, is that the same political dynamics that produced a perceived need for tax expenditure budgets in the first place (e.g., reduced visibility, heightened entrenchment, and psychological attractiveness) continued to push policymakers to favor tax breaks over outright spending even after those budgets were adopted. ${ }^{148}$ There is, however, an even more significant piece of evidence that political realities cause lawmakers to favor business-benefitting tax breaks over outright cash subsidization programs: In the real world, state tax-based business incentives are pervasive, while outright cash subsidies are uncommon. ${ }^{149}$ To put the matter bluntly, the

prepared by the National Conference of State Legislatures concluded that "tax expenditure budgets are unlikely to produce any meaningful policy changes except under special circumstances.'” (quoung STEVEN Gold \& Dale Nesbary, STATE TAX EXPENDITURE Review MEChanisms 16 (National Conference of State Legislarures Legislative Finance Paper No. 47, 1985)): Schuck, supra note 111, at 12 ("The U.S. budget classifies tax expenditures into the same functional categones that are used for direct spending. Thus far, however, few explicit tradeoffs have been made between the (wo types of expenditures."). Another commentator observes:

A review of the evidence suggests that Surrey's aspirations for tax expenditure analysis as a tool of tax reform have not been met. One circumstantial pioce of evidence is the growth in U S. tax expenditures [notwithstanding implementation of a tax expenditure budget] and. in particular. the new tax expenditures that were included in the 1981 Tax Act.

Ladd, supra note 111 , at 53 . She continues:

In its 1983-84 repor, the Califomia Deparment of Finance recommended climinatung the 10 year-old requirement to report tax expenditures. The first reason they ciled was that the legislature had ignored over 90 percent of the recommendations for repeal of specific tax expenditures made by the Deparment over the previous 10 years and that special interest groups had continued to be effective in securing the enactment of new tax expendstures. . The report cited nearly one hundred new tax expenditures and extensions of existing tax expenditures since 1972. Although the legislature responded by setting up legislatuve structures and procedures for regular review of tax expenditures, it still remains difficult in Calıforna to reduce or elimenate them.

ld. at 54; see also HOWARD, supra note 111, at 6 (noting "The impressive growth of tax expenditures over the past quarter of a century"); Benker. supra note 111. at 405 ("The dollar amount of revenue foregone due to tax expenditures has dramatically increased in recent years.").

147. See, e.g., LEONARD, supra note 111, at 121 (“Ambiguous-or at least debatable-conceptual underpinnings are not the only weakness of the [tax expenditure budget] device. It is also technically difficult to estimate the required figures and even to determine which figures to estımale."): Benker. supra note 111 , at 413 (discussing problems with gathenng information for tax expenditure reports): Hams \& Hicks, supra note 111 , at 35 ("The weakness of source data is a persistent problem in estimaling certain tax expenditure costs. It is seldom possible to compare estumated cost to actual cost because no actual cost referent may exist.").

148. See HowARD, supra note 111, at 189 ("[T]ax expenditures are segregated from direct expenditures in the budget process and budget documents. making informed trade-ofts among spending priorities harder to achieve."); LEONARD, sıpra note 111. at 126 ("Tax expenditures do not require appropriations and do not have to fit under expenditure cellings set early in the budget process. Whatever the [tax expenditure budget]'s virnues as an informational device. this reality virtually guarantees that tax expenditures will not be scrutinized as meticulously as direct expenditures."): see also Harns \& Hicks. supra note 111, at 45 ("[T] ax expenditure report information appears to be least accepted for the purpose for which it is most commonly advocated-consideration of the resourec allocation effeet of budget policy."); Neubig, supra note 120, at 249 ("The tax expenditure budget has become a revenue estumators" exercise and issue, rather than an economic. legal, budget. or polıcy issue. Unul the political leadership in the Executive and Legislative branches see the tax expenditure budget as a useful policy tool for their goals. it will not be used.").

149. See LeONARD, supra note 111 , at 142-43 ("In spitc of repeated analyses showing little impact 
proof is in the pudding. And the proof suggests that the array of political considerations detailed above render tax breaks that favor local businesses far more attractive to state policymakers than economically equivalent cash awards.

This lengthy listing of political process distinctions points to a single overarching conclusion: Outright monetary subsidies are less likely than discriminatory tax breaks to take hold, to persevere, and thus to distort the geography of production in favor of local operators. ${ }^{150}$ That conclusion, moreover, suggests that there exists a sturdy basis for the traditional distinction between subsidies and tax expenditures in dormant Commerce Clause doctrine. This is so because, in cases such as Raymond Motor Transportation, Inc. v. Rice, ${ }^{151}$ the Supreme Court endorsed a reduced judicial activism when a "State's own political processes will act as a check on local regulations that unduly burden interstate commerce."152

The critic may well observe, however, that Raymond and kindred cases use the "political processes" principle in a way that is different from the way it is used here. When the Court applies this principle in the usual case, it asks whether there are state residents who can and will provide "surrogate representation" for nonresidents disadvantaged by the challenged state law. ${ }^{153}$ Here, however, no argument has been offered that the interests of favored residents and disfavored nonresidents are more closely aligned when a state grants a subsidy than when a state grants tax relief. (In fact, as we shall soon see, the alignment between in-state and out-of-state interests in both settings

on investment levels or location decisions, [tax incentives for economic development] continue to be widely endorsed by state legislatures. . . By contrast with tax-side subsidy programs, direct state aid to businesses appears to be relatively scarce."); $i d$. at 147 ("[S]tate and local economic development programs give us a rare glimpse of the impacts of differing mechanisms of accountability. Appropriated spending in these programs is relatively restrained .... Programs operating outside the appropriations process seem to be larger and to grow faster."); NORTHEAST MIDWEST INST., supra note 111, at 233 (noting that "[t]ax breaks are among the oldest and most prevalent type of economic development inducement"); SCHWEKE ET AL., supra note 24, at 17 ("Tax incentives, the traditional tool of industrial recruitment, are still the most commonly used development incentive."). See generally Hellerstein \& Coenen, supra note 27, at 816-34 (detailing numerous tax-based business development incentives). Though enacted much less frequently than tax breaks, direct cash subsidy programs do exist. See, e.g., MOSES, supra note 111, at 7 ("Some states give direct grants to industry, particularly for projects which, in the state govemment's view serve the public interest. Indiana's Rural Development Fund, for example, has issued grants covering up to 50 percent of a minor project's cost."); NORTHEAST MIDWEST INST., supra note 111, at 48-52 (describing various state business development incentive programs, including those of Arkansas, Connecticut, and Pennsylvania, cach of which includes some cash grant program).

150. For a judicial endorsement of this concept, see Pelican Chapter, Associated Builders \& Contractors, Inc. v. Edwards, 901 F. Supp. 1125, 1137 (M.D. La. 1995), in which the court reasoned that "tax exemptions are inherently different from subsidies . . . [in part] because of the inherent safeguards involved."

151. 434 U.S. 429 (1978).

152. Id. at 447.

153. See infra note 213 and accompanying text. 
is the same. ${ }^{154}$ Instead, the reasons that discriminatory subsidies are less likely to proliferate than discriminatory tax breaks concern the internal dynamics of state lawmaking processes. ${ }^{\text {is }}$ It may be, according to the critic, that local voters and their representatives will more readily focus on, question, and impede efforts to put in place outright subsidy awards. But that fact, the critic will say, simply does not trigger the surrogate-representation principle that the Court drew upon in Raymond and endorsed in other cases.

The proper response to this critique is: So what? If the underlying policy of the dormant Commerce Clause is to avoid distortion of the geography of production within our national market, and state subsidization poses less risk of distortion than do tax credits, exemptions, and deductions, that should be good enough. ${ }^{156}$ No further explanation for reliance on our long list of political process distinctions seems necessary, whether or not the traditional surrogate-representation principle is implicated. ${ }^{157}$ Nonetheless, if some further justification is required, it can be supplied. That additional justification derives from broadly ascendant themes in modern constitutional theory.

\section{Constitutional Theory}

The factors articulated above suggest that judicially unchecked political processes are less likely to produce monetary subsidy programs than

154. See infra notes 214-215 and accompanying text.

155. See supra notes 109-150 and accompanying text.

156. Put somewhat differently, the surrogate-representatuon pnnciple is merely (or at least essentually) a means to an end: namely, the end of maximizing the operation of an open. discnmunation-frec national common market. The critical point is that a variety of polscies may jeopandize or promole this end, whether or not surrogate representation is present. In particular, because discnminatory tax relief measures threaten the national market more than outright monetary subsidies (because of the operation of the seven political process considerations described above), it makes sense to distınguish between these two forms of state action in developing dormant Commerce Clause rules. Cf. Heinzerlıng, supra note 18. at 252 (suggestıng that surrogate-representation analysis reflects the value of "forcing those who enjoy benefits (by way of state action] to think hard about whether they're worth thetr cosis").

Yet another way of looking at the matter is that reliance on these seven factors to support the distinction between subsidies and tax breaks comports with the surrogate-representation pnnciple iself. This is so because ordinary in-state taxpayers are always potental surrogate representalives of out-of-state business interests who are threatened with disadvantage by esther subsidies or tax breaks asmed at local businesses. In essence, however, the functional considerations collected above suggest that local taxpayers are far more likely to be effective or real surrogates in the subsidy context than in the tax break one. If this is true, it seems sensible to say that the distinction between subsidies and tax breaks comports with the surrogate-representation principle itself. Cf. infra note 213 (notung that the opcration of the surrogalerepresentation principle depends on the nature $\longrightarrow$ and not just the presence-of the surrogate representation involved in the case).

157. Cf., e.g., United States v. Printz, 117 S. Ct. 2365. 2378 n.12 (1997) (favonng a pnnciple that rejects congressionally mandated state administration of federal programs in favor of conditional spending and other programs that encourage and induce state administration because "the condition of voluntary state participation significantly reduces the ability of Congress to use this device as a means of reducing the power of the Presidency"); City of Boeme v. Flores, 117 S. C1. 2157.2169 (1997) ("Strong measures appropriate to address one harm may be an unwarranted response to another. lesser one."). 
economically comparable discriminatory tax relief. This fact, as we have seen, is relevant under existing Commerce Clause case law, as exemplified by the principle of the Raymond case. Wholly apart from the Court's Commerce Clause jurisprudence, however, the political process considerations identified above have constitutional significance. Indeed, distinguishing between subsidies and tax breaks resonates with a trilogy of themes that run through much of modern constitutional thought: the themes of ensuring accountability, of facilitating deliberative decisionmaking, and of recognizing the collaborative, multibranch nature of much constitutional lawmaking.

\section{a. Accountability}

In recent years, the Court has emphasized in a variety of settings the importance of ensuring the accountability to the electorate of government decisionmakers. In New York v. United States, ${ }^{158}$ for example, Justice O'Connor rejected a claimed congressional authority to force states to adopt regulatory programs because, without a constitutional restriction on this form of congressional action, "the accountability of both state and federal officials is diminished." ${ }^{159}$ Likewise, in United States $v$. Lopez, ${ }^{160}$ the Justices who supplied the pivotal votes observed: "Were the Federal Government to take over the regulation of entire areas of traditional state concern, ... [t] the resultant inability to hold either branch of the government answerable to the citizens [would be] dangerous ...." ${ }^{161}$ This norm of accountability-which the Court has invoked in other contexts as well ${ }^{162}$-is advanced by the distinction between subsidies and tax breaks precisely because of the heightened visibility

158. 505 U.S. 144 (1992).

159. Id. at 168.

160. 514 U.S. 549 (1995).

161. Id. at 577 (Kennedy, J., concurring).

162. See, e.g., Loving v. United States, 116 S. Ct. 1737, 1743 (1996) ("The . . . clear assignment of power to a branch . . . allows the citizen to know who may be called to answer for making, or not making, those delicate and necessary decisions essential to governance."); 44 Liquormart, Inc. v. Rhode Island, II6 S. Ct. 1495, 1511 (1996) (questioning the Court's earlier validation of a prohibition on casino advertising because it "served to shield the State's antigambling policy from the public scrutiny that more direct, nonspeech regulation would draw" and noting its "longstanding hostility to commercial specch regulation of this type"); Central Hudson Gas \& Elec. Corp. v. Public Serv. Comm'n, 447 U.S. 557, 566 n.9 (1980) (expressing concern about the government's choice of regulatory means that "could screen from public vicw the underlying governmental policy"); id. at 575 (Blackmun, J., concurring in the judgment) (attacking, in the commercial speech context, government means that cause "the State's policy choices [to be] insulated from the visibility and scrutiny that direct regulation would entail"); see also Penell v. San Jose, 485 U.S. 1, 22-23 (1988) (Scalia, J., concurring in part and dissenting in part) (criticizing de facto subsidization of poor tenants by landlords through rent-control regulation because it can "be achieved 'off budget' with relative invisibility and thus relative immunity from the democratic process" and noting that "voters might well see other, more pressing social priorities" if funds for this purpose were to come directly from "the municipal treasury" because "both economic effects and competing priorities [would be] more evident"). 
and periodic reviewability of subsidy grants. ${ }^{163}$ In essence, if government is going to channel benefits selectively to favored groups, there is reason to say it must do so in the fashion that local residents most readily can see, understand, and question. ${ }^{164}$ Recognizing a dormant Commerce Clause distinction between subsidies and tax breaks comports with this constitutional goal.

\section{b. Deliberative Decisionmaking}

In addition, the distinction between subsidies and tax breaks corresponds with the growing emphasis in constitutional thought on the facilitation of "deliberative democracy." 165 From this point of reference-drawn from the writings of the Framers ${ }^{166}$-value lies in "widespread discussion among representatives and the citizenry at large" about important government decisions. ${ }^{167} \mathrm{~A}$ commitment to this value, like a commitment to government accountability, suggests there is good reason to steer state decisionmaking with respect to financial aid for local business into the field of affirmative subsidization. Why? Because, as we have seen, government decisions about subsidies are more likely to provoke public critique and to generate periodic reevaluation than economically comparable decisions about tax policy. ${ }^{163}$ Deliberative constitutionalism also puts a premium on justifying government programs with "public-regarding reasons"169 that transcend private "selfinterest" and "raw political power." ${ }^{\text {" }}$ Because of their lower visibility, tax breaks seem more susceptible to interest group abuses in this regard. For this reason, too, the notion of deliberative democracy supports the traditional distinction between discriminatory tax breaks and discriminatory subsidies.

163. See supra notes $112-125$ and accompanying text.

164. See SCHWEKE ET AL., supra note 24, at 49 ("[T] he best way forward would be to make incentuves more accountable to the general public interest .....").

165. CASS R. SUnStein, The PARTIAL CONSTITUTION 10 (1993); see also El.y. supra note 105. al 102-03 (noting that the judiciary must guarantee open access to the political process to prevent the process from serving only the interests of an elite few).

166. See, e.g., SUNSTEIN, supra note 165, at 9, 20-24.

167. Id. at 10; see also Cass R. Sunsiein. Interesi Groups in American Public Law. 38 STAN L. REV 29 (1985) (favoring a more active judicial role in policing legislatures to ensure genuinely deliberalıve, public-interest-based choices free from factional influences). For a general treatment of legislauve palterns. see Daniel A. Farber \& Philip P. Frickey, The Jurisprudence of Public Choice. 65 TEx. L. REV. 873, 874 (1987), which seeks to answer the "fundamental" question "whether legislatures can clam to formulate public policy legitimately."

158. Cf. Laurence H. Tribe, The Emerging Reconnechon of Indwidual Rights and Instutustonal Design. Federalism, Bureaucracy, and Due Process of Lawmakeng, 10 CREIGITON L. REV $+33 .+11-46$ (1977) (claiming that cour decisions should be deciemined in part by the manner in which legislation was passed).

169. SUNSTEIN, supra note 165 , at 19.

170. Id. at 25 . 


\section{c. Collaborative Lawmaking}

Finally, the distinction between subsidies and tax breaks squares with the Court's recent inclination to view the making of constitutional law as a cooperative venture in which the judicial branch is only one participant. ${ }^{171}$ The Court has moved toward this joint-undertaking conception of constitutional law in a variety of contexts. Even while signaling, for example, that no significant state regulatory immunity limits congressional powers, ${ }^{172}$ the Court has held that Congress may interfere with traditional state activities only when it legislates in clear terms. ${ }^{173}$ Similarly, Congress must make its wishes apparent when it seeks to supplant such core state choices as who is eligible to hold state office ${ }^{174}$ and whether the state is subject to a monetary judgment. ${ }^{175}$ In the dormant Commerce Clause sphere itself, the Court has reaffirmed traditional nexus rules ${ }^{176}$ but it has indicated that those rules are subject to revision by Congress, ${ }^{177}$ at least if it makes its choices "unmistakably clear." 178 Behind all of these rulings lies the notion that the

171. For scholarly discussion of this trend, see, for example, William Eskridge, Jr. \& Philip P. Frickey, Quasi-Constitutional Law: Clear Statement Rules as Constitutional Lawmaking, 45 VAND. L. REV. 593 (1992); and Calvin R. Massey, Etiquette Tips: Some Implications of "Process Federalism," 18 HARV. J.L. \& PUB. POL'Y 175 (1994). Cf. TRIBE, supra note 4, § 4-14, at 273 (suggesting that the presidential damages immunity rule of Nixon v. Fitzgerald, 457 U.S. 731 (1982), is congressionally reversible).

172. See Garcia v. San Antonio Metro. Transit Auth., 469 U.S. 528 (1985).

173. See BFP v. Resolution Trust Corp., 511 U.S. 531, 544 (1994) ("Federal statutes impinging upon important state interests 'cannot . . . be construed without regard to the implications of our dual system of government ...."' (quoting Felix Frankfurter, Some Reflections on the Reading of Statutes, 47 CoLUM. L. REV. 527, 540 (1947))); see also TRIBE, supra note 4, § 5-8, at 316 ("The Supreme Court has invoked the clear statement requirement most notably where a judgment that a federal statute reached to the outer limits of the commerce power would be obviously inconsistent with state institutional interests."); id. §625 , at 480 ("By declining to infer preemption in the face of congressional ambiguity, the Court ... [is] furthering the spirit of Garcia by requiring that decisions restricting state sovereignty be made in a deliberate manner by Congress...."); Andrzej Rapaczynski, From Sovereignty to Process: The Jurisprudence of Federalism After Garcia, 1985 SUP. CT. REV. 341 (discussing Garcia's effect on the balance of power between the federal and state systems).

174. See Gregory v. Ashcroft, 501 U.S. 452, 461 (1991) ("This plain statement rule is nothing more than an acknowledgement that the States retain substantial sovereign powers under our constitutional scheme, powers with which Congress does not readily interfere.").

175. See Employees of Dep't of Pub. Health \& Welfare v. Department of Pub. Health \& Welfare, 411 U.S. 279, 285 (1973) (articulating a "clear language" requirement for congressional negation of Eleventh Amendment immunity).

176. See Quill Corp. v. North Dakota, 504 U.S. 298, 309-18 (1992). The nexus test is the first part of the four-pronged analysis described in Complete Auto Transit, Inc. v. Brady, 430 U.S. 274 (1977), used to determine whether a state tax can withstand a Commerce Clause challenge. See Quill Corp., 504 U.S. at 311. The Court had earlier held, and confirmed in Quill Corp., that "a vendor whose only contacts with the taxing state are by mail or common carrier lacks the 'substantial nexus' required by the Commerce Clause [to uphold the tax]." Id. The Court emphasized that this "substantial nexus" test is not the equivalent of the "minimum contacts" test that must be met before a person can be forced to defend a suit in state court. Id. at 311-13.

177. See Quill Corp., 504 U.S. at 318-19.

178. E.g., Maine v. Taylor, 477 U.S. 131, 138 (1986) (citing South-Cent. Timber Dev., Inc. v. Wunnicke, 467 U.S. 82, 91 (1984)). More specifically, the Court in Quill Corp. carried forward the tax 
judicial and popular branches are involved in a collaborative implementation of constitutional values. ${ }^{179}$ Thus, Congress may override important constitutional norms that the Court has recognized and protected, but to do so it must-at the Court's insistence-make a clear and conscious choice to that effect to ensure that competing interests have been fully and fairly weighed. ${ }^{180}$

Much the same logic supports the Commerce Clause distinction between state tax breaks and state subsidies. Invalidation of a state tax break does not strip state legislators of all authority to advantage a local producer. To take such action, however, those legislators must resort to the more straightforward, politically visible, and periodically reviewable mechanism of outright subsidization. The constitutional principle at work in this area thus operates much like process-centered "second look" doctrines used to police state action in a variety of settings. ${ }^{181}$ In effect, through the use of such doctrines, the judiciary may "remand" constitutionally suspect political decisions back to state legislatures for consideration of whether to reinstate the earlier decision in a more cautious, studied, and procedurally untainted manner. ${ }^{182}$ One way of viewing many dormant Commerce Clause rulings is that they have this effect. ${ }^{183}$ Against this backdrop, it seems sensible to say-just as the cases

nexus rule of National Bellas Hess, Inc. v. Deparment of Reverure, 386 U.S. 753 (1967) In so doing. however, the Court held that the rule flowed only from the dormant Commeree Clause (uhich produces results that are congressionally reversible) and not from the Fourteenth Amendment Due Process Clause (which produces results that only constitutional amendments can alter). The Court, moreover. left no doubt about what it saw as a principal advantage of this approach:

[I]n recent years Congress has considered legislation that would 'ovemule' the Bellas Hess rule. Its decision . . may, of course, have been dictated by respect for our holding in Bellas Hess that the Due Process Clause prohibits States from imposing such taxes, but today we have put that problem to rest. Accordingly, Congress is now free to decide whether, when, and to what extent the States may burden interstate mail-order concerns with a duty to collect use taxes.

Quill Corp., 504 U.S. at 318.

179. See, e.g., Massey, supra note 171. at 177 (reportung "the emergence of a hybnd form of federalism, neither completely political nor wholly legal" and staung that "the emerging "process federalism' is one characterized by a willingness to let Congress impose its will upon the states so long as that imposition is performed in a procedurally restraned fashon").

180. See TRIBE, supra note 4 , § 5-8, at 316.

181. Second look "jurispradence requires that when the legislature has acted with haste or hiding in a way that arguably infringes even upon the penumbra of fundamental nghts. courts should invalidate the possibly offending law and force the legislature to take a "second look" with the eyes of the people on tt " Calabresi, supra note 122, at 104. Thus, for the challenged legislation to survive. "new politicians in a new set of circumstances, and with a new set of people looking at them. must reaffim the possibly offending law." Id. at 105; see also ELY, supra note 105, at 169: Alexander $M$. Bickel \& Harn $H$. Wellingion. Legislative Purpose and the Judicial Process: The Lincoln Mills Case. 71 HARv L REv 1. 16-35 (1957)

182. See, e.g., City of Richmond v. J.A. Croson Co., 488 U.S. 469 (1989) (pluralıty opinion) (striking down a set-aside for minority contractors in substantial part because of a lack of sufficient legislatıve findings to justify race-conscious remediation): see also Calabresi, supra note 122, at 145 ("“[S]ccond-look doctrines are designed to make legislatures and executives accountable. to make them responsive to the people.").

183. Two illustrative cases are Southern Pacific Co. v: Armzona, 325 U.S. 761 (1945). and Kussel y Consolidated Freightways Corp., 450 U.S. 662 (1981) (plurality opınion) In the Suuthern Pactfic case, the 
that propound the distinction between subsidies and tax breaks effectively do-that lawmakers inclined to benefit local industry must employ the legislative mechanism that minimizes risks of shortsightedness, onedimensionalism, and abuse.

\section{A Recapitulation}

Notwithstanding West Lynn Creamery, the traditional distinction between monetary subsidies and discriminatory tax breaks can lay claim to roots that sink deeply into Commerce Clause case law. This fact is not surprising given that-as we now have seen-four separate justifications support the traditional subsidy-protective rule. First, considerations of constitutional history provide a firm "formal" basis for distinguishing cash grants from discriminatory taxation. ${ }^{184}$ Second, a broad state power to subsidize rests on the fairnessbased notion that state residents should be able to reap where they have sown. ${ }^{185}$ Third, the traditional distinction vindicates values of federalism, by granting heightened authority to state governments to direct to the benefit of the state's citizenry those tangible assets that the state itself owns. ${ }^{186}$ Finally, for many reasons-focusing on visibility, intelligibility, self-limitation, and impermanence-subsidies pose less of a threat to dormant Commerce Clause values than do discriminatory tax breaks. ${ }^{187}$ In sum, the long-recognized distinction between subsidies and tax breaks reflects far more than "magic words and labels." 188 It reflects instead, as many cases suggest it should, "economic realities" 189 and "“practical effect." 190

Court confronted a train length law that was more than 30 years old and stricter than the length laws in place in all other states. Relying on the district court's finding that the law had no reasonable relation to safety in light of then-current train technology, the Court struck down the law because of its significantly adverse effects on interstate commerce. Given the Court's reliance on the "unchallenged findings" of the lower court, Southern Pacific, 325 U.S. at 773, there is every reason to believe that the Court would have upheld the law upon reenactment if the reenactment had been accompanied by a serious legislative investigation that resulted in findings that the length limit created genuine safety advantages despite technological improvements. Likewise, in Kassel, the Court struck down a truck-length law, emphasizing the existence of troublesome exemptions created by the state legislature and the failure of the state "to present any persuasive evidence that 65-foot doubles are less safe than 55-foot singles." Kassel, 450 U.S. at 671 (plurality opinion); see also id. at $671 \mathrm{n} .12,676-77$. Again, there is every reason to believe that the Court would have upheld a reenacted truck-length law that lacked resident-favoring exemptions and was supported by defensible legislative findings on the safety benefits of the 55-foot restriction.

184. See supra Subsection II.B.1.

185. See supra notes $106-108$ and accompanying text.

186. See supra notes $106-108$ and accompanying text.

187. See supra notes $112-150$ and accompanying text.

188. Quill Corp. v. North Dakota, 504 U.S. 298, 310 (1992).

189. Complete Auto Transit, Inc. v. Brady, 430 U.S. 274, 279 (1977).

190. Oklahoma Tax Comm'n v. Jefferson Lines, Inc., 514 U.S. 175, 183 (1995) (quoting Complete Auto Transit, 430 U.S. at 279); see also NLRB v. Jones \& Laughlin Steel Corp., 301 U.S. 1, $41-42$ (1937) (stating that "interstate commerce . . . is a practical conception" and that "interferences with that commerce must be appraised by a judgment that does not ignore actual experience"). 


\section{THE WEST LYNN CREAMERY APPROACHES TO DistingUiSHING PERMISSIBLE AND IMPERMISSIBLE SUBSIDIES}

The preceding discussion teaches that the traditional distinction between tax breaks and subsidies "makes good sense and sound law."'91 Reaching that conclusion, however, gives rise to another large and complex question: How does one distinguish the ordinary subsidy that comports with the Commerce Clause from the exceptional subsidy that does not? ${ }^{192}$ The proper starting point for approaching this issue lies in West Lynn Creamery itself, for each of the three opinions in that case seeks to cast light on this problem. Unfortunately, as the ensuing discussion shows, none of these efforts meets with much success.

\section{A. Justice Stevens's Approach}

Writing for the majority, Justice Stevens found the Massachusetts program unconstitutional because it operated as the "'equivalent to a rampart of customs duties." 193 Because the effect of the tax on Massachusetts milk was "entirely (indeed more than) offset by the subsidy" to in-state milk producers, the program threatened to shift business from out-of-state to in-state dairy farmers. ${ }^{194}$ As Justice Stevens concluded: "This effect renders the program unconstitutional, because it, like a tariff, neutralizes advantages belonging to the place of origin."195

Justice Scalia quickly spotted the central problem with this analysis. Taken to its logical end, the majority's approach would invalidate almost all business subsidies because every subsidy in purpose and effect "neutralizes advantages" of unsubsidized interstate competitors. ${ }^{196}$ In other words, the majority's neutralized advantages reasoning, without more, would undermine the Cour's longstanding endorsement of ordinary subsidies.

The majority, however, did offer more: Justice Stevens devoted five full paragraphs to distinguishing West Lynn Creamery from the typical subsidy case. ${ }^{197}$ This effort, as we have seen, focused on Massachusetts's linkage of its milk subsidy and its milk tax. ${ }^{198}$ But why did this feature of the

191. Reeves, Inc. v. Stake, 447 U.S. 429,436 (1980).

192. Cf. Maltz, supra note 106. at $69-70$ ("Defining the procise scope of the subsidy exception is a complex task.").

193. West Lynn Creamery, Inc. v. Healy, 512 U.S. 186, 194 (1994) (quoung Baldwin v G A.F Seelig. Inc., 294 U.S. 511,527 (1935)).

194. Id. at 194-95.

195. Id. at 196 (citation omitted).

196. See id. at 208 (Scalia, J., concurring).

197. See id. at 199-203 (majority opinion).

198. See supra notes $48-50$ and accompanying text. 
Massachusetts program make a difference? According to Justice Stevens, the "conjoining"199 of the tax and the subsidy triggered two special concerns. First, it had a problematic impact on state "political processes" because the subsidy "mollified" in-state dairy farmers who otherwise would have opposed the tax. ${ }^{200}$ Second, the "entire program" not only benefited in-state milk (as would an ordinary subsidy), but also burdened out-of-state milk (as an ordinary subsidy would not). ${ }^{201}$ Justice Stevens's focus on these facts suggests that, in his view, they should guide future efforts to distinguish permissible and impermissible subsidy programs. The difficulty with this position is that neither explanation for the result in West Lynn Creamery (at least without substantial refinement) holds much persuasive force.

\section{The Surrogate-Representation Distinction}

Assessments of political dynamics have long played a role in judicial application of the dormant Commerce Clause. In West Lynn Creamery, Justice Stevens drew upon this analytical tradition in framing his first distinction between ordinary subsidies and the Massachusetts program. As he explained:

[W] hen a nondiscriminatory tax is coupled with a subsidy to one of the groups hurt by the tax, a state's political processes can no longer be relied upon to prevent legislative abuse, because one of the in-state interests which would otherwise lobby against the tax has been mollified by the subsidy. So, in this case, one would ordinarily have expected at least three groups to lobby against the order premium, which, as a tax, raises the price (and hence lowers demand) for milk: dairy farmers, milk dealers, and consumers. But because the tax was coupled with a subsidy, one of the most powerful of these groups, Massachusetts dairy farmers, instead of exerting their influence against the tax, were in fact its primary supporters. ${ }^{202}$

In dissent, Chief Justice Rehnquist came down hard on this line of reasoning by claiming that "[a]nalysis of interest group participation in the political process may serve many useful purposes, but serving as a basis for interpreting the dormant Commerce Clause is not one of them." ${ }^{203}$ This criticism seems misguided, however, because for decades the Court has consulted interest group participation in the political process when applying the

199. West Lynn Creamery, 512 U.S. at 199.

200. Id. at 200.

201. Id. at 201.

202. Id. at 200-01.

203. Id. at 215 (Rehnquist, C.J., dissenting). 
dormant Commerce Clause..$^{204}$ Thus, nearly sixty years ago, the Court upheld South Carolina regulations that limited truck weight in part because "they affect alike shippers in interstate and intrastate commerce in large number." 205 This fact mattered, the Court explained, because the predictable opposition to the law by "some interests within the state" ensured that there were "political restraints" on its ill-advised enactment. ${ }^{206}$ In a long list of later cases, the Court has continued to consider the impact of "interest group participation" in assessing legislation under the dormant Commerce Clause. ${ }^{207}$ Given this consistent practice, the Chief Justice's critique of Justice Stevens's "political processes" distinction has a hollow ring. ${ }^{203}$

To say that the Chief Justice missed the boat in his critique, however, is not to say that Justice Stevens's political process analysis provided a steady anchor for the result in West Lynn Creamery. Indeed, that analysis is subject to a powerful criticism not mentioned by the dissenters at all. According to Justice Stevens, a political process problem infected the Massachusetts tax because one group "ordinarily... expected" to oppose the tax (namely, Massachusetts dairy farmers) would and did favor the tax because of the

204. See, e.g., Heinzerling, supra note 18. at 251-52 (The polutucal process leading to the enactment of laws that discriminate against outside commerce is an important theme of the Court's decistons

205. South Carolina State Highway Dep't v. Barnwell Bros., 303 U.S. 177. 187 (1938)

206. Id. at 184-85 n.2.

207. See, e.g., C \& A Carbone, Inc. v. Town of Clarkstown, 511 U.S. 383, 404 (1994) (O' Connor. J., concurring) (noting that the Court has "consistently recognized" that the presence of interests within the regulating jurisdiction that are as equally affected as interests outside of the junsdiction "counsels against a finding of discrimination"); Goldberg v. Sweet, 488 U.S. 252. 266 (1989) (noung that "the insider who is able to complain about and change the tax through the [state] political process" deserves less judicial protection than burdened outsiders "who would have difficulty effectung legislatuve change"); Kassel v Consol. Freightways Corp., 450 U.S. 662, 675-76 (1981) (pluralıty opımion) (refusing to give deference to a legislative determination of safety needs where "the local regulation bears disproportionately on out-ofstate residents and businesses"); Minnesota v. Clover Leaf Creamery Co., 49 U.S. 456,473 n. 17 (1981) (noting that "[t]he existence of major in-state interests adversely affected by the Act is a powerful safeguard against legislative abuse"); Nippert v. City of Richmond, 327 U.S. 416.434 (19.46) (stnhing down a "drummer" tax in part because "[p]rovincial interests and local polıtucal power are at their maximum ueight in bringing about acceptance of this type of legislation"): McGoldnck v Benwind-White Caal Mlining Co . 309 U.S. 33, 45-46 n.2 (1940) (noting that "to the extent that the burden falls on exonomic interests without the state, it is not likely to be alleviated by those poltical restraints which are nomally exented on legislation where it affects adversely interests withın the state"). See generally. TRIBE, supra note 4. \$ 6-5. at 408-13 (citing numerous authorities); Collins. supra nole 27, at 67 (notıng that "many opınıons since Barnwell have mentioned local political restraint as a factor in dormant commerce power analysis").

208. Indeed, Chief Justice Rehnquist himself has invoked this analytical tradition in argung that the operation of in-state "political processes" counseled the consulutionality of a state law that "work[ed] to the substantial disadvantage of . . . segments of the State's populatson." Fort Gratiot Santary Landfill, Inc. v. Michigan Dep't of Natural Resources, 504 U.S. 353. 370 (1992) (Rehnquist. CJ.. dissentıng). Simularly. Justice Blackmun-who joined the Chief Justuce's West Lynn Creamen dissenung opinion-freely consulted interest group dynamics in other cases that called for application of the domant Commerce Clause principle. See, e.g., Commonwealth Edison Co. v. Montans, 453 U.S. 609. 649 (1981) (Blarkmun. J., dissenting); see also Dan T. Coenen, Justice Blackmun. Federalism and Separahon of Powers. 97 Dick L. Rev. 541, 560 n.115 (1993). Indeed, just a month before joining the Chief Justice's opinion in IVest Lynn Creamery, Justice Blackmun joined Justice Souter in invoking Bamiell's "polsucal restrannts" analysis. See Carbone, 511 U.S. at 426 (Souter, J., dissentung). 
accompanying subsidy. ${ }^{209}$ That is true, but irrelevant in isolation. States often pass tax laws that grant more favorable treatment to some taxpayers than others, be they low-wage earners, parents of young children, or companies that invest in pollution abatement equipment. That one group of citizens may be "mollified" 210 when a tax law is enacted does not, in itself, render the law suspect under the dormant Commerce Clause. 211

The proper inquiry in Commerce Clause cases thus is not whether some in-state group has been protected from the impact of the challenged statute. Instead, the proper inquiry is whether the impact of the challenged law falls on "other States' economic interests," without significantly disadvantaging "local economic interests" as well. ${ }^{212}$ It is, after all, economic activity in and with other states that the dormant Commerce Clause seeks to safeguard. "Thus, the presence of an in-state surrogate who may assert the claims of burdened out-of-state interests serves to lower the level of commerce clause scrutiny."213

Justice Stevens was right to conclude that the Massachusetts milk program was constitutionally suspect under this form of analysis. Why? Because the law disadvantaged out-of-state dairy farmers without disadvantaging politically potent in-state dairy farmers at all. There is, however, a basic difficulty with Justice Stevens's analysis: It does not, as it was supposed to do, logically

209. West Lynn Creamery, 512 U.S. at 200.

210. Id.

211. Put somewhat differently, legislative mollification of one or more groups in enacting legislation cannot alone be a litmus of constitutionality "because all legislation is by its nature redistributive." Steven G. Calabresi, Some Normative Arguments for the Unitary Executive, 48 ARK. L. REv. 23, 81 (1994); see also Collins, supra note 27, at 69 ("[E]very law adversely affects some market actors in the statc.").

212. Kassel, 450 U.S. at 675 (plurality opinion); accord, e.g., Clover Leaf Creamery Co., 449 U.S. at 473 \& n.17 (noting, in finding a state milk container law constitutional, that most challengers of the law were in-state firms).

213. TRIBE, supra note $4, \S 6-5$, at $411-12$. Moreover, in making this assessment, courts will consider the nature of the disadvantaged in-staters because some groups are far more effective political surrogates than others. See, e.g., POSNER, supra note 105, at 525 ("[C]onsumers fare badly in the legislative process: They are too numerous to organize an effective 'cartel' in support of or in opposition to existing or proposed legislation."); Collins, supra note 27, at 69 ("Political allocation of goods chronically disadvantages small consumers."); $i d$. ("When internal costs are large, and those bearing them are practically able to influence the political process ... there is less justification for judicial intervention."); Frank H. Easterbrook, The State of Madison's Vision of the State: A Public Choice Perspective, 107 HaRv. L. REV. 1328, 1342 (1994) ("From Madison's time to ours, students of politics have recognized that producers are concentrated relative to consumers and so more readily can overcome the frec riding problem that obstructs collective action."); Barbara J. Redman, The Market Regulator-Market Participant Distinction and Supreme Court Vigilance over Discriminatory State Programs: Does Economic Theory Justify the Judicial Effort?, 25 AM. BuS. L.J. 585, 598 (1988) (noting that governments do not always serve "to maximize the welfare of the citizens of the state as a whole" because policymakers tend to respond disproportionately to "strongly felt preferences," including those of certain minorities, like "a coalition of producers within a major industry"); Regan, supra note 4, at 1141 (noting that "consumers as a group are less likely to be organized politically than farmers, manufacturers, or workers"). 
distinguish West Lynn Creamery from the ordinary subsidy case. ${ }^{214}$ If lawmakers had proposed a simple in-state dairy farmer subsidy program, after all, the benefited farmers would have supported that program as surely as they supported the program actually put in place. Indeed, in terms of representation reinforcement analysis, the actual Massachusetts program was less problematic than a straightforward subsidy program because the tax imposed by the actual Massachusetts program was payable by in-state milk dealers. It is improbable that dealers would have opposed a simple subsidy paid to Massachusetts farmers; in fact, dealers might well have supported such a subsidy as a probable catalyst of lower producer prices. Because the actual Massachusetts program laid a tax on dealers, however, it threatened their own pocketbooks in such a way that they could be expected to serve as "surrogates" for out-ofstate dairy farmers in opposing the law. ${ }^{215}$

In short, Justice Stevens's attempt to use representation reinforcement analysis to place the Massachusetts milk program in the impermissible tax break category-rather than the permissible subsidy category-lacks persuasive force. ${ }^{216}$ On this score, there simply was no basis for a heightened suspicion that "Massachusetts ... created a program more dangerous to interstate commerce" than a subsidy program standing alone. ${ }^{217}$

\section{The Burden-and-Benefit Rationale}

Justice Stevens took a second crack at distinguishing Massachusetts's milk producer payments from the ordinary subsidy when he observed:

214. As Professor Drahozal comments.

The majority in West Lynn Creamery argued that "because the tax was coupled ${ }^{\prime}$ ith a subsidy. one of the most powerful of these groups [that would otherwise lobby agannst the tax]. Massachusetts dairy farmers, instead of exering their influence against the tax, were in fact its primary supporters." . . The majonty's analysis has the taul wagging the cow. The pncing order was not structured as it was to buy off opponents of a general milk tax. It was structured as it was to transfer wealth to milk producers with the least politucal opposition by others Drahozal, supra note 33 , at $1163 \mathrm{n} .185$ (ctition omitted) (alteration in origunal).

215. Indeed, the plaintiff who challenged the Massachusetts program in Hest Linn Creamen was a substantial in-state milk dealer. See West Lynn Creamen. 512 U.S at 186. For an explanilton of the effects of the Massachusetts plan on in-state milk dealers, see Heınzerling. supra note 18. at 246 Heinzerling notes:

All milk dealers-whether they purchased ran milh from in-slate or out-of-stale producers-were required to make the same payment to the state In effect, for Massachusetts milk dealers, the Massachusetts pricing order merely ratsed the pnce they were required to pay in order to transact in a given quantity of milk. Id.

216. Cf. Heinzerling, supra note 18, at 246-47 (noung that the West Lym Creamen Court's "sole focus was on the pricing order's potential impact on out-of-state producers. whose injury, if any. would result from the subsidy to in-state producers" (footnote omuted))

217. West Lynn Creamery, 512 U.S. at 200. 
A pure subsidy funded out of general revenue ordinarily imposes no burden on interstate commerce, but merely assists local business. The pricing order in this case, however, is funded principally from taxes on the sale of milk produced in other States. By so funding the subsidy, [the State] not only assists local farmers, but burdens interstate commerce. ${ }^{218}$

This mode of differentiating the Massachusetts subsidy program and the ordinary subsidy is suspect on its face, for courts and commentators have often noted the dubious character of claimed distinctions between beneficial and burdensome laws. ${ }^{219}$ Moreover, reliance on this distinction seems especially

218. Id. at 199 (footnote omitted).

219. See, e.g., Lucas v. South Carolina Coastal Council, 505 U.S. 1003, 1024 (1992) ("[T]he distinction between 'harm-preventing' and 'benefit-conferring' regulation is often in the eye of the beholder."); Metropolitan Life Ins. Co. v. Ward, 470 U.S. 869, 882 (1985) (declaring that whether a state law is "benefiting one group or . . . harming another" is a "distinction without a difference"); Heinzerling. supra note 18, at 262 (noting that the distinction between burdens and benefits has been "elsewherc ridiculed by the Court" and "merely states rather than explains the Court's conclusion"). Lower courts have noted the evanescence of this distinction in applying the dormant Commerce Clause. See Alliance for Clean Coal v. Miller, 44 F.3d 591, 596 (7th Cir. 1995) (striking down an Illinois law that required a utility's installation of scrubbers that permitted burning of high-sulphur Illinois coal, and rejecting the state's argument that the law "merely 'encourages' the local coal industry and does not in fact discriminate"); $i d$. ("By 'encouraging' the use of Illinois coal, the Act discriminates against western coal by making it a less viable compliance option." (citation omitted)); Fireside Nissan, Inc. v. Fanning, 30 F.3d 206, 216 (Ist Cir. 1994) (finding a "blurring" in "the imaginary line between discriminatory privileges that burden interstate commerce and those that do not"); see also Smith Setzer \& Sons v. South Carolina Procurement Revicw Panel, 20 F.3d 1311, 1321 (4th Cir. 1994) ("[A]ll, or almost all, state action results in some persons being benefitted while others are burdened ....); J. Filiberto Sanitation, Inc. v. New Jersey Dep't of Envtl. Protection, 857 F.2d 913, 919 (3d Cir. 1988) ("The essential question is whether the challenged regulation confers an advantage upon in-state economic interests-either directly or through imposition of a burden upon out-of-state interests-vis-a-vis out-of-state competitors." (citation omitted)).

Moreover, contrary to what seems to be the premise of Justice Stevens, much rhetoric in the Supreme Court cases suggests that state laws that discriminatorily "benefit" local businesses are as problematic as those that "burden" out-of-staters. For example, the Court has said that states "may not "impose a tax which discriminates against interstate commerce ... by providing a direct commercial advantage to local business." Oklahoma Tax Comm'n v. Jefferson Lines, Inc., 514 U.S. 175, 197 (1995) (quoting Northwestern States Portland Cement Co. v. Minnesota, 358 U.S. 450, 458 (1959) (emphasis added)); see also C \& A Carbone, Inc. v. Town of Clarkstown, 511 U.S. 383, 389 (1994) ("It is well settled that actions are within the domain of the Commerce Clause if they burden interstate commerce or impede its free flow.") (emphasis added); id. at 393 ("The Commerce Clause presumes a national market free from local legislation that discriminates in favor of local interests." (emphasis added)); id. at 417 (Souter, J., dissenting) (noting that "laws "adopted for the purpose of improving the competitive position of local economic actors, just because they are local, vis-a-vis their foreign competitors' . . . offend the Commerce Clause" (citation omitted) (emphasis added)); id. (expressing concern about state laws that have "advanced the economic interests of its own business classes at the expense of its neighbors" (emphasis added)); Oregon Waste Sys., Inc. v. Department of Envtl. Quality, 511 U.S. 93, 106 (1994) ("[R]egulating interstate commerce in such a way as to give those who handle domestic articles of commerce a cost advantage over their competitors handling similar items produced elsewhere constitutes [prohibited] protectionism." (emphasis added)); Freeman v. Hewit, 329 U.S. 249, 252 (1946) ("A state is . . precluded from taking any action which may fairly be deemed to have the effect of impeding the free flow of trade between States." (emphasis added)). For an illustrative discussion of the problems inherent in the benefit-burden distinction, see SUNSTEIN, supra note 165 , at 209-13, which criticizes the distinction between benefits and penalties in the First Amendment context. See also Cass R. Sunstein, Lochner's Legacy, 87 CoLUM. L. REV. 873, 876 (1987) ("The notion of subsidy is of course incoherent without a baseline from which to 
strained in the dormant Commerce Clause context because of the Court's recurring insistence that attention should focus on the challenged statute's "practical effect."220 Assume, for example, that the Massachusetts tax-andsubsidy program had two principal effects. First, it put the average nonresident producer "out" $\$ 1.00$ per hundredweight of milk sold (based on taxes paid by the dealer, but "passed back" to the producer through an insisted-upon equivalent price reduction). Second, it put the average in-state producer "in" $\$ .50$ for each hundredweight sold (based on an average of $\$ 1.50$ per hundredweight in subsidies minus the passed-back $\$ 1.00$ per hundredweight in dealer-paid taxes). The combined operation of these effects would give the instate producer an unearned advantage of $\$ 1.50$ per hundredweight as it fixed its prices in competition with out-of-state producers. ${ }^{231}$

Assume next that, instead of adopting a tax-and-subsidy program, the state had simply given in-state producers a subsidy of $\$ 2.50$ per hundredweight, with the consequence that in-state producers received an unearned advantage of $\$ 2.50$ per hundredweight over out-of-state competitors. One need not consult Albert Einstein to see that the pure subsidy grant would have more "distorting effects on the geography of production"222 than the actual Massachusetts program. Put differently, if the $\$ 1.50$ per unit price advantage creates a danger of distortion, a $\$ 2.50$ price advantage "exacerbates the danger by giving domestic producers an additional tool" (in the form of one additional dollar per hundredweight of milk sold) "with which to shore up their competitive position."223

If that is the case, however, how can it be that the actual program-but not the hypothesized program-violates the Commerce Clause? Justice Stevens's answer seems to be that, while the hypothesized program "benefits" local producers, it does not "burden" out-of-state producers. This assertion, once again, ignores real world practicalities. Out-of-state sellers, after all, surely will view themselves as burdened when they are unable to sell their product in a state because subsidized competitors are able to slash prices. ${ }^{22}$ In any event,

make a measurement.").

220. Complete Auto Transit, Inc. v. Brady. 430 U.S. 274, 279 (1977).

221. This is not to suggest, of course, that this was the actual effect of the Massachusetts program. Indeed, the existence of federal price controls may have limited the dealer's abtlity to "pass back" the full tax amount. There is little reason to doubt, however, that any "pass-backs" that did oceur were directed in equal amounts to in-state and out-of-state producers. That is the critical point for purposes of this illustration.

222. West Lynn Creamery, 512 U.S. at 193.

223. Id. at 197 (emphasis added); see also Enrich, supra note 18, at 446 ("Indeed. once a differentıal impact on in-state and out-of-state activities has been established, it is unclear what work the distuncuon between benefits and burdens is to do.").

224. See Drahozal, supra note 33, at 1159 ("Subsidies in large states do not merely assist local business; they benefit it by burdening out-of-state compettors."): Gergen. supro note 22. at 1135 ("When a subsidy encourages local firms to increase production or new firms to enter a trade. the subsidy injures 
while there is rhetoric in the case law suggesting that a state must be "burdening out-of-state competitors" for Commerce Clause protections to attach, ${ }^{225}$ there also is language that points the other way. ${ }^{226}$ Perhaps most significantly, in Bacchus Imports, Ltd. v. Dias, ${ }^{227}$ the Court seemed to reject just such verbal legerdemain. As the Court stated:

Virtually every discriminatory statute allocates benefits or burdens unequally; each can be viewed as conferring a benefit on one party and a detriment on the other, in either an absolute or relative sense. The determination of constitutionality does not depend on whether one focuses on the benefited or burdened party. ${ }^{228}$

In sum, Justice Stevens's dual reasons for distinguishing the Massachusetts program from the ordinary subsidy stand on shaky ground. Accordingly, they will be of limited usefulness as courts in the future seek to draw a principled line between constitutional and unconstitutional subsidy programs.

\section{B. Justice Scalia's Approach}

For the reasons just mentioned, Justice Scalia was right to find fault with the majority opinion in West Lynn Creamery. ${ }^{229}$ His own attempt to distinguish the Massachusetts program from the ordinary subsidy, however, turns out to be no more satisfying than the majority's effort.

In a salutary effort to bring focus to the case, Justice Scalia began his analysis by explaining:

foreign producers through both a decline in the price of affected goods and a loss of market share. Indecd, the effects of subsidies are generally the same as those of tariffs."); Heinzerling, supra note 18, at 262 (arguing that subsidies impose a "burden" because they "may drive outside competitors out of business"); Kline, supra note 22, at 354, 378 (asserting that the market participant doctrine "condones state-sponsored discrimination 'burdening' the interstate market" because "foreign business concems must meet the augmented efficiencies of local firms"); Note, supra note 31, at 1542 (stating that "subsidies . . benefit the local producer while burdening interstate commerce"); The Supreme Court, 1975 Term-Leading Cases, supra note 39, at 61 (arguing that subsidies burden out-of-state competitors). As Professor Drahozal observes: "[T] he Court's treatment of subsidies looks a lot like a return to the discredited distinction between direct and indirect burdens on interstate commerce." Drahozal, supra note 33, at 1142.

225. New Energy Co. v. Limbach, 486 U.S. 269, 273-74 (1988); see Enrich, supra note 18, at 444 ("The Court has frequently articulated its antidiscrimination principle in terms of the improper burdens placed on out-of-state businesses, products, or activities.").

226. See supra note 219 ; cf., e.g., Henneford v. Silas Mason Co., 300 U.S. 577, 586 (1937) (rejecting the use of "[c]atch words and labels" in applying the dormant Commerce Clause); Gregg Dycing Co. v. Query, 286 U.S. 472, 481 (1932) ("Discrimination, like interstate commerce itself, is a practical conception. We must deal in this matter, as in others, with substantial distinctions.").

227. 468 U.S. 263 (1984).

228. Id. at 273 .

229. Notably, however, the criticisms outlined in the preceding section are not the criticisms that Justice Scalia advanced. Moreover, Justice Scalia's criticisms are themselves-as we already have seen-subject to serious criticism. See supra notes 55-63 and accompanying text. 
There are at least four possible devices that would enable a State to produce the economic effect that Massachusetts has produced here: (1) a discriminatory tax upon the industry, imposing a higher liability on out-of-state members than on their in-state competitors; (2) a tax upon the industry that is nondiscriminatory in its assessment, but that has an "exemption" or "credit" for in-state members; (3) a nondiscriminatory tax upon the industry, the revenues from which are placed into a segregated fund, which fund is disbursed as "rebates" or "subsidies" to in-state members of the industry (the situation at issue in this case); and (4) with or without nondiscriminatory taxation of the industry, a subsidy for the in-state members of the industry, funded from the State's general revenues. ${ }^{230}$

According to Justice Scalia, while the taxes in categories one and two would be unconstitutional, the subsidy in category four would survive Commerce Clause attack. ${ }^{231}$ As for the question presented in West Lynn Creamery itself (i.e., the legality of the category three device), Justice Scalia explained:

The issue before us in the present case is whether the third of these methodologies must fall. Although the question is close, I conclude it would not be a principled point at which to disembark from the negative-Commerce-Clause train. The only difference between methodology (2) (discriminatory 'exemption' from nondiscriminatory tax) and methodology (3) (discriminatory refund of nondiscriminatory tax) is that the money is taken and returned rather than simply left with the favored in-state taxpayer in the first place. The difference between (3) and (4), on the other hand, is the difference between assisting in-state industry through discriminatory taxation, and assisting in-state industry by other means . . . .

I draw the line where I do because it is a clear, rational line at the limits of our extant negative-Commerce-Clause jurisprudence. ${ }^{232}$

The difficulty with this reasoning is that it begs most critical questions. In essence, Justice Scalia declared that methodology three involves "discriminatory taxation." discriminatory at all. ${ }^{234}$ Justice Scalia implied that the Massachusetts program could fairly be viewed as involving a tax "rebate" or "refund." 33 But so can

230. West Lynn Creamen;, 512 U.S. at 210 (Scalıa, J., concurnng)

231. See id. at 210-11.

232. Id. at $211-12$.

233. Id. at 211 .

234. See Heinzerling, supra note 18, at 270 ("[T]he premuun umposed on Massachusetts mulk dealers appears to be the legislative abuse the Court was seeking to prevent. But this premium did not discnminate against anyone.").

235. West Lynn Creameny, 512 U.S. at 210. 211 (Scalıa, J.. concumng) 
any monetary subsidy paid back to firms that are subjected to state iaxation (as most subsidized firms certainly are), particularly when the subsidy is specifically coupled with targeted "taxation of the industry."236 Justice Scalia correctly noted that the line between methodologies two and three is thin. ${ }^{237}$ But the line between methodologies three and four seems no less shadowy. Indeed, on Justice Scalia's reasoning, Massachusetts could have collected exactly the same taxes, calculated in exactly the same manner, from exactly the same milk dealers, and then paid out exactly the same amount of monies, to exactly the same producers, if only it had placed the collected taxes in "the general revenues" rather than "a segregated fund."238

On what "clear, rational" theory would the payments in these circumstances have ceased to be "refunds" or "rebates"? After all, in the usual case, tax refunds and rebates are paid from the general treasury. On what "clear, rational" theory could it be said that the actual case, but not the hypothetical case, involved "discriminatory taxation"? After all, in each case, the tax imposed would have been exactly the same. And on what "clear, rational" theory could Justice Scalia conclude that the general fund case, but not the segregated fund case, was "far removed from what we have hitherto held to be unconstitutional"? ${ }^{239}$ After all, for the reasons just given, the general fund case is plainly not "far removed"-if removed at all-from the case involving the segregated fund. Justice Scalia left these questions unanswered.

There is an additional and more basic difficulty with Justice Scalia's analysis: It hinges on his underlying, but unexplained, acceptance of the foundational distinction between state tax breaks and state subsidies. ${ }^{240}$ Apart from citing the "limits of our extant negative-Commerce-Clause jurisprudence," 241 however, Justice Scalia offered no reason in West Lynn

236. Id. at 210; see Drahozal, supra note 33, at 1161-63 (noting the problem presented by "a subsidy funded by a tax on the good being subsidized"); Patterson, supra note 18, at 1025 ("States receive the majority of their revenue from sales taxes. ... It is impractical and probably impossible for a state tax system to not impact out-of-state producers. If the general funds subsidize in-state producers, it is likely that out-of-state interests would provide some of the funds.").

237. See West Lynn Creamery, 512 U.S. at 211 (Scalia, J., concurring).

238. Id. at 210, 211. A student note also rejects Justice Scalia's segregated fund distinction: A firm is indifferent as to whether its subsidy comes from a segregated fund or from the general treasury. A dollar is worth a dollar regardless of its source: in either case, its effect is to lower a firm's marginal cost, and hence the price at which the firm can sell its goods without suffering a marginal loss.

Note, supra note 31, at 1541-42. Conceivably. Justice Scalia would reject the effort to distinguish the hypothesized case from West Lynn Creamery by characterizing it as involving a de facto "segregated fund." But such a position would only reveal more clearly the thinness of the claimed distinction between Justice Scalia's categories three and four.

239. West Lynn Creamery, 512 U.S. at 239 (Scalia, J., concurring).

240. See id. at 211-12 (Scalia, J., concurring).

241. Id. at 212 . 
Creamery for deeming this distinction "clear," "rational," or otherwise sound. To be sure, Justice Scalia hinted at two possible justifications for distinguishing tax breaks from subsidies in his earlier opinion in the New Energy case. ${ }^{242}$ But, again, a close look at these putative justifications shows that they lack sufficient explanatory power to guide courts called on in the future to decide whether particular subsidy programs are unconstitutional.

First, in distinguishing the Ohio ethanol tax credit struck down in New Energy from an ethanol subsidy adopted in Indiana, Justice Scalia had noted that the "assessment and computation of taxes" constitutes "a primeval governmental activity."243 One wonders, however, in what way this observation advanced informed analysis. To begin with, even if state taxation is a "primeval governmental activity," state spending is as well..$^{2+4}$ In addition, even assuming that state taxation is distinctively "primeval," it is doubtful that this fact should subject discriminatory tax breaks, but not discriminatory subsidies, to dormant Commerce Clause attack. If "primevalness" cuts in any direction, it would seem to favor the broadest legislative discretion in exercising state taxing powers. ${ }^{245}$ Finally, it is doubtful that "primevalness" could supply a useful litmus for distinguishing the constitutional from the unconstitutional state subsidy. To take the most immediate example, if primevalness provides the analytic key, why should the Court have invalidated the newfangled linked-tax-and-subsidy program at issue in West Lynn Creamery itself?

Justice Scalia's second attempt to distinguish impermissible tax breaks from permissible subsidies was based on the text of the Commerce Clause. As he explained the distinction:

242. New Energy Co. v. Limbach, 486 U.S. 269, $277-78$ (1988)

243. Id. at 277; see also Bair, supra note 22. at 2415 (noting that the Coun in New Energy distinguished earlier resource distribution decisions on the ground that "taxalton is a "pnmeval govermmental activity"'); Enrich, supra note 18, at 442 ("in partucular, although it may be plausible to characterize governmental cash subsidies as a form of participation in the market for the subsidized goods. services, or activities that is akin to what private entuties do in bidding up the pnces for desired purchases. taxation is, as the Court has emphasized, 'a primeval governmental activity. "').

244. See San Antonio Indep. Sch. Dist. v. Rodriguez, 411 U.S. 1. 40 (1973) ("[T] he way in which [a state] has chosen to raise and disburse state and local tax revenues ... . (is] an area in which [the Court] has traditionally deferred to state legislatures." (emphasis added)).

245. The Court has shown solicitude in a variety of contexts to clams of state autonomy in areas "historically" or "traditionally" subject to state control. See United States v. Lopez. 514 U.S. 549. 563 (1995) (invalidating congressional regulation of firearms in school zones): Gregory v. Asheroft. S01 U.S. 452,460 (1991) (narrowly interpreting a congressional override of state-establıshed electoral qualificalions) The Court has also recognized, time and again. that "[s]tates have broad diseretion to configure thetr systems of taxation as they deem appropriate." Oregon Waste Sys.. Inc. v. Depastment of Envtl. Quality. 511 U.S. 93, 106-07 (1994); accord, e.g., Exxon Corp. v. Eagerton. 462 U.S. 176. 196 (1983) ("'Legislatures have especially broad latitude in creating classifications and distunctions in tax statules." (quoting Regan v. Taxation with Representation, 461 U.S. 540, 547 (1983))); Austun v New Hampshure. 420 U.S. 656, 661 (1975) (“' [I]n taxation, even more than in other fields, legislatures possess the greatest freedom in classification." (quoting Madden v. Kentucky. 309 U.S. 83.88 (1940))) 
The Commerce Clause does not prohibit all state action designed to give its residents an advantage in the marketplace, but only action of that description in connection with the State's regulation of interstate commerce. Direct subsidization of domestic industry does not ordinarily run afoul of that prohibition; discriminatory taxation of outof-state manufacturers does. ${ }^{246}$

Again, one wonders why. It is not self-evident that the award of subsidies to in-state producers fails to qualify as a "regulation" of interstate commerce. ${ }^{247}$ Many economists and lawyers would say just the opposite ${ }^{248}$ because the very purpose of subsidization is to regulate the flow of business by promoting in-state production. ${ }^{249}$ Indeed, at one juncture in New Energy itself, Justice Scalia observed that ordinary "subsidy programs ... might ... be characterized" as "regulatory activity."250

In sum, Justice Scalia's writings offer little or no real explanation for why tax breaks differ from subsidies for dormant Commerce Clause purposes; why "primevalness" or "regulatoriness" has justificatory power in this context; or why the segregated fund principle he advanced in West Lynn Creamery sensibly reflects "primevalness," "regulatoriness," or any other underlying constitutional concern. In addition, while Justice Scalia's approach might bring a greater level of determinacy to this area of law, it carries with it the twin

246. New Energy, 486 U.S. at 278; see also Mark V. Tushnet, Scalia and the Dormant Commerce Clause: A Foolish Formalism?, 12 CARDozo L. REv. 1717, 1727 (1991) ('The courts' authority to invalidate state legislation is . . . limited to consideration of state laws that regulate interstate commerce, not those that discriminate against out-of-state commercial activity in some other way, for example, by a direct cash subsidy.").

247. See, e.g., Gerald GunTHER, Constitutional Law 176 (12th ed. 1991) (noting that "the way in which revenues are spent [has] significant regulatory impacts" and that governmental "spending powers have been invoked to regulate . . . economic problems"); Regan, supra note 4, at 1112 ("Regulation' [may be] used in a broad sense [so that it] includes taxing and spending programs.").

248. See, e.g., Polelle, supra note 39, at 684 (asserting that "competition is nullified" and "protectionism is at work" as a result of subsidies, no less than with other forms of regulation).

249. Cf. Fireside Nissan, Inc. v. Fanning, 30 F.3d 206, 216 (1st Cir. 1994) (noting that a "diversionary effect is present in all subsidy cases"); Enrich, supra note 18, at 459 ("[A]lthough the market participant doctrine may provide a basis for distinction, cash subsidies to relocating businesses surely distort cconomic decisions in precisely the same way as tax benefits.").

250. New Energy, 486 U.S. at 269; see also New York v. United States, 505 U.S. 144, 175 (1992) (holding that a "congressionally compelled subsidy from state governments" amounts to federal action that "would 'commandeer' state govemments into the service of federal regulatory purposes" (cmphasis added)): Reeves, Inc. v. Stake, 447 U.S. 429, 440 n.14 (1980) (noting that some subsidy programs might be characterized as regulatory activity for purposes of the market participant exception to the dormant Commerce Clause). Of course, the Court has said that tax laws are "plainly connected to the regulation of interstate commence." Oregon Waste Sys., 511 U.S. at 107 n.9; accord Walling v. Michigan, 116 U.S. 446, 455 (1886) (stating that a "discriminatory tax ... operating to the disadvantage of products of other states... is, in effect, a regulation"). In this regard, are subsidies really any different? See, e.g.. Heinzerling, supra note 18, at 260 n.210 ("The language of the Commerce Clause does not answer this question. To be sure, the Clause applies only to the 'regulation' of interstate commerce, but it docs not define this term."); Polelle, supra note 39, at 658 (equating a state's behavior when it "uses subsidies" to its behavior "when it uses its normal regulatory powers to manipulate an existing market"). 
risks of drawing an essentially arbitrary line ${ }^{251}$ and of threatening to render West Lynn Creamery an all but empty gesture. ${ }^{252}$

In the end, Justice Scalia's West Lynn Creamery concurrence rests upon two distinctively personal viewpoints. First, it reflects Justice Scalia's strong, but probably quixotic, drive to discover and draw "clear" constitutional lines. ${ }^{253}$ Second, and more important, it derives from Justice Scalia's distinctive view that, because the Commerce Clause contains no "negative" component at all, he should honor only the strict letter of the Court's past decisions in this field. ${ }^{254}$ Lower courts, however, do not have the same

251. See infra Subsection V.B.2 (critiquing in detall the proposed segregated fund distunction).

252. See Note, supra note 31, at 1554 (altacking the segregated fund pnnciple on the ground that. under it, "[a]n otherwise unconstitutional tax becomes constitutional if the tax revenue simply makes a monetary pit stop in the general treasury"); see also Winkfield F. Twyman, Jr. Beyond Purpose: Addressing State Discrimination in Interstate Commerce, 46 S.C. L. REV. 381 , 425 (1995) ("Artiul draftung of neutral regulations should not be rewarded with more protection from the Court if these regulations result in discrimination that proves disruptive in effect."): Varat. supra note 22, at 542 (concluding. Without mention of fund segregation, that "the same impermissible result would be produced if resident and nonresident businesses were equally taxed but only resident businesses received cash subsidy rebalcs").

253. See Maryland v. Craig, 497 U.S. 836, 860 (1990) (Scalia, J.. dissenting); Sisson v Ruby. 497 U.S. 358, 371 n.2 (1990) (Scalia J., concurring); Bumham v. Supenor Coun. 195 U.S 604. 621 (1990) (plurality opinion) (Scalia, J.); Morrison v. Olson. 487 U.S. 654. $711-12$ (1988) (Scalta. J. dissentung): Antonin B. Scalia, The Rule of Law as a Law of Rules, 56 U. CHI. L. REv. 1175.1178 (1989) (arguing for clear rules because "the discretion-conferring approach ... does not satusfy (the) sense of justuce very well"). On Justice Scalia's effort to formulate a "clear" rule in Hest Lynn Creamen, sec Palterson, supra note 18, at 1005, which states that "[i]n an effor to shape the Couri's expansive reasoning. Jusice Scalia advocated a bright line between constitutionally permissible and impermissible subsidies " On Justice Scalia's gravitation to purportedly "clear" rules in general. see Nicholas S. Zeppos, Justice Scalus's Textualism: The "New" New Legal Process. 12 CARDOZO L. Rev. 1597. 1619 (1991). which observes that Justice Scalia's insistence on following clear statutory stnctures derives from "concem about judical activism" and represents one "of his repeated calls for clear, bnghi-line rules to cabin judicial discretion" Cf. Walter Hellerstein, Justice Scalia and the Commerce Clause: Reflections of a State Tux Lawver. 12 CARDOZO L. REV. 1763, 1787 (1991) (noting that Justice Scalia has "taken formalistic and restnctive positions" on state tax issues such as apportionment and discrimination)

Of course, volumes could be written on the advantages and disadvantages-and the discoverability and nondiscoverability - of clear constitutional rules. Even with respect to Jusuce Scalsa's own segregated fund test, for example, a number of questions come quickly to mind: What if the proceeds of muluple taxes are "segregated"? Is de facto segregation a possibility" Whal if subsidy funds come from a segregated fund generated by taxes imposed on another industry? A related industry? What if subsidies come from a segregated fund paid out to both in-state members of a taxed industry and to others (e.g., local dary farmers and local charities)? What if most of the segregated fund's proceeds are pasd to others? In short. even in applying Justice Scalia's test it remains true that "[I]he boundiry at which the conflicung interesis balance cannot be determined by any general formula in advance. but points in the line. or helping to establish it, are fixed by decisions that this or that concrele case falls on the nearer or farther side "Hudson Water Co. v. McCarter, 209 U.S. 349, 355 (1908) (Holmes, J.); see also Tushnet. supru note 246. at 173439 (discussing the practical difficulties of applyıng "formal" as well as "balancıng" rules)

254. See, e.g., Itel Containers Int') Corp. v Huddleston. 507 U.S. 60. 78.79 (1993) (Scalı. J.. concurring) (refusing to go further than invalidating "a state law that factally discrimunates agaunst interstate commerce" or "that is indistinguishable from a type of law previously held unconstututional by this Cour") Justice Thomas has joined Justice Scalia's aniculation of this case-on-point style of domant Commeree Clause jurisprudence. See West Lynn Creamery. Inc. V Healy. S12 U.S. 186, 210 (199-4) (Scalıa, J. concurring, joined by Thomas. J.). The view is nonetheless "distuncuve" in the critucal sense that no other Justice has expounded it, or anything like it, at least since Chief Justice Tancy left the Cour. See Trise. supra note $4, \S 6-3$, at 405 (noting Taney's rejection of the dormant Commerce Clause principle) 
options as a free-minded Supreme Court Justice. They must accept the settled proposition that there is a dormant Commerce Clause, abide by the logic and spirit of the Court's past Commerce Clause decisions, and seek principles that have a reasoned basis in light of those decisions for distinguishing permissible and impermissible state subsidies.

\section{Chief Justice Rehnquist's Dissent}

Parting ways with Justices Stevens and Scalia, Chief Justice Rehnquist defended the constitutionality of the Massachusetts program. Declaring the Court's earlier tax break cases inapposite, the Chief Justice found it "'not only a distinction, but a significant difference"" that the payment "in this case goes not to the entity which pays the tax (milk dealers) but to the dairy farmers themselves."255 The Chief Justice thus suggested that the critical criterion in assessing the constitutionality of state subsidy programs should be whether they direct payments on a discriminatory basis to the same persons whose tax payments create the subsidy fund. ${ }^{256}$ The difficulty with the Chief Justice's opinion is that it offered no reason why courts should draw this particular distinction between permissible and impermissible subsidy programs. This omission was especially surprising because the Chief Justice's approach (strange as it may seem) arguably fits best with the overarching principle that drove both the majority and concurring opinions in the West Lynn Creamery case. Both the majority and concurring Justices, after all, found a dormant Commerce Clause violation in West Lynn Creamery only after characterizing the subsidy payment as a tax "rebate" or "refund." 257 In ordinary parlance, however, a rebate or refund involves a return of money to the same person who paid it out. ${ }^{258}$ Moreover, the state's separation of its tax and grant targets had economic consequences that provided a basis for deeming the "rebate" or "refund" labels inapplicable to the Massachusetts milk payments. When a dealer buys milk, that dealer will take account of all transactionrelated costs as it chooses among competing suppliers. Thus, if the dealer's tax costs for in-state milk are negated due to a tax exemption or rebate afforded to the dealer itself, the dealer unquestionably will buy from in-state suppliers, all other things being equal. Given the structure of the Massachusetts scheme, however, the dealer did not receive this sort of purchasing incentive; instead,

255. West Lynn Creamery, 512 U.S. at 216 (Rehnquist, C.J., dissenting) (quoting id. at 197 n.14 (majority opinion)).

256. See id. at 216.

257. See supra notes 48,235 and accompanying text.

258. See Ballentine's Law Dictionary 1266 (6th ed. 1990) (defining "rebate" as "an amount handed back to the payer"). 
from the dealer's perspective, transaction-related tax costs for in-state and outof-state milk were identical. To be sure, the subsidy afforded to in-state producers would make in-state milk more attractive to the dealer if the in-state producer chose to pass all or part of that subsidy through to the dealer by way of price reductions. ${ }^{259}$ But there is only a possibility that the subsidy would be passed through and thus only a possibility that in-state milk would be more attractive to dealers. Thus, the subsidy would not-like a true tax exemption or rebate-necessarily make in-state milk more attractive to dealers with the direct consequence that less out-of-state milk would move in interstate commerce. Moreover, the economic argument for the Chief Justice's position draws strength from a body of precedent the Chief Justice neglected to mention-namely a series of Commerce Clause cases in which the Court has refused to assume that pass-throughs occur. ${ }^{260}$

Justice Stevens was unmoved by the Chief Justice's dissent. In his view:

Rebating the taxes directly to producers rather than to the dealers ... merely reinforces the conclusion that the pricing order will favor local producers. If the taxes were refunded only to the dealers, there might be no impact on interstate commerce, because the dealers might not use the funds to increase the price or quantity of milk purchased from Massachusetts dairy farmers. The refund to the dealers might, therefore, result in no advantage to in-state producers. On the other hand, by refunding monies directly to the dairy farmers, the pricing order ensures that Massachusetts producers will benefit. ${ }^{261}$

This reasoning is faulty because how milk dealers "use" any payments they receive is beside the point. What is critical is that conditioning the availability of rebates on a dealer's purchase and resale of in-state milk inexorably will induce the dealer to shift its purchases away from out-of-state suppliers. For this reason, it is simply erroneous to say that "Ii]f taxes were refunded only to the dealers, there might be no impact on interstate commerce." ${ }^{.62}$ On the

259. See infra text accompanying notes 267-268.

260. See McKesson Corp. v. Division of Alcoholic Beverages \& Tobacco, 496 U S 18, $46-47$ (1990) ("We repeatedly have recognized that determining whether a particular business cost has in fact been passed on to customers or suppliers entails a highly sophistıcaled theoretucal and factual inquiry land cannot be based] on sheer speculation that a "pass-on" occurred."); of Fulton Corp. v. Fulhner. 116 S Ci 848. 859 (1996) (citing "the frequently extreme complexity of economic incidence analysis"). Okiahoma Tax Comm'n v. Jefferson Lines, Inc., 514 U.S. 175. $196 \mathrm{n.7}$ (1995) (noting that "[t]he significance of the taxpayer's identity is . . . central to" domant Commerce Clause tax cases). Bu of Evansville-Vanderburgh Airpor Auth. Dist. v. Delta Airlines, Inc., 405 U.S. 707. 714 (1972) (“"W]e do not thunk i panteularly important whether the charge is imposed on the passenger himself, to be collecled by the arrline, or on the airline, to be passed on to the passenger if it chooses.").

261. West Lynn Creameny. 512 U.S. at 197 n.l4

262. Id. 
other hand, if Massachusetts dairy farmers did not pass back the subsidy payments paid out to them (because, for example, each of them immediately made a gift of all such payments to the Vesuvian Cosmetology College), then dealer purchasing patterns would not change at all, and there would in fact be "no impact on interstate commerce" in milk. It is true that if "rebates" were to go to dealers, a dealer might, no less than a producer, use the extra cash to philanthropize purveyors of cosmetology skills. But the dealer would nonetheless certainly switch its purchasing to in-state milk-and thereby alter interstate movement of this product-so as to maximize the resources it could use to make its salutary donations.

Responding in another way to the argument that "dealers who pay ... the tax ... are not competitors of the farmers who receive disbursements,"263 Justice Stevens observed that "[f]or over 150 years, our cases have rightly concluded that the imposition of a differential burden on any part of the stream of commerce... is invalid."264 This observation is question-begging, however, because the central issue in West Lynn Creamery was whether the Massachusetts program should be characterized as imposing a "differential burden" in the first place. To be sure, "a higher sales tax on milk produced in Maine than milk produced in Massachusetts ... would be struck down."265 But that assertion does not answer the question whether a neutral tax on dealers should be characterized as discriminatory because of a supposed "rebate" given, not to dealers, but to local milk producers who only might pass through to dealers the benefit of that subsidy.

Despite these problems, there is much to be said for the majority's rejection of the Chief Justice's wooden refusal to apply the rebate label to a subsidy paid to a dairy farmer, rather than the taxed wholesaler of that dairy farmer's product. To begin with, whatever else the Massachusetts milk subsidy was, it was uniquely tax-related-and thus particularly susceptible to characterization as a tax rebate-because it was funded solely with the proceeds of the simultaneously enacted milk-dealer tax. In addition, to the extent any pass-back of the tax to producers occurred at all, the program operated almost exactly like the patently unlawful protective tariff. ${ }^{266}$ Finally,

263. Id. at 198 .

264. Id. at 202 .

265. Id.

266. See supra notes $92-96$ and accompanying text. This is the case because, if a tax burden were thus imposed indirectly on milk producers through lower milk prices, only in-state producers would reccive a rebate payment of the "tax" thus paid. In fact, the respondent in West Lynn Creamery claimed that no such taxes were "passed back" through producer price reductions. See Respondent's Brief at 17, West Lymn Creamery (No. 93-141). It seems likely, however, that some pass-backs occurred. See Collins, supra note 27, at 70 (noting that government charges can be "pass[ed]-on" either to "suppliers or customers"): Regan, supra note 4, at $1120 \mathrm{n} .59$ (noting "that in the final analysis the burden is almost certainly shared by all parties, including producers"). Even if there seemed to be no pass-backs, however, it would be wrong not 
if any subsidy benefits were passed forward by in-state dairy farmers to local dealers in the form of voluntary producer price reductions (and there is every reason-given the purpose of the program-to conclude that this form of passthrough occurred ${ }^{267}$ ), the program very closely tracked the tax exemption scheme invalidated without difficulty in Bacchus Imports, Lid. v. Dias. ${ }^{263}$ In both cases, after all, a wholesaler received a government-generated benefit solely because it chose to deal with the local supplier of a government-favored product.

In the end, Justice Rehnquist's "it's-not-a-rebate" argument failed because it was perceived to hinge on the sort of "nice distinction" the Court's Commerce Clause cases eschew. ${ }^{269}$ Perhaps the best way to view the Massachusetts program is that it set up the most tariff-like tax-and-subsidy structure possible without obviously violating the Commerce Clause. In particular, Massachusetts could not have imposed its tax directly on producers because an attempt to tax directly out-of-state producer sales would have violated (at least in most cases) the nexus prong of the Court's Complete Aluto Transit test. ${ }^{270}$ Similarly, Massachusetts could not have directed its subsidy to taxpaying dealers on the basis of their Massachuselts milk sales because, after Bacchus Imports, that would have constituted patently discriminatory relief afforded to taxpayers themselves. ${ }^{271}$ It might be said that, by dodging these pitfalls, Massachusetts escaped all constitutional difficulties. It is certainly as sensible to say, however, that Massachusetts resorted to impermissible "subterfuge"272 to circumvent the strictures of the Commerce Clause. "The Constitution "nullifies sophisticated as well as simple-minded

to apply the anti-tariff rule logically applicable to this class of cases merely because this extraordinary circumstance appeared to pertain in this particular case. This conclusion is reinfored by an inability to say with any confidence that pass-backs did not occur. As Patterson notes.

The incidence of a tax on a dealer may be partially or fully shifted backwards to the producen or forward to the consumers. In fact, whether a tax was collecled from milk consumers or frum milk dealers, the impact of the tax theoretically would not change. With the exception of controlled economic experiments, however, it is very difficult to measure the effects of taxes as they pass through the economy.

Patterson, supra note 18, at 1010-11; see also Suellen M. Wolfe. Mfunctpal Finance and the Commerce Clause: Are User Fees the Next Target of the "Silver Bullet". 26 STETSON L REV 727. 799 (1997)

("Requiring a specific and detailed economic analysis of a tux burden is not possible or justufied ")

267. See West Lynn Creamen: 512 U.S. at 196 n. 10.

268. 468 U.S. 263 (1984). For a discussion of Bacchus Imports, see infra notes $365-369$ and accompanying text.

269. Baldwin v. G.A.F. Seelig. 294 U.S. 5II. 522 (1935): see also POS\ER, supru note 105, at 642 (rejecting the relevance of whom the tax is "on" and "where the nominal subject of the tax is physically located").

270. See Complete Auto Transit, Inc. v. Brady. 430 U.S. 274. 277.79 (1977). ud at 279 (requinng a "substantial nexus with the taxing state"); see also, e.g., Quill Corp v. North Dahola. S04 L'S 298. 311-19 (1992) (applying the nexus principle to strike down a state tax law as applied to sellers who lacked a physical presence in the state).

271. See infra notes 365-370 and accompanying text.

272. Henneford v. Silas Mason Co., 300 U.S. 577. 587 (1937) 
modes' of infringing on Constitutional protections." 273 For this reason, the majority had good cause to reject the claim that channeling in-state milk payments to local producers, rather than to local dealers, ipso facto removed any constitutional infirmity from the Massachusetts milk program.

\section{TOWARD A FunCtional FRAMEWORK FOR TAX-Linkage ANALYSIS}

In both New Energy and West Lynn Creamery, members of the Court explicitly or implicitly advanced a variety of possible approaches for drawing the constitutional line between permissible and impermissible subsidy programs. Yet, as we saw in Part III, each of these approaches-whether based on surrogate representation, the benefit-burden dichotomy, "primevalness," "regulatoriness," use of a segregated fund, or differentiation of taxpayer and subsidy recipient-seems demonstrably misguided, or at least incomplete. ${ }^{274}$ The challenge thus remains to craft a more sensible set of organizing principles for distinguishing between constitutional and unconstitutional state subsidies. In Section IV.A, I consider a number of principles proposed by other legal commentators. Finding each of these approaches unsatisfactory, I advance my own proposed methodology in Section IV.B.

\section{A. Other Commentators' Approaches}

Several scholars have offered suggestions for marking the distinction between constitutional and unconstitutional state subsidies. These efforts, however, are sparse in detail and, in most cases, tentative and preliminary in nature. More important, each effort is open to serious criticism on doctrinal and policy grounds. I turn now to an examination of these proposals, which focus on maximization of efficiency, creation of commerce, and sheltering subsidies that accompany a general (rather than an industry-specific) tax.

\section{The Low-Cost-Subsidy and Efficient-Subsidy Principles}

Professor Regan has floated the idea that courts should target for invalidation monetary subsidies that "achieve a substantial redirection of

273. U.S. Term Limits, Inc. v. Thornton, 514 U.S. 779, 829 (1995) (quoting Lane v. Wilson, 307 U.S. 268,275 (1939)).

274. Cf. Drahozal, supra note 33, at 1131 ("State tariffs certainly are unconstitutional under the ... dormant Commerce Clause; state subsidies, funded from the general revenues of the state, appear to be entirely constitutional. The Supreme Court has given no persuasive justification for this differing treatment."). 
business to local producers at very little cost."275 To his credit, Professor Regan has tried to build this organizing principle on a policy said to distinguish subsidies from other forms of impermissible state discrimination-namely, the policy that subsidies pose a reduced risk to our national market because of their inherent costliness. ${ }^{276}$ As I have already noted, however, the "expensiveness" policy on which Professor Regan relies is of dubious legitimacy because tax expenditures, no less than cash expenditures, are inherently costly. ${ }^{27}$ In addition, as I have observed elsewhere: "[T]here will be great difficulties both in creating and in sorting out the type of 'carefully calibrated' subsidies Professor Regan identifies. Lack of necessity and problems of judicial manageability thus converge to favor restraint in invalidating [these] subsidy programs." 278 Perhaps the best evidence that this criticism has merit comes from Professor Regan himself. As he has written: " $[\mathrm{T}]$ he informational demands for designing the dangerously cost-effective subsidy are just too great." ${ }^{\text {"279 }}$

Taking a related approach, some observers have suggested that courts should sustain or strike down a subsidy depending on whether it contributes to "utility maximization." ${ }^{.280}$ The approach of these observers reminds us of a key background proposition: Many monetary subsidies serve useful purposes, so that barring them all (or even barring them as a general rule) risks serious harm. ${ }^{281}$ Yet, any test that calls on judges to sort between the efficient and inefficient subsidy on a case-by-case basis would-as Professor Gergen has argued-"strain their capacity and vest in them undue discretion to decide close questions of value." ${ }^{\text {282 }} \mathrm{A}$ major problem is that there is no readily available standard for deciding whether a particular subsidy is efficient, or even for deciding what efficiency means in this context. A subsidy might be deemed economically defensible, for example, if it pays a firm for the

275. Regan, supra note 4, at 1196 (deeming it "imporant that the benefits that are limited to locals be expensive for the state").

276. See id.

277. See supra notes $112-114$ and accompanying text.

278. Coenen, supra note 22, at 479.

279. Regan, supra note 4 , at 1196.

280. See, e.g., Bair, supra note 22, at 2423 ("[C]ourts should sinke down those contractual preferences that create large inefficiencies.....); see also Gergen, supra note 22, at 1107 (noung that "[s]everal scholars have explicitly taken an economic perspective on these issues").

281. See Regan, supra note 4, at 1194 ("Many spending programs are posilively beneficial from the point of view of the nation as a whole ... ."): Note. supra note 31. at 1547 (noting that "subsidics can be a socially beneficial means of encouraging an optimal level of production"); Palterson, supro note 18, at 982 ("A state may address market failures with subsidies that conform production to its true costs."): $u$. at 983 ("Traditionally, courts tolerate subsidies because subsidies often can produce beneficial social as well as economic consequences, and regulating them would be administratively difficult.").

282. Gergen, supra note 22, at 1110. 
generation of positive externalities. ${ }^{283}$ But what counts as a positive externality? If the amount of the subsidy must approximate the value of the positive externality, how are we to measure that value? Apart from valuing the positive externality, must that value be offset by the costs imposed by negative externalities generated by the firm? And when (if ever) should an in-state firm's generation of positive externalities entitle it to a subsidy not paid to competing out-of-state firms that generate positive externalities of their own (either in the state, outside the state, or both)? These sorts of judgments are not likely to be welcomed by a Court that recently declared itself "institutionally unsuited to gather the facts upon which economic predictions can be made, and professionally untrained to make them."284

Responding to such concerns, Professor Gergen has taken a different approach, drawing on both the value of efficiency maximization and "concerns that a rule be administrable"285 to propose categories of permissible and impermissible resource-distribution preferences. $^{286}$ Like a case-by-case approach, however, this methodology is distinctively wedded to neoclassical wealth maximization; it thus seems to clash with the Court's prior counsel that the "Constitution does not require the states to subscribe to any particularly economic theory." 287 In addition, as I have observed elsewhere, Professor Gergen's own carefully developed efficiency-related categories are open to question on efficiency grounds. ${ }^{288}$ In short, the problem remains that any efficiency-driven analysis (whether undertaken on a case-by-case basis or in a more categorical way) is likely to prove deeply problematic in application, particularly for busy judges who are not professional economists. ${ }^{289}$

283. See Note, supra note 31 , at $1548 \mathrm{n} .64$ (citing articles in the economics literature for the proposition that "the government should impose subsidies" when "there is a positive externality").

284. General Motors Corp. v. Tracy, 117 S. Ct. 811,829 (1997).

285. Gergen, supra note 22 , at 1107.

286. See id. at 1132-52.

287. CTS Corp. v. Dynamics Corp. of Am., 481 U.S. 69, 92 (1987); see also supra notes 133-134 and accompanying text.

288. See Coenen, supra note 22, at 416-17 (questioning, for example, the proposed distinction beliveen medical services and cement sales).

289. See, e.g., Clayton P. Gillette, a Skeptical View of Federal Constraints on State Business INCENTIVES 26 (University of Va. Working Paper Series No. 97-1, 1997) (questioning the competence of courts to distinguish socially beneficial and nonbeneficial business development incentives); Michael E. Smith, State Discrimination Against Interstate Commerce, 74 CAL. L. REv. 1203, 1211 (1986) ("[T]he courts might undertake to determine whether the overall economic benefits and burdens of a regulation favor local inhabitants against outsiders. Even expert economists might find themselves hard put to make this determination."); $c f$. Commonwealth Edison Co. v. Montana, 453 U.S. 609, 619 n.8 (1981) (noting "the formidable evidentiary difficulties" in resolving such issues as elasticity of demand for the product and altemative sources of supply (citing Developments in the Law: Federal Limirations on State Taxation of Interstate Business, 75 HARV. L. REV. 953, 970 (1962))).

Professor Gergen himself recognizes that "formulating a simple rule that can distinguish wealthcreating subsidies from those that are inefficient is virtually impossible." Gergen, supra note 22, at 1137. To this thought the following might be added: A central purpose of federalism is to facilitate experimentation, and experimentation necessarily envisions state forays into programs that might not be-or 


\section{The Commerce-Creation Principle}

Professor Tribe, ${ }^{290}$ with some support from an early opinion by Justice Stevens, ${ }^{291}$ has advocated a different principle. In Tribe's view, state programs are open to attack if they distort existing markets, but are unobjectionable if they create new market activity and then channel it into the state. ${ }^{292}$ I have suggested elsewhere that, contrary to Professor Tribe's claim, this principle lacks support in the Supreme Court's existing decisions. ${ }^{293}$ The Tribe approach also seems misdirected because it is difficult to conceive of any subsidy designed to stimulate additional economic activity within the state that has no adverse impact at all on interstate markets. If this is so, the real question raised by the Tribe test cannot be whether a particular state subsidy has no effect on interstate commerce; instead, the judicial inquiry must focus on whether that effect is de minimis or whether the essential thrust of the state program is to stimulate new commercial activity of potential benefit to the nation as a whole. These judgments, however, involve just the sort of evidentiary problems and inevitable speculations that the Court historically has eschewed. $^{294}$

at least might not seem at first blush to be-economically efficient To put the point differently. an important goal of federal experimentation is to provide a iesung ground for determining whether state programs that do not seem efficient really are efficient in the sense that the benetits they produce outucigh the costs they impose. There is a danger that any up-front efficiency-centered standard for evaluatung state subsidy programs will conflict with this basic purpose of federalism.

290. See TRIBE, supra note 106, at 144-46.

291. See Hughes v. Alexandna Scrap Corp., 426 U S. 794, 816 (1976) (Stevens, J , concumng)

292. See TRIBE, supra note 106. at 146. Professor Regan also seems sympathetuc to this view See Regan, supra note 4, at $1196 \mathrm{n.203}$ (endorsing constıtutional ummunity "on the ground that the bounty scheme did create the relevant commerce").

293. See Coenen, supra note 22, at 410-14. In particular, Professor Tribe has asserted that this commerce-creation principle explains the outcome in Alexandria Scrap In that case. the Coun upheld subsidies paid by Maryland for the destruction of inoperable cars with a discriminatory preference for instate processors. Professor Tribe has claimed that this discriminatory subsidy was permissible only because it created a new market in junk car processing. The record in the casc. houescr. suggested that a preexisting market existed and that cars otherwise destined to be crushed outside Maryland were divented to in-state processors due to the availability of subsidy funds See Aletandria Scrap. 426 U S at $+12-13$. see also Regan, supra note 4, at 1196 n.202 (noting that the Court in Alexandru Scrap did not rely on the claim that the state created the commerce its bounty scheme affecied).

294. See Fulion Corp. v. Faulkner. 116 S. Ct. 848. 855 n.3 (1996) (nejecung a '“de munumis" defense to a charge of discriminatory taxation under the Commerce Clause"), wd. at 859 (noung that courts ".are poorly equipped to evaluate with preciston the relatsve burdens of vanous methods of taxation'" and that “" $t$ ]he complexities of factual economic proof always present a certan potentual for error". (quotung Minneapolis Star \& Tribune Co. v. Minnesota Comm'r of Revenue. 460 U.S. 575. 589-90 (1983))); Bacchus Imports, Lid. v. Dias, 468 U.S. 263, 269 (1984) ("[N]etther the small volume of sales of exempted liquor nor the fact that the exempted liquors do not constltute a present 'competuive threat' to other liquors is dispositive ...."); see also Reeves, Inc. v. Stake. 447 (' S. 429. $\$ 45$ (1980) (rejectung an attempt to escape the market participant rule on the ground that the state's consiruction of a cement plant undermined the operation of a preexisting private market in cement because the argument's factual premise was unduly "speculative"); cf. Collins, supra note 27, at 102 ("It would . be difficult to separate subsidies that burden preexisting trade from those that stimulate new trade ") Indecd. even protective tanffis (as well as 
Professor Tribe's notion, however, may lay the groundwork for a more measured and manageable subsidy-sorting principle. On this view, a strong line marks the boundary between protectionist devices (designed, at least in part, to safeguard existing industry from competitive pressures) and development incentives (designed solely to expand economic activity within the subsidygranting state in an objectifiable way). ${ }^{295}$ In particular, the pro-development principle would shelter those subsidies (but only those subsidies) made specifically contingent on the generation of new and greater economic activity in the state-for example, the building of a new facility, the purchase of additional equipment, or the hiring of more workers. ${ }^{296}$ From this perspective, for example, it would be fine for South Carolina to pay cash to BMW to build a new manufacturing plant within the state's borders. But it would not be all right for South Carolina to share subsidy payments with preexisting in-state auto manufacturers or (presumably) to make payments to an existing in-state firm that is threatening to relocate to Minnesota. ${ }^{297}$

Embracing this sort of distinction, however, falls far short of removing all analytical difficulties. ${ }^{298}$ One problem is that so-called "business

innumerable discriminatory taxing schemes) could be defended on the ground that they promote the establishment and growth of local business activity without unduly hampering the activities of out-of-state firms. The Court, however, has never engaged in this sort of calculus when confronting programs of this kind. See supra notes $92-96$ and accompanying text.

295. This distinction is hinted at (with respect to both outright subsidies and tax credits) in Justice Stevens's concurrence in Alexandria Scrap. As Justice Stevens stated:

Nor, in my judgment, does that Clause inhibit a State's power to experiment with different methods of encouraging local industry. Whether the encouragement takes the form of a cash subsidy, a tax credit, or a special privilege intended to attract investment capital, it should not be characterized as a 'burden' on commerce.

426 U.S. at 816 (Stevens, J., concurring).

296. For two lines of possible defense for this type of incentive, see Drahozal, supra note 33, at 1129 n.9, which states that "[i]nstead of discriminating against out-of-state producers and protecting local businesses, relocation subsidies discriminate against in-state producers and, thus, generally have avoided constitutional challenge under the dormant Commerce Clause"; and Tatarowicz \& Mims-Velarde, supra note 35, at 933 n.261, which argues:

[T]he typical investment credit, jobs credit, or research credit may not have been enacted with the primary intent of diverting activity from other states. Instead, many tax incentives appear to have been enacted to encourage a higher level of the desired activity (investment or jobs or research) within the state through the creation of more of the activity. There may be no (or little) diversion of the activity from other states and hence no negative effects on interstate commerce.

Of course, to the extent that tax breaks of this nature are constitutional (as some have argued they should be, at least as applied to certain forms of taxes, see supra note 81), it should follow a fortiori that economically equivalent outright subsidies are unobjectionable. Cf. Regan, stipra note 4, at 1193 ("The state can waive property taxes on new manufacturing plants, thereby securing jobs for local workers at the expense of foreign.").

297. See generally Hellerstein \& Coenen, supra note 27 , at $849-53$ (considering the constitutionality of subsidies of this nature).

298. See id. at 849-55; see also Varat, supra note 22, at 545 (suggesting the propriety of similar treatment of "expenditure . . . to attract industry, employment, and commercial prosperity to, or to keep it in, the subsidizing state"). 
development" incentives often come with strings attached. If, for example, a subsidy is awarded to the owner of a newly built plant-but only on an annual basis for so long as the plant generates a specified output in the state-is the subsidy properly viewed as a business development incentive, a stay-at-home subsidy, or a "protectionist" measure that props up an already established instate business? In addition, the drawing of a line between expanding businesses and businesses unwilling or unable to grow rests uncomforably beside the Court's longstanding insistence that "no principle of Commerce Clause jurisprudence support[s] a distinction between thriving and struggling enterprises." 299

Most important, any rule that singularly safeguards new business development subsidies seems both over and underinclusive from the standpoint of traditional Commerce Clause policy. The rule is underinclusive because some desirable subsidies do not involve business expansion. ${ }^{300}$ The rule also seems overinclusive, however, if one is prepared to draw on the Commerce Clause to outlaw some business subsidies. This is the case because, in Commerce Clause tax and regulatory cases, the Cour often has condemned state actions that induce "business operations to be performed in the home state that would more efficiently be performed elsewhere." ${ }^{301}$

In the BMW hypothetical, for example, it is probable that South Carolina's actions would not contribute to expansion of the national economy; instead, because BMW was going to build its plant somewhere in the United States, South Carolina's action would merely induce BMW to locate its plant in a state where it otherwise might not have gone. ${ }^{302}$ It is for this reason that the use of business development incentives creates the risk of an ill-advised "race

299. Bacchus Imports, 468 U.S. at 272; see also West Lynn Creamery. Inc. Y Healy, 512 U S. I86. 205 (1994) ("Whether a State is attempting to 'enhance thrving and substantual business enterprises" or to "subsidize ... financially troubled" ones is irrelevant to Commerce Clause analysis" (quoung Bacchus Imports, 468 U.S. at 272)).

300. See supra note 281 and accompanying text. By way of example. It may sometimes be advisable to "bail out" a critical local business threatened by insolvency. This should be true. for example, where the cost of a subsidy needed to get a business back on its feet is less than the cost of its liquidation $C f$ Gergen, supra note 22, at 1141 (arguing that a "measure may be of net benefit to sociely if by a small expenditure the city can encourage local employment and accrue substantial savings in public suppor from those escaping the dole, provided that the disappointed outsiders can find work at only slightly less return elsewhere").

301. Pike v. Bruce Church, 397 U.S. 137, 145 (1970), quoted in Westinghouse Elec Corp. $\vee$ Tully. 466 U.S. 388, 406 (1984); accord, e.g.. Toomer v. Witsell, 334 U S 385. 403-04. 406 (1948); FosterFountain Packing Co. v. Haydel, 278 U.S. 1, 13 (1928); see also Camps Newfound/Owatonna. Inc $\vee$ Town of Harrison, 117 S. Ct. 1590, 1604 (1997) (reiteratıng that under well-established Court junsprudence "discriminatory tax exemptions" used "as a means of encouraging the growth of local trade" are "impermissible").

302. Cf. Gergen, supra note 22, at 1135 ("IA] subsidy may not stumulate increased production if, for example, a state causes an industry to relocate to a place where its marginal costs are higher, but where that increase is offset by aid from the state."). 
to the bottom" among the states, ${ }^{303}$ a race that seems at odds with the Commerce Clause vision of a "federal free trade unit" location occurs in response to market forces rather than state manipulations. ${ }^{305}$ In light of these concerns-as well as the advisability of avoiding a rule that might generate a pointless cycle of never-ending business relocations-there is no good reason to single out "business development" subsidies for special and preferred treatment. ${ }^{306}$

\section{The Industry-Specific-Tax Distinction}

Another approach-trumpeted by a student note in the Harvard Law Review $^{307}$ and perhaps lent support by Professor Drahozal's recent article $^{308}$ - would invalidate subsidies paid to in-state firms subjected to an "industry-specific tax" (such as the milk tax in West Lynn Creamery), ${ }^{309}$ but uphold subsidies accompanied by only a "general tax, imposed on multiple industries, such as a sales tax or general corporate income tax." ${ }^{\prime 310}$ The key idea behind this proposed distinction is that the subsidy plus industry-specific

303. See Enrich, supra note 18, at 401 . For a critique of this race-to-the-bottom theory, sec Gillette, supra note 289 , at $16-24$.

304. H.P. Hood \& Sons v. Du Mond, 336 U.S. 525, 538 (1949).

305. See, e.g., Halliburton Oil Well Cementing Co. v. Reily, 373 U.S. 64, 72 (1963) (rejecting the creation of an "incentive to locate within Louisiana" as a legitimate justification for a higher use tax on certain out-of-state goods because "[d]isapproval of such a result is implicit in all cases dealing with tax discrimination" since every discriminatory tax "encourages an out-of-state operator to become a resident"); see also Metropolitan Life Ins. Co. v. Ward, 470 U.S. 869, 880 (1985) (stating, in applying the Equal Protection Clause, that "promotion of domestic business within a State, by discriminating against forcign corporations that wish to compete by doing business there, is not a legitimate state purpose").

306. Cf. Coenen, supra note 22 , at 475 ("If states constitutionally may use state resources to woo new businesses, then why should states not be able to use their resources to keep old businesses where they are?"); Hellerstein \& Coenen, supra note 27, at 854 (arguing that the distinction between new business and stay-at-home subsidies would create undesirable incentives). Of course, it would be possible to reformulate any business development limitation on a general prohibition on state subsidies, including business retention, as well as business creation, incentives. But such an adjustment would complicate an already complex principle and put serious pressure on the underlying distinction between "protectionist" and "nonprotectionist" subsidies.

307. See Note, supra note 31.

308. See Drahozal, supra note 33.

309. Note, supra note 31 , at 1552.

310. Id. at 1549; cf. West Lynn Creamery, Inc. v. Healy, 512 U.S. 186, 196 (1994) (noting that the Massachusetts program, like that in Bacchus Imports, involved a "tax on a single kind of good and special provisions for in-state producers"). In a lengthy article, Professor Drahozal advocates a similar approach for evaluating the constitutionality of tax credits and exemptions favoring local industry. See Drahozal, supra note 33, at 1165-67. Presumably, Professor Drahozal would gravitate toward the industry-specific-tax test in subsidy cases too, at least outside the business development context. See id. at 1129 n.9 (reserving judgment on the applicability of an industry-specific-tax tariff-likeness principle to business development incentives). For the reasons set forth in this section, however, the industry-specific-tax principle should not govern subsidy cases, and a fortiori it should not govern true tax break cases either. See also Coenen \& Hellerstein, supra note 90, at 2203-06 (discussing the critical role in tax-discrimination analysis of internalization of state "spending" within the tax system through explicit grant of credits, exemptions, or deductions). 
tax bears a close resemblance to the classic (and unconstitutional) tariff because in both cases states will find themselves unable to counter the effects of neighboring states' actions with retaliatory subsidies of their own. "In particular, the argument goes, if State $B$ retaliates against State $A$ 's true tariff or subsidy plus industry-specific tax by enacting a subsidy designed to protect State $B$ industries' competitive position in State $A$, State $A$ can counter by raising its tariff or industry-specific tax to the point at which State $B$ no longer can afford such subsidies because of "budgetary restraints." State $A$ initiates this cycle with a subsidy accompanied by a general tax. State $A$ will not be able to respond to a State $B$ retaliatory subsidy because local targets of the general tax, apart from subsidized industry members, will oppose any further increase in the State $A \operatorname{tax}^{313}$ As the note author states: "The general tax cannot convert the subsidy into a threatening functional tariff, because other in-state industries would preclude the state from increasing the tax rate, a step necessary for winning the tariff-versus-subsidy game." 314

This line of analysis-while innovative and partially rooted in policy concerns emphasized in this Article ${ }^{315}$-ultimately fails to provide a satisfactory approach for distinguishing permissible and impermissible subsidy programs. To begin with, the proposed distinction is not well-developed. For example, how does it operate when the challenged subsidy is enacted at another time than the industry-specific tax? The majority in West Lynn Creamery lent this "simultaneity" factor much significance. ${ }^{316}$ Yet a principle built solely on the distinction between "industry-specific" and "general" tax cases would seem to take no account of this factor or of a number of other factors that courts are likely to find important. ${ }^{317}$

311. See Note, supra note 31 , at $1544-48$ (discussing tanffs); $t d$ at 1552-53 (discussing a subsidy coupled with an industry-specific tax).

312. Id. at 1551 .

313. See id. at 1550-52.

314. Id. at 1550 .

315. See infra text accompanying notes 327.328

316. See West Lynn Creamery. Inc. v. Healy, 512 U.S. 186, 199-201 (1994); see also supra notes 59 . 61 and accompanying text. For an explanation of why the Cour properly considered this factor significant. see infra notes $410-411$ and accompanying text.

317. See Coenen \& Hellerstein, supra note 90, at $2195-227$ (discussing and defending vanous linkage criteria). The Harvard note author also posits that the majonty in West Lvin Creamern at least might have been prepared to decide the case differently if the Massachuselts milk taxes had gone into the general treasury, rather than a segregated fund. See Note, supra note 31. at 1538. This possibility seems farfetched. however, particularly since the majority's analysis-in pointed contrast to that of Justice Scalia, who (in vigorously criticizing the majority) specifically endorsed this distınction. see liest Lynn Creamery. S12 U.S. at 210-11 (Scalia, J., concurring); see also supra note 238 and accompanying texl-did nol focus on the presence of a segregated fund at all. At the least, the note author missteps to the extent he suggests that Professor Hellerstein and I "argued unambiguously" for the segregated fund pnnciple embraced by Justice Scalia. Note, supra note 31, at 1539 (citing Hellerstein \& Coenen, supra note 27. at 837-45). In our Comell Law Review article, we concurred with the West Lyn Creamen majonty's view that "courns should stnke down only those subsidies that operate . . . as discriminatory de facto rebates of an idenufiable state tax." 
More basically, it is wrong to equate with tariffs only those subsidies linked to industry-specific taxes. Indeed, we have already seen that some combinations of a subsidy and a general tax will very closely approximate true protective tariffs. ${ }^{318}$ On the other hand, many subsidies that accompany industry-specific taxes-namely, all those subsidies that go to only some instate members of the taxed industry-present political dynamics unlike those that surround the use of tariffs. In particular, it is wrong to suppose, as the note author apparently would, ${ }^{319}$ that our hypothetical State $A$ will simply raise its industry-specific tax (just as it would raise a tariff) if neighboring State $B$ responds to the State $A$ subsidy and industry-specific tax with a retaliatory subsidy for its own industry members. If there are taxed industry members within State $A$ that do not receive the subsidy, they are certain to oppose any such tax increase. ${ }^{320}$ In these circumstances, it is questionable to assert that "the state can raise an industry-specific tax rate more freely than a general one." 321 Indeed, just the opposite may be the case if the principle holds true that "the political process responds much better to concentrated interests than to dispersed ones." 322

Finally, the distinction between a "specific tax" and a "general tax" is subject to criticism on doctrinal grounds. In Westinghouse, ${ }^{323}$ for example, the Court struck down a business development incentive, in the form of tax relief, that accompanied a general corporate income tax. In addition, although the Court in both Bacchus Imports ${ }^{324}$ and New Energy ${ }^{325}$ invalidated tax relief that accompanied industry-specific taxes, analysis of those opinions suggests that this fact was irrelevant to the Court. There is simply no reason to believe that the Court in Bacchus Imports would have reached a different result had the same facially discriminatory tax exemption for local fruit wine

id. at 838 , and specifically identified one category of potentially invalid and tax-tied subsidy paid from the general fund, see id. at 863-65. We did not endorse as analytically significant in any context the bright line segregated fund principle advocated by Justice Scalia.

318. See supra note 98 and accompanying text.

319. See Note, supra note 31 , at 1552.

320. See Coenen \& Hellerstein, supra note 90, at 2199-200, 2202, 2209-10.

321. Note, supra note 31 , at 1552 .

322. Collins, supra note 27 , at 68-69. In addition, the Harvard note author's approach is built on the expectation that states engaged in protectionism and retaliation will act with a high level of subtlety and refinement. Suffice it to say that the author's "game-theoretical analysis," Note, supra note 31, at 1544, is not likely to be replicated in the rough and tumble world of raw trade-warfare politics. This is all the more true because questions about whom to tax and subsidize-and about how to anticipate and respond to the moves of neighboring states-invariably arise against a complex backdrop of competing claims made by various industry members, producers of substitutes, suppliers of raw materials, local consumers, taxpayers, and competing would-be beneficiaries of state spending programs.

323. Westinghouse Elec. Corp. v. Tully, 466 U.S. 388 (1984). Notably, in Camps Newfound/Owatonna, Inc. v. Town of Harrison, 117 S. Ct. 1590 (1997), the Court again invalidated discriminatory tax relief, even though afforded against a general property tax.

324. Bacchus Imports, Ltd. v. Dias, 468 U.S. 263 (1984).

325. New Energy v. Limbach, 486 U.S. 269 (1988). 
sales operated to reduce a "general" corporate income tax instead of an "industry-specific" liquor wholesaling tax. ${ }^{326}$ And if that is so, the argument for recognizing the distinction between a specific tax and a general tax seems in tension with established doctrine.

Despite these criticisms, the proposed specific-tax principle probably reflects a valid underlying concern. In particular, the more industry-specific a tax is the more likely it may be that a related subsidy will have the linking characteristic (elsewhere called "universality of scope"327) that is present when a subsidy favors all in-state members of a taxed group. ${ }^{328}$ But universality of scope is not always present in industry-specific-tax cases, and it is not, in any event, the only relevant indicator of tax-subsidy linkage. In short, a prohibitory rule that focuses exclusively on a subsidy's relation to an industry-specific tax is, in the end, oversimplified and misconceived.

\section{B. Toward a Policy-Driven Principle for Distinguishing Permissible and Impermissible Subsidies}

This review of possible strategies for distinguishing constitutional from unconstitutional subsidies reminds us of an important proposition. Most serious theorists who have looked at the question have rejected the view that the Cour should invalidate monetary subsidies in wholesale fashion. There appears instead to be a felt need to sustain many state subsidy programs, while nonetheless imposing some limiting principle upon them. Where should this

326. See infra notes 365-370 and accompanying text. After all. the basic principle that controlled the case had nothing to do with the industry-spectfic character of the stale exaction. Inslead, the disposilive rule was that "[n]o state, consistent with the Commerce Clause, may impose a tax which discnminates against interstate commerce." Bacchus Imports. 468 U.S. at 268 (intemal quotation marks omutled). That pnnctple has always been applied to both general and industry-specific taxes. See. e.g. Associated Indus. v. Lohman. 511 U.S. 641 (1994) (sales and use tax): Hallibunon Oil Well Cementıng Co. v. Reily. 373 U S G (1963) (sales and use tax); I.M. Darnell \& Son v. City of Memphis, 208 U S. 113 (1908) (siles tax) Moreover, in applying this principle, the Court has never focused on the number of in-state firms that are subject to the challenged tax. Instead, the Coun has consistently proclaimed that, if a tax favors some in-stale activities, goods, or entities, “.'[w]e need not know how unequal the [1]ax is before concluding that it unconstitutionally discriminates." Bacchus Imports, 468 U.S. at 269 (quoung Maryland v Louisiana. 451 U.S. 725, 760 (1981)); see also Wolfe, supra note 266. at 764 ("Taxes and exactions that discrnminate against interstate commerce, even when composed in part of laxes on inirastate commetce, are unconstitutional.").

For these reasons, it is hardly surprising that the Court in Camps Newfound Owatonna ciled Bacchus Imports for the broad proposition that "discriminatory tax exemptions (designed to] encouragle] the growth of local trade ... are impermissible." Camps Newfound/Owatonna. $117 \mathrm{~S}$. Ct. at 1604 (ciung Bacchus Imports, 468 U.S. at 273). Indeed, Camps Newfound/Owatonna involved a challenge to discriminatory tax exemption (afforded only to nonprofit corporations that dealt pnmanly with local residents) from a generally applicable property tax. The Court, relying on Bacchus and other cases, had no difficulty stnking this tax exemption down and clearly perceived no distincuon at all between an excmption from a general tax and an exemption from an industry-specific tax.

327. Coenen \& Hellerstein, supra note 90, at 2202.

328. See id. at 2199-200. 
limiting principle come from? The answer to this question, it turns out, flows from the basic thesis of Parts I and II of this Article.

In those parts, after all, we saw that both Supreme Court precedent and a raft of functional considerations support the general proposition that discriminatory subsidies are lawful even though discriminatory tax breaks are not. This overarching conclusion suggests the essential issue posed in any Commerce Clause subsidy case: Is the challenged state payment more properly characterized as a subsidy or as tax relief? Perhaps the most telling feature of the West Lynn Creamery case is that all nine Justices proceeded from the premise that this question was the right one to ask. Thus, according to the majority and concurring opinions, the problem at hand was whether the milk payments should be characterized as a tax "rebate." ${ }^{, 329}$ Even the dissenters voiced no disagreement with the view that a discriminatory tax rebate would violate the dormant Commerce Clause; instead, they disagreed-because the payers of the tax were not the recipients of the subsidy - with the majority's conclusion that the rebate label applied. ${ }^{330}$

In short, there was unanimity in West Lynn Creamery that, in cases of this kind, courts should focus on whether there exists a strong enough link between the challenged subsidy and some related tax to treat the subsidy as a de facto tax break. ${ }^{331}$ What split the Court apart was how to decide whether such a linkage was present. The challenge left behind by West Lynn Creamery is therefore clear: to determine how courts should go about deciding whether any particular state subsidy is sufficiently interconnected with a particular state tax to trigger application of the dormant Commerce Clause prohibition on discriminatory taxation.

As courts consider subsidy-tax linkage problems in Commerce Clause cases, they should recognize that comparable questions have arisen, and will continue to arise, in a variety of constitutional settings. Professor Hellerstein and $I$ have developed this point elsewhere by showing that courts confront linkage issues in applying, not only the dormant Commerce Clause, but also the intergovernmental tax immunity doctrine, the Privileges and Immunities Clause, and the uniformity and equality provisions of state constitutions. ${ }^{332}$ In all of these contexts, certain factors suggest illicit linkage. These factors include simultaneity of enactment of the tax and payment programs, ${ }^{333}$

329. West Lynn Creamery, Inc. v. Healy, 512 U.S. 186, 197 (1994); id. at 210 (Scalia, J., concurring); see supra text accompanying notes 235 and 257.

330. See supra text accompanying note 255 .

331. See Coenen \& Hellerstein, supra note 90 , at $2172-73$ (analyzing the Justices' different approachcs to this issue).

332. See id. at 2176-84 (intergovemmental tax immunity); id. at 2196-97 (Privileges and Immunitics Clause); id. at $2184-89$ (uniformity and equality provisions).

333. See id. at 2198-99. 
computational connectedness, ${ }^{334}$ and a correspondence between the constitutionally protected class of taxpayers and those groups excluded from the tax-relieving benefits of the payment program. ${ }^{335}$ The most difficult and interesting linkage cases, however, require courts to draw on the distinctive policies that surround the particular constitutional provision at issue. ${ }^{336}$

What underlying policies should courts consult in applying the "law of linkage" in the dormant Commerce Clause setting? Upon reflection, the answer to this question is apparent. I have already devoted much energy to identifying the cluster of justifications that underpin the basic Commerce Clause distinction between subsidies and tax breaks. ${ }^{337}$ These considerations, as we have seen, center on: (1) conventional notions of faimess that support a broad state power to channel a state's own property to a state's own residents; (2) the special force of federalism arguments in the subsidy context; (3) the reduced risk to free interstate trade presented by subsidies (because of their distinctive visibility, susceptibility to periodic review, intelligibility and the like); and (4) the historical focus of the Constitution's Framers not on state subsidies, but on commerce-threatening state tax schemes. Courts should consult these same factors as they grapple with whether particular payment programs fall on the ordinary subsidy or the discriminatory tax break side of the constitutional line. ${ }^{338}$

These four factors have not been made from whole cloth. Instead, the Supreme Court itself has drawn on these considerations, or considerations very much like them, in the parallel set of cases involving the so-called "market participant exception" to the dormant Commerce Clause rule. ${ }^{339}$ A common thread ties the market participant and subsidy cases together; at bottom, each type of case concerns choices about how a state will distribute its own resources. ${ }^{340}$ As a result, it is sensible and unsurprising that, in both contexts, a like set of referents should guide judicial decisionmaking.

334. See id. at 2200 .

335. See id. at $2199-200$.

336. See id. at 2201-02, 2218, 2223-27.

337. See supra Section II.B.

338. Cf. Drahozal, supra note 33, at 1144 ("The problem then becomes one of characterization is a challenged state law more like a lawful subsidy or more like an unlawful tanif'")

339. See sources cited supra note 22.

340. See, e.g., Kline, supra note 22, at 390-91 (reasoning that state sales. purehases, or substulics should be treated in like fashion because they all involve "spending or . . . property. goods. or services owned by the state"); see also Smith, supra notc 289. at 1222 (notıng "That what the Coun may inuly have in mind [in its market participant cases] is the special character of state programs for disinbutung its own money or resources"); Varat, supra note 22. al 493. 552 (advocalung a broader state-propenty-distnbution principle that includes, but also reaches beyond, the market participant rule and that covers subsidy programs). 


\section{APPLying THE POLICY-BASEd LiNKage METHOdOLOGY}

The policy-centered approach to linkage problems proposed in Part IV can provide a tool for evaluating future cases only if it squares with the result in West Lynn Creamery itself. A necessary starting point for assessing this approach thus involves its application to the facts of that case. In Section V.A, I show that application of a policy-guided linkage analysis fully comports with the ruling in West Lynn Creamery. Then, in Section V.B, I analyze under this policy-centered linkage structure a variety of subsidy programs that have been, or may soon be, litigated in the lower courts.

\section{A. A Better Analysis for West Lynn Creamery}

As we have seen, both Justice Stevens and Justice Scalia properly focused in West Lynn Creamery on whether a fatal linkage existed between the Massachusetts milk subsidy and the Massachusetts milk tax. ${ }^{341}$ As we also have seen, in finding a fatal linkage both Justices offered question-begging or otherwise assailable lines of reasoning. ${ }^{342}$ The Justices did not offer analyses based on the four concerns that, as a general matter, distinguish subsidies from tax breaks. Such a systematic, policy-driven analysis reveals why the Massachusetts milk program was invalid and helps show how courts should approach future cases.

\section{Fairness}

A state's residents generally should be free to channel state subsidies to themselves. Why? Because, as a rule, it is fair to "limit[] benefits generated by a state program to those who fund the state treasury and whom the State was created to serve." ${ }^{343}$ This sow-and-reap rationale applied only tenuously in

341. See supra text accompanying notes 47-52.

342. See supra Sections III.A-B.

343. Reeves, Inc. v. Stake, 447 U.S. 429, 442 (1980); see also, e.g., White v. Massachusetts Council of Constr. Employers, Inc., 460 U.S. 204, $214-15$ (1983) (allowing a hiring preference for local workers and stating that "[i]nsofar as the city expended only its own funds in entering into construction contracts for public projects, it was a market participant"); McCready v. Virginia, 94 U.S. 391,396 (1877) (finding that the state's citizens, "and they alone, owned the property to be sold or used, and they alone had the power to dispose of it as they saw fit"); Kline, supra note 22, at 350 ("Central [to Reeves] was a belief that the states have a heightened sovereign claim when redistributing to their residents benefits made available through the local fisk [sic]."); Regan, supra note 4, at 1113 ("A state does have a special relationship to its own citizens. Alaska may provide that only Alaskans . . . share in the distribution of the state's oil royalties. Such legislation is not hostile to non-Alaskans in the way protectionism is hostile. It takes nothing away from non-Alaskans that we would normally think they have as much right to as Alaskans have."). See generally Coenen, supra note 22, at 421-26 (describing the Court's and commentators' recognition of a fairness-based rationale). Of course, there is often a measure of crudeness to the sow-and-reap principle, since many nonresidents pay state taxes. Professor Varat argues at length that the sow-and-reap principle 
West Lynn Creamery because, in substance, Massachusetts residents had not "combined to produce" the fund out of which the challenged subsidies were paid. ${ }^{344}$ Instead, the state nominally imposed a tax on both in-state and outof-state milk and created a "wash" with respect to the in-state milk tax payments by returning them to in-state milk producers, and thus in effect captured only the tax on out-of-state milk sales for redistribution to in-state producers. ${ }^{345}$ It is one thing to distribute to state residents monies that reflect "a return of capital" 1346 that "a state's citizens . . created or preserved." It is quite another thing, however, for the state to redirect to favored in-staters a specified pool of monies extracted, for that very purpose, from the sale of out-of-state goods. ${ }^{348}$ In such circumstances, Massachusetts residents were not reaping where they had sown; they were robbing the out-of-state Peter to pay the in-state Paul. ${ }^{349}$

\section{Federalism}

The Court's general discomfort with invalidating state subsidies also stems from concerns about safeguarding "our Federalism." 350 As a leading scholar of the dormant Commerce Clause has explained, "[T]o bar the states from making any distinctions between in-state and out-of-state interests in distributing state resources [would threaten] the essential fabric of our constitutional plan." ${ }^{351}$ That observation is true in part because foreclosing resident preferences in the grant of state monies would contravene principles of federalism by impeding state-by-state development of specialized programs

is nonetheless legitimate in light of the special tax-paying responstbulutues that come thith state residency See Varat, supra note 22, at 528-30 (noting the "general validity of using residence to approximate the group responsible for creating the state's benefits"): of. Ennch. supra note 18. at 452 ("Yet in the context of state taxation, in-state and out-of-state businesses simply are not similarly situated Indeed, the Commerce Clause itself dictates that they cannot be. because it requires that state taxes apply only to activities having a substantial nexus with the taxing statc.").

344. Varat, supra note 22, at $\$ 23$.

345. See supra text accompanying note 194: see also ERWIN CHEMERINSKY. CONSTtT TIONAL. LAW PRINCIPLES AND POLICIES $\S 5.4 .4$, at 347 (1997) ("In essence, the state was taxing both in-staters and outof-staters, but in effect refunding the taxes paid by in-staters through the subsidy system ")

346. Anson \& Schenkkan, supra note 22. at 89.

347. TRIBE, supra note $4, \S 6-35$, at 539 .

348. Cf. Varat, supra note 22, at 545 n.205 (noting that a program "purportung to tax in-state and outof-state businesses equally and then subsidizing the in-state businesses... . clearly would amount to discriminatory taxation").

349. Cf. Bair, supra note 22, at 2422-23 (notung that the sow-and-reap ratuonale is inapplicable when state monies that are paid out "come from ... taxes or licensing fees pasd by nontesidents")

350. Younger v. Harris, 401 U.S. 37, 4 (1971). For some of the many vindicalions of federalism interests in recent years, see United States v: Prutz, 117 S. Cl. 2365 (1997). Unured States v. Lopez. 514 U.S. 549 (1995); New York v. United States, 505 U.S. 14t (1992); and Gregory v Ashcrofi. 501 US 452 (1991).

351. Walter Hellerstein, Hughes v. Oklahoma: The Court, the Commerce Clause, and Stute Control of Natural Resources, 1979 SUP. CT. REV. 51. 75: see also sources cited supra note 107 
to address "diverse local needs." 352 If farmers in Nebraska need financial help, for example, it seems sensible that Nebraskans, through their government, should be free to supply it. The Nebraska legislature, however, will hesitate to offer such aid if the only way it can do so is by subsidizing large numbers of out-of-state farmers as well. ${ }^{353}$

These sorts of concerns about impeding local fiscal autonomy, however, offered limited help to the defenders of the program struck down in West Lynn Creamery. That program, after all, reflected a desire to aid the state's ailing dairy industry through cash subsidization. If this were a genuinely deserving need, however, Massachusetts could have addressed it-and still can address it - with funds paid by all taxpayers by way of ordinary exactions unlinked to subsidy payments. ${ }^{354}$ Given this ready and equally efficacious alternative, it is hard to say that invalidation of Massachusetts's peculiar mode of subsidization disabled the state from fashioning "effective . . programs for solving local problems." ${ }^{\text {,35 }}$

\section{Political Processes}

As we have seen, for a host of reasons state subsidies in general are less likely to threaten Commerce Clause values than discriminatory tax credits, exemptions, or deductions. In particular, a built-in brake on the undue proliferation of subsidies exists because they inflict on state residents highly visible costs that are easy to understand, carry with them potentially prohibitive administrative burdens, and are regularly subject to reappraisal in the annual budgeting process. ${ }^{356}$ For all these reasons, "[w]here the funds for a subsidy or preference benefitting some state residents come out of the state treasury,

352. GUNTHER, supra note 247 , at 67 ; see also TRIBE, supra note $4, \$ 6-11$, at 434 (explaining that the market participant rule "allows state and local governments the freedom to experiment with different packages of benefits for their citizens without fear that they will have to share the contents with everyone else"); Collins, supra note 27, at 79 (noting that "[p]olicy reasons in favor of . . . protectionist subsidics" include the desire not to "curtail useful state undertakings"); Regan, stipra note 4, at 1194 ("many [useful] programs would not exist if the state could not channel the primary benefits to locals"); Varat, supra note 22 , at 522 ("When the Framers provided for concurrent federal and state taxing, spending, and regulatory powers, they sanctioned a diversity of policies among the states.").

353. As Maltz notes:

[A]ssume that a state considered its cantaloupe industry critical to the economic health of the state, and thus chose to subsidize domestic cantaloupe production. Few would deny that the state could do so without also subsidizing out-of-state cantaloupe producers who wished to sell cantaloupes in the state, even though the subsidy for domestic producers would give them a competitive advantage in the marketplace.

Maltz, supra note 106, at 68.

354. See Patterson, supra note 18 , at $1024 \mathrm{n} .310$ ("The states may reach the desired ends of the pricing scheme by subsidizing the dairy farmers from the state's general fund.").

355. Reeves, Inc. v. Stake, 447 U.S. 429,441 (1980).

356. See supra notes 112-150 and accompanying text. 
reviewing courts might assume that the state legislature has considered the program's] burdens and benefits" more carefully than when it enacts a tax law that favors local businesses. ${ }^{357}$

Massachusetts's milk payments, however, did not come out of "the state treasury"; instead, they were drawn from the pooled proceeds of a specific tax established as an inseparable part of the subsidy program. While the ordinary subsidy is subject to heightened visibility because it is paid by way of "budgeted spending"358 out of "public funds," 359 Massachusetts set up a self-funding tax-and-spending program as a unitary package, solely to channel earmarked tax revenues to local dairy farmers. Thus, as far as built-in political checks on protectionism go, the payments at issue in West Lynn Creamery operated much more like tax breaks than typical monetary subsidies.

\section{Considerations of Form}

Given the original tax-related purposes of the Commerce Clause, the case for finding a fatal linkage is strong if a subsidy provides in substance for relief from a particular identifiable tax. In West Lymn Creamery, Justice Stevens focused on this point when he described the state's subsidy payments as a "rebate" of the Massachusetts milk levy. ${ }^{360}$ Likewise, Justice Scalia reasoned that it was Massachusetts's award of a tax "refund" that placed its program in the endangered tariff-and-tax-break category, rather than on the unendangered ordinary subsidy list. ${ }^{361}$

Both Justices were right in their underlying assumption that a discriminatory tax rebate offends the dormant Commerce Clause principle. A tax rebate, after all, is a tax break: It provides relief from a tax to in-staters, but not to out-of-staters, and by reason of that disparate treatment, it offends the ban on discriminatory taxation. ${ }^{362}$

357. Levmore, supra note 39 , at 585 . The greater vulnerability of subsidies in the poltical process is suggested by a recent decision by budget-balancers in Congress to focus attention on cash grants rather than tax breaks. See Tumulty, supra note 26, at 47 (")[House Budget Committe Chatr John) Kasich has already given up at least half the battle. This year the Budget Committee will focus its cffort cntirely on direct payments the government makes to busıness, ignonng the estimated $\$ 50$ billion a year Washington grants in tax breaks.").

358. Spending by Not Taxing, ECONOMIST, Jan. 23. 1988, at 51,51

359. Gergen, supra note 22, at 1135; see also Walz v. Tax Comm'n, 397 U S 664. 690 (1970) (Brennan, J., concurring) (noting that subsidies come from "resources exacted from taxpayers as a whole"), quoted in Texas Monthly, Inc. v. Bullock. 489 U.S. 1. 35 (1989) (Scalıa, J., dissenting): and Committec for Pub. Educ. \& Religious Liberty v. Nyquist, 413 U.S. 756, 807 (1973) (Rehnquist. J . dissenung in part)

360. West Lynn Creamery, Inc. v. Healy, 512 U.S. 186. 197 (1994); see supra text accompanyıng note 48. 235.

361. West Lynn Creamen, 512 U.S. at 210 (Scal1a, J.. concurnng): see supra tcxt accompanyıng note

362. See Coenen \& Hellerstein, supra note 90. at 2204 
Although there was room to argue about whether the Massachusetts milk payments operated just like typical tax rebates, ${ }^{363}$ a seven-member majority of the Court concluded that they came close enough to justify application of the "rebate" label. In other words, seven Justices viewed the case as no different from one in which dealers paid taxes on all sold milk and then themselves received rebates from the state only for those taxes paid on Massachusetts products. On this view, the Massachusetts program bore an unmistakable resemblance to a true tariff. ${ }^{364}$

Indeed, for two separate reasons, the anti-tariff principle applied to the program at issue in West Lynn Creamery with distinctive force. First, like a tariff, the Massachusetts program in effect put no tax burden on anything produced by any in-stater. A useful point of comparison is Bacchus Imports, ${ }^{365}$ which concerned an exemption for sales of fruit wine and okolehao produced in Hawaii from the state's generally applicable excise tax on wholesale transfers of alcohol. In West Lynn Creamery, the Court explained its earlier invalidation of this Hawaii tax scheme in the following words: "By granting a tax exemption for local products, Hawaii in effect created a protective tariff. Goods produced out of State were taxed, but those produced in-state were subject to no net tax." 366 It was only half true, however, to say that goods "produced in-state were subject to no net tax"; after all, every alcoholic beverage produced in Hawaii was fully taxable unless it was fruit wine or okolehao. ${ }^{367}$

In West Lynn Creamery, by contrast, the tax was levied on milk but not on any other beverages produced in Massachusetts, so that the rebate served to protect, at least indirectly, all of the domestic product otherwise subject to the tax. The case, in other words, would have been different had the subsidy gone only to Massachusetts producers of Holstein milk, but not to Massachusetts producers of Jersey or Guernsey milk. In fact, however, Massachusetts producers of any type of milk were eligible to receive the state's "rebate." ${ }^{368}$ Bacchus Imports was thus not only "most similar"369 to West

363. See supra text accompanying notes $255-265$.

364. Cf. Drahozal, supra note 33, at 1148 ("Because the tax necessary to finance the subsidy will increase the price of widgets and reduce widget consumption, the subsidy will now have the same consumption loss-as well as the same production loss-as a tariff.").

365. Bacchus Imports, Ltd. v. Dias, 468 U.S. 263 (1984).

366. West Lynn Creamery, 512 U.S. at 197.

367. See Bacchus Imports, 468 U.S. at 265 (noting that "[I]ocally produced sake and fruit liqueurs are not exempted from the tax"); id. at 271 (finding the exemption discriminatory "in that it applics only to locally produced beverages, even though it does not apply to all such products").

368. See West Lynn Creamery, 572 U.S. at 188 (describing the pricing order as applying to "all fluid milk").

369. Id. at 196. 
Lynn Creamery; it supplied an a fortiori argument for invalidating the Massachusetts program. ${ }^{370}$

Second, the tariff-like character of the Massachusetts program was magnified by the state's dispersal of all funds collected through the milk tax back to in-state milk producers. ${ }^{371}$ In fact, as a result of this wrinkle in the Massachusetts program, in-state producers did even better than they would have done under a true tariff program: They not only got back all tax payments made on their own milk, but received in addition all tax payments attributable to out-of-state milk. The Massachusetts program thus hit out-of-state milk producers with a double-whammy worse than a tariff. In practical effect, the program placed a tariff on the imports of out-of-state producers and then turned every tariff penny paid directly over to their in-state competitors. ${ }^{372}$

The majority in West Lynn Creamery never mentioned the first of these features of the Massachusetts program and did not focus on the second. ${ }^{373}$ These distinctive characteristics, however, provided especially potent reasons for subjecting the Massachusetts program to the anti-tariff principle at the core of the dormant Commerce Clause.

\section{B. Deciding Other Subsidy Cases}

The foregoing discussion confirms two key points. First, the ordinary subsidy payable from the general treasury remains constitutional. ${ }^{374}$ Second,

370. Indeed, this argument may have been strengthened by the fact that West Lynn Creameny. unlike Bacchus Imports, involved milk. Okolehao is probably tasty. but there are many substututes for it. So too with ethanol, most foodstuffs, and other household goods. Milk, however, has a distınctive appeal linked to its perceived contributions to good health (as well as its usefulness as a complement to breakfast cereal). It thus may lack strong competitive substitutes, so that subsidizing mılk hurts out-of-state milk producers. while affecting in-state makers of other products little, if at all. See Nebbia v. New York. 291 U.S. 502. 516 (1934) ("Milk is an essential item of diet."); id. at 557 (McReynolds, J., dissenung) (descnbıng mulk as "a necessity of life"); Patterson, supra note 18, at 1012 ("Milk. for instance, is likely to have a faurly inelastic demand because it has no close substitutes."). If these assumptions are true, a mulk subsidy-cien standing alone-would "behave" much like a tariff (paricularly from a political process angle) for the same reason that a tax exemption behaves most like a tariff when no substututes for the exempled product are made in the state. See supra note 99 . In particular, because such a subsidy would significantly harm only out-of-state milk producers and not significantly affect in-state producers of subsutute products, there would be no "major in-state interest adversely affected" to provide "a powerful safeguard against legislative abuse." Minnesota v. Clover Leaf Creamery Co., 449 U.S. 456. 473 n.17 (1981). Of course. I make no claim that the critical assumptions made here about the availability of substitutes for milk are accurate: 1 leave that matter for investigation by economists and nutntionists. The key legal point is that some forms of tax-related subsidies for local industry will operate more like tanffs than others.

371. See supra text accompanying note 47.

372. See Drahozal, supra note 33, at 1162 ("Effectuvely, the pncing order was a tanff in which the tariff revenue was paid to in-state producers-hardly a saving feature.").

373. See West Lynn Creamery, 512 U.S. at 194-95.

374. See also Drahozal, supra note 33, at 1138 ("Although the Coun made clear that it was not deciding whether a subsidy funded from a state's general revenues would be lawful, such a conclusion seems to follow from its analysis."): Walter Hellerstetn. West Lynn Creamery Inc. v. Healy and the Constitutionality of State Tax Incentives: A Prelimunan Analysts. 7 STATE TAX NOTES 1182. 1186 (1994) 
the Court reached the right result in deeming unconstitutional the closely connected tax-and-subsidy package at issue in West Lynn Creamery. But what about subsidy programs that fall between these poles? ?75

In this final section, I consider whether actual or predictable adaptations of the program at issue in West Lynn Creamery should survive dormant Commerce Clause attack. Subjecting such subsidies to the policy-centered scrutiny proposed here reveals how this approach can produce consistent and sensible results. I look at four separate variations of the West Lynn Creamery scheme: (1) the program in which most subsidy-funding taxes are paid on instate, as opposed to out-of-state, products; (2) the program in which tax payments are not put in a segregated fund, but instead go into and back out of the state's general treasury; (3) the program that involves a tax and a subsidy that are not simultaneously enacted; and (4) the program upheld in Cumberland Farms, Inc. v. Mahany (Cumberland Farms II), ${ }^{376}$ which was designed specifically to escape the clutches of the West Lynn Creamery ruling. ${ }^{377}$

\section{The Source of Subsidy Money}

In Cumberland Farms, Inc. v. LaFaver (Cumberland Farms ), ${ }^{378}$ the First Circuit confronted a Maine tax-and-subsidy program nearly identical to the program invalidated in West Lynn Creamery. There was, however, one key difference. Because Maine-unlike Massachusetts-is not a heavy milk

(noting that states apparently can avoid West Lynn Creamery by funding subsidies out of general revenues).

375. Two recent cases out of Minnesota, for example, involved unusual applications of the West Lynn Creamery principle. In Zenith/Kremer Waste Systems, Inc. $v$. Western Lake Superior Sanitary District, 558 N.W.2d 288 (Minn. Ct. App. 1997), the court invalidated a generally applicable waste management fec imposed on all waste handled within the district, regardless of where the waste was hauled because the feo was imposed to offset a recent tipping-charge reduction at the local waste-processing facility. Following West Lynn Creamery, the court deemed the tipping-charge reduction a rebate of the waste management fec that was discriminatorily denied to those who dealt with out-of-state landfills. Likewise, the court in Sanifill, Inc. v. Kandiyohi County, 559 N.W.2d 111 (Minn. Ct. App. 1997), invalidated a similar program in which the reduction of the tipping charge and the imposition of a waste management fee were put in place simultaneously.

376. 943 F. Supp. 83 (D. Me. 1996).

377. Any rule that sorts between good and bad subsidies will raise a preliminary characterization question about whether the case involves a "subsidy" at all. For example, in Alliance for Clean Coal $v$. Miller, 44 F.3d 591 (7th Cir. 1995), Illinois forced coal-burning power plants to install "scrubbers" needed to burn high-sulfur Illinois coal in an effort to support local coal producers. The state, however, simultaneously permitted the utility to pass along the cost of adding scrubbers to ratepayers through fec increases. Judge Cudahy, in a concurring opinion, wrote: "The ratepayers are substantially coterminous with the taxpayers and a mandate to place a charge on the ratepayers is in economic effect functionally equivalent to a subsidy financed from general revenues." Id. at 597 (Cudahy, J., concurring). Not so. Utilities, after all, had to install scrubbers; thus the state program involved far more than awarding "subsidies" as we normally think of them. In other respects, too, the challenged program departed markedly from a subsidy. In particular, no budgeted spending was necessary to effectuate the program. Indeed, the state itself turned over no money at all to anyone.

378. 33 F.3d 1 (lst Cir. 1994). 
importer, most of the tax proceeds used to subsidize Maine dairy farmers had been generated by dealer sales of in-state milk. In Cumberland Farms $I$, the court found this fact inconsequential, ${ }^{379}$ and it was right to do so under the policy-centered analysis offered here. Indeed, each of our four policy-based linkage factors supports the conclusion that this feature of the Maine program did not serve to distinguish Cumberland Farms I from the West Lynn Creamery case.

First, in Cumberland Farms I, the return of in-state milk taxes to in-state milk producers created exactly the same sort of financial "wash" that was present in West Lynn Creamery. As a result, in both cases, it was the diversion of monies from sales of out-of-state milk to the benefit of in-staters that was constitutionally significant. And, with respect to those funds, Maine-like Massachusetts-was not reaping where it had sown. ${ }^{380}$

Second, in the Maine case, just as in the Massachusetts case, federalism interests were muted because the same opportunity existed to address local needs with a subsidy funded with dollars genuinely drawn from the general treasury. In other words, in Cumberland Farms I, no less than in West Lynn Creamery, a "less restrictive alternative"-in the form of subsidies funded with truly public revenues, rather than revenues essentially captured from sales of out-of-state milk-was available to aid local milk producers if in fact they needed government support. ${ }^{381}$

Third, in both cases, the ordinary brakes on excessive subsidization could not and did not take hold. In particular, in each state, simultaneous enactment of the local dairy farmer subsidy and the closely related across-the-board milk tax removed the built-in checks that impede the enactment of stand-alone subsidies. ${ }^{382}$ Also, in each case, the unitary, self-funding character of the program made legislative redirection of tax proceeds to any use other than local dairy farmer subsidization improbable. ${ }^{383}$

Fourth, in both cases, the resemblance of the overall program to a prohibited protective tariff was strong. Indeed, the Cumberland Farms I program was marked by exactly the same tariff-exacerbating problems present in West Lynn Creamery: (1) The milk support program adversely affected no other in-state product; ${ }^{384}$ and (2) the state not only extracted de facto tariffs from out-of-state milk, but it also turned those funds over to in-state competitors of the tariff-paying out-of-staters. ${ }^{385}$ To be sure, Maine extracted

379. See id. at $1-2$.

380. See supra Subsection V.A.1.

381. See supra text accompanying notes 354-355.

382. See Coenen \& Hellerstein, supra note 90 , at 2198.

383. See supra text accompanying notes 358-359.

384. See supra notes $365-370$ and accompanying text.

385. See supra text accompanying notes $371-372$. 
fewer duties than Massachusetts from milk produced on out-of-state farms. But a tariff is no less a tariff because it operates on only a limited number of outof-state producers or products. The "size and number of in-state and out-ofstate firms" does not matter, ${ }^{386}$ because "[w]e need not know how unequal the $[\mathrm{t}] \mathrm{ax}$ is before concluding that it unconstitutionally discriminates." 387

\section{The Segregated Fund}

Assume that Massachusetts adopted exactly the same program at issue in West Lynn Creamery, but without a "segregated fund." The program would thus place payments directly into (and take subsidy payments directly out of) the state's general treasury. ${ }^{388}$ For Justice Scalia, this change in facts apparently would have produced a change in result. ${ }^{389}$ For Justice Stevens, however, the state's use of a segregated fund did not play a critical role. So whose lead should lower courts follow, Justice Stevens's or Justice Scalia's? The proper answer, of course, is that they should follow Justice Stevens, for he had five votes, while Justice Scalia had only two. No less important, however, a policy-centered analysis confirms that Justice Stevens was right to conclude that the use of a segregated fund should not be an indispensable condition for striking down the sort of program involved in West Lynn Creamery.

\section{a. Fairness and Federalism}

Is a segregated fund program distinguishable from a nonsegregated fund program on the basis of reap-and-sow or federalism concerns? Perhaps it would be cleaner to say the following: There can never be such a thing as a de facto segregated fund; general fund payments-whatever their connection to even the most focused, single-industry tax-must be deemed to come from the public as a whole; and commingling the proceeds of a special tax in the general fund necessarily uncouples the tax from even a simultaneously enacted subsidy. But can it be that a lack of fund segregation always disassociates a subsidy and a tax? What if, for example, Massachusetts's subsidy payments

386. New Energy Co. v. Limbach, 486 U.S. 269, 276-77 (1988); accord, e.g., Wyoming v. Oklahoma, 502 U.S. 437, 455-56 (1992); cf. Regan, supra note 4, at 1258 (asserting that the Court did "not seen to care in Baldwin how much of New York's milk comes from out of state" and that "later cases suggest that such percentages are not determinative" (discussing Baldwin v. G.A.F. Seelig, 294 U.S. 511 (1935))).

387. Maryland v. Louisiana, 451 U.S. 725,760 (1981).

388. Cf. Patterson, supra note 18, at 1024 ("The Court [in West Lynn Creamery] did not address whether the tax and subsidy program would have been legal if the tax first had been placed in the state general fund.").

389. See West Lynn Creamery, Inc. v. Healy, 512 U.S. 186, 210-11 (1994) (Scalia, J., concurring); see also supra text accompanying note 230 . But see supra note 238. 
had been paid from the general treasury to the taxpaying dealers themselves (based on their use of in-state milk), instead of to local producers? ${ }^{300}$ More to the point, it seems farfetched to suggest that West Lynn Creamery would have come out the other way if Massachusetts had only avoided the use of a segregated fund. After all, as we already have noted, both West Lynn Creamery and our posited case involve precisely the same amounts of money paid to and from precisely the same people at precisely the same time. To say in these circumstances that the two programs are distinguishable on fairness and federalism grounds subordinates, in the strongest fashion, substance to form.

\section{b. Political Processes}

A more plausible basis for distinguishing the segregated fund program from the general fund program arises out of the political dynamics justification for distinguishing subsidies from tax breaks as a general rule. As Justice Scalia could have noted, use of a segregated fund may diminish political checks on legislative retention of a subsidy by exempting the subsidy from annual appropriations review. ${ }^{391}$ Professor Drahozal put the point this way: "The money raised by the milk tax never made it to the general revenues. . . Thus, the pricing order ... allow[ed] beneficiaries to avoid the political restraints posed by well-organized competitors for government funds." ${ }^{\text {"392 }}$

One difficulty with such a political-process-based distinction of general fund and segregated fund cases is that it may overstate the significance of fund segregation. The creation of a segregated fund does not foreclose periodic review of the fund's existence, structure, and use; the state is still writing checks readily noticeable by other constituents who would like a piece of the action. Creation of a segregated fund thus does not immunize the subsidy portion of the program entirely from repeal, redirection, or reduction.

More importantly, it was not the establishment of a segregated fund that produced the basic political process difficulty that underlay invalidation of the Massachusetts milk scheme. The main problem resulted instead from the selffunding character of a tax-and-subsidy package, enacted as one measure, that offered (or at least appeared to offer) a way of exporting to out-of-state dairy

390. Probably, even the dissenters in West Lynn Creamen would have found a constitutional violation in these circumstances, given that their opinion focused nol at all on fund segregation. but insteas on the shared identity of the taxpayer and subsidy recipient. See supra text accompanying note 25S

391. The effects of such exemptions are discussed supra notes 122-125 and accompanying text.

392. Drahozal, supra note 33, at 1163. Indeed, pethaps foolishly. Massachusetts sought to defend its use of the segregated fund with just this line of reasoning. See Respondent's Bnef at 31. West Lynn Creamery, Inc. v. Healy, 512 U.S. 186 (199.4) (No. 93-141) ("Elımunatung the segregaled fund and depositing payments into the general fund would increase the politucal risk that the money would be used not only for the subsidy program, but also to defray the cost of providing all govemmental services...."'). 
farmers the full cost of in-state dairy farmer support. ${ }^{393}$ In such circumstances, regardless of fund segregation, political disincentives were weak with respect to putting the tax-and-subsidy program in place. At the least, the political dynamics at work when a state adopts such a unitary program differ radically from those at work when it enacts a monetary subsidy "standing alone." 394

The self-funding nature of the program also created a problematic political check on any legislative revision of the program to redirect milk taxes away from local dairy farmer subsidies to less protectionist uses. Again, however, this problem did not arise primarily because of the existence of a segregated fund. It arose instead from the inherently industry-specific character of the taxand-spending program, which provided dairy farmers with the ability to protest vehemently if state policymakers ever sought to end the subsidy without simultaneously ending the tax.

\section{c. Considerations of Form}

Justice Scalia was willing to characterize the Massachusetts subsidy as a tax "rebate" only because it was paid from a segregated fund. This fixation on Massachusetts's use of a segregated fund, however, does not square with Justice Scalia's own proper focus on whether the state's program should have been deemed too tariff-like because it embodied a discriminatory tax rebate. ${ }^{395}$ One simply cannot say it is more likely or more logical for rebates to come from a segregated fund than the general treasury. ${ }^{396}$ In addition, it is difficult to see why the Massachusetts program would have become less "tariff-like" in appearance if the only change made to it was to mix program funds with the state's general revenues. After all, as surely as the general treasury may provide the source of rebate payments, it also is the ordinary destination of typical tariff exactions. ${ }^{397}$

In short, courts should not limit the West Lynn Creamery principle to cases that involve segregated funds. Such a result would square with neither the majority's obvious disinclination to embrace this proposed distinction nor a

393. See supra text accompanying notes 358-359; see also Heinzerling, supra note 18, at 264 (arguing that the key to West Lynn Creamery was not the segregated fund, but that Massachusetts "funded the subsidy by taxing out-of-state firms in the same industry as the recipients of the subsidy").

394. West Lynn Creamery, 512 U.S. at 199.

395. See supra note 235 and accompanying text.

396. Cf. supra text accompanying note 258 .

397. Cf. supra text accompanying note 258; see also Drahozal, supra note 33, at 1148 ("In the extreme case of State $S$ funding the subsidy by a tax on widgets, the good being subsidized, the welfare consequences of the subsidy will be indistinguishable from those of a tariff."). 
functional focus on whether the tax-and-subsidy program is too tariff-like in effect. $^{398}$

\section{Simultaneity of Enactment}

What if a state enacts a milk program identical to the one at issue in West Lynn Creamery, but does so in two separate stages? In Year 1, the state imposes its milk-dealer tax. Then, in separate legislation in Year 2, it establishes the program's subsidy feature. Would this lack of contemporaneous enactment cause our hypothetical case to come out differently from West Lynn Creamery itself?

Justice Stevens's opinion suggests it might. In particular, his analysis focused on the propriety of the Massachusetts $\operatorname{tax},{ }^{399}$ and he found that tax objectionable because "Massachusetts dairy farmers, instead of exerting their influence against the tax, were in fact its primary supporters. ${ }^{+00}$ More specifically, in-state dairy farmers supported the new tax because they were "mollified by the subsidy," with which the tax was "coupled" when it was adopted. ${ }^{401}$

In our hypothetical two-step-enactment case, these dynamics are absent because in-state producers would obviously not be "mollified" when the state, in Year 1, enacts a genuinely across-the-board tax. Indeed, in-state dairy farmers would lead the charge against such a tax because its unmitigated burden falls on sales of their product. To be sure, in our hypothetical, these same in-state dairy farmers in Year 2 are able to out-muscle unrepresented outof-state competitors by securing a milk subsidy from a friendly legislature. But that does not bring our case within Justice Stevens's political process rationale because (to repeat the key point) his rationale focused on the legislative dynamics at work in enacting the $\operatorname{tax}^{402}$ Indeed, if we were to use Justice Stevens's political process argument to condemn our hypothetical in-staters' successful muscle-flexing in Year 2, that argument would prove too much because (contrary to Stevens's essential purpose in constructing that argument) it would logically require the invalidation of any discriminatory subsidy

398. Cf. Patterson, supra note 18. at 1027 n.330 (citing "simtlar protectionist effects of subsidies payd to in-state dairy farmers from the state's general fund. and subsidies pand from segregated funds"). But of. Sanifill, Inc. v. Kandiyohi County, 559 N.W.2d 111.116 n.4 (MInn. Cl. App. 1997) (invalıdang a seheme that involved a "service fee" placed on all local waste generators used in part to fund upping-fee reduetions for waste haulers that use the local facility, and notung that the "service foe is not. analogous to a general revenue tax because it ... does not go to the general fund").

399. See Heinzerling, supra note 18, at 263.

400. West Lynn Creamery, Inc. v. Healy, 512 U.S. 186. 200-01 (1991).

401. Id.

402. See id.; see also supra note 209 and accompany'ing text. 
"standing alone." ${ }^{403}$ In short, the key to Justice Stevens's political process distinction between the ordinary subsidy and the Massachusetts program was the simultaneous enactment of the subsidy and the tax. It follows that Justice Stevens-and a majority of the Court-might well decline to apply West Lynn Creamery to our hypothetical "two step" case. ${ }^{404}$

Justice Stevens's opinion, however, does not require this result, and courts should eschew it in light of considerations of symmetry and the effectscentered focus of the Court's dormant Commerce Clause authorities. ${ }^{405}$ After all, the milk program in our hypothetical case does not have just the same "practical effect" 406 as the actual Massachusetts program; it has exactly the same effect because it is exactly the same program. Lack of simultaneous enactment, moreover, does not rob the program of its most problematic features. First, once the subsidy is in effect, the overall program cannot be said simply to permit state residents to reap where they have sown. Instead, no less than in West Lynn Creamery itself, the program works, in self-funding fashion, to redirect money raised from sales of an out-of-state product to in-state producers. Second, our two-step case is indistinguishable from West Lynn Creamery with regard to facilitating federal experimentation; in both cases, subsidization of local dairy farmers-if truly necessary-could be paid for out of the state's general revenues. Third, while the political dynamics surrounding initial adoption of the two programs plainly differ, the two-step program-once in place-gives rise to the same political process problems present in West Lynn Creamery itself. In particular, regardless of simultaneity of enactment, built-in political pressures will impede efforts to strip in-state farmers' benefits away as soon as the unitary tax-and-subsidy program takes hold. This is so because the unitariness of the scheme, once in place, puts local milk producers in a strong position to insist that there should be no alteration of the subsidies they receive unless the tax on their own product also is withdrawn.

403. West Lynn Creamery, 512 U.S. at 199.

404. Cf. WLR Foods, Inc. v. Tyson Foods, Inc., 65 F.3d 1172, 1178 n.2 (4th Cir. 1995) (distinguishing "four distinct statutes enacted at different times" from the "single integrated scheme consisting of two parts" involved in West Lynn Creamery), aff'g 861 F. Supp. 1277, 1282 (W.D. Va. 1994) (stating that West Lynn Creamery "involved two statutes that the legislature intentionally joined together to create an integrated program," and noting that "[e]xtending West Lynn Creamery to non-integrated statutes not intentionally joined together... would create enormous difficulties"); Enrich, supra note 18, at 465 ("Contemporaneous enactment of the two would ordinarily favor [unitary] treatment.").

405. See, e.g., Associated Indus. v. Lohman, 511 U.S. 641, 655 (1994) (stating that to save one tax from discriminatory effect, another "need not be promulgated in the same provision of state law, or even through the same govermmental entity" and indicating that these "matters of form do not determine in substance whether the tax . . . discriminates against interstate trade"); Pelican Chapter, Associated Builders \& Contractors, Inc. v. Edwards, 901 F. Supp. 1125, 1138 n.45 (M.D. La. 1995) ("The fact that both West Lynn Creamery and Bacchus dealt with a new tax directed toward a particular policy as opposed to a preexisting, neutral tax is ultimately irrelevant.").

406. Complete Auto Transit, Inc. v. Brady, 430 U.S. 274, 279 (1977). 
Finally, whether enacted in one or two steps, the unitary tax-and-subsidy program "smells" no less like a tariff than the program deemed too tariff-like in West Lynn Creamery itself. The key in this regard is that once the state enacts the subsidy, its program is exactly the same as the one involved in West Lynn Creamery. When two programs are exactly the same, they look exactly the same. And when two programs look exactly the same, neither looks more like a tariff than the other. ${ }^{407}$

Viewed from another angle, the nonsimultaneous enactment of the tax and the subsidy may affect our ability to castigate the purpose of the state tax law because that law, on our assumed set of facts, was put in place for entirely evenhanded and nonprotectionist reasons. In fact, when the tax was enacted, it burdened in-state dairy farmers no less than out-of-staters. But state laws can offend the dormant Commerce Clause based on "either discriminatory purpose ... or discriminatory effect." ${ }^{408}$ After Year 2, our hypothetical milk program is no less discriminatory in effect than the program struck down in West Lynn Creamery. As a result, a court should probably strike it down. ${ }^{409}$

407. What if the subsidy had been put in place in Year I and the tax in Year 2" Perthaps the "subsidy first" situation differs from the "tax first" case because it is hard to sily that the proceeds of the new wa are the source of a subsidy that predated the tax's very existence. (And if the panticular tax is not the subsidy's source, then the source is the state's general revenues, so that the argument is stronger that subsidy recipients are reaping where the state's own citizens have sown.) On our assumed facts, however. the two-step enactment produces exactly the same result as in West Lynn Creamen-that is, the total volume of subsidy monies is determined directly by the total yolume of tax collections. In these circumstances (whether the tax or subsidy was enacted first). the procecds of the tax do in substance fund the subsidy. Of course, if this fact were changed-so that, for example, subsidy payments might or would exceed the total tax revenues, or at least revenues from out-of-state soures-we would have a very different case. In such a case, the combined lack of simultaneily of enactment and "source correlation" would probably lead a court to find the subsidy consututuonal Coenen \& Hellentein. supra note 90 . at 2216-17.

408. Bacchus Imports, Ltd. v. Dias, 468 U.S. 263. 270 (1984) (cutations omtled) (emphasis added). see also Associated Indus. v. Lohman, 511 U.S. 641.654 (1994) ("[W]c repeatedly have focused our Commence Clause analysis on whether a challenged scheme is discriminatory in "effect "'); ud. at 653 (" $"$ (A) cour need not inquire into the purpose or motivation behind a law to determine that in actuality "I impermissibly discriminates against interstate commence."): Chemıcal Waste Migmt., Inc. v Hunt, $50-1$ U S 334, 344 (1992) (noting that a finding of "economic protectuonism" could flow from esther disenminatory purpose or effect (quoting Wyoming v. Oklahoma, 502 U.S. 437. 454 (1992))): Minnesota v Clover Leaf Creamery Co., 449 U.S. 456, 471 n.15 (1981) (allowing a finding of economic prolectionism based on "proof either of discriminatory effect ... or of discriminatory purpose" (citations omitled)).

409. There is some reason to believe that Justuce Scalia would share this vew in light of his dissentung remarks in American Trucking Ass'ns v: Scheiner, 483 U.S. 266 (1987). In that case, out-of-state truckers made the argument (not reached by the Cour's majonty) that a flat-axle tax imposed on truckers by Pennsylvania discriminated against interstate commerce because a simultancousiy enacted law "reduced registration fees for Pennsylvania-based trucks by, for all practical purposes, precisely the amount of the axle taxes." Id. at 304 (Scalia, J., dissenting). In rejecting this contention. Justuce Scalıa wrote.

[W] hat if Pennsylvania had enacted the axle tax without reducing registration fees, and then one year later made a corresponding reduction in truck registration fees? This case, of course, is more difficult than [the hypothesized one] because the tax reduction and axle tax ... were enacted simultaneously. However, to inquire whether a tax reduction is close enough in time ... to another tax so that "in effect" the latter should be treated as facially discnminatory is to ask a question that has no answer. 
This is not to say that nonsimultaneity of enactment will be irrelevant in all cases. Unquestionably, our two-step hypothetical provides a less compelling case for judicial intervention than does West Lynn Creamery. While courts probably should reach the same result in both cases, this conclusion largely flows from the precise equivalence of the two programs once the subsidy takes effect. It is possible to envision cases in which additional differences exist: for example, when there is nonsimultaneous enactment and the purported "rebate" comes in the form of a nonmonetary benefit, such as agricultural extension services. In such a situation, nonsimultaneity of enactment may combine with the noncash nature of the subsidy to negate its characterization as a tax rebate. ${ }^{410}$ In short, nonsimultaneity of enactment should and will count in many cases. ${ }^{411}$ Sometimes, however, it will not count enough to negate application of the West Lynn Creamery principle.

\section{The Cumberland Farms II Conundrum}

In Cumberland Farms, Inc. v. Mahany (Cumberland Farms II), ${ }^{412}$ the federal district court for Maine confronted a complicated tax-and-subsidy problem. In January 1995, following the invalidation of the Maine milk subsidy program in Cumberland Farms $I,{ }^{413}$ the legislature adopted a new

Id. at 305. If simultaneity of enactment was not important to Justice Scalia in Scheiner, it is hard to sec why it should be important to him in West Lynn Creamery. The "question that has no answer"-as to how simultaneous is simultaneous enough-is equally present in both situations.

410. Cf. Reeves, Inc. v. Stake, 447 U.S. 429,442 n.16 (1980) (suggesting that agricultural extension service programs are ordinarily permissible under the dormant Commerce Clause even though made available only to in-staters).

411. Cf. Sheehy v. Public Employees Retirement Div., 864 P.2d 762 (Mont. 1993) (relying. in characterizing increases in retirement benefits as tax rebates for purposes of the intergovernmental tax immunity doctrine, on the simultaneity of enactment of the increases with the repeal of a discriminatory tax exemption afforded to state but not federal retirees in violation of Davis v. Michigan Department of Treasury, 489 U.S. 803 (1989)). In a similar vein, simultaneity of enactment of a tax and subsidy will not always establish that the two are unlawfully linked. Assume, for example, that a state simultancously imposes a tax on all barge operators, principally headquartered outside the state, while simultancously enacting a subsidy for owners of transport trucks licensed within the state. (This hypothetical is based loosely on a scenario described in Scheiner, 483 U.S. at 304-05 (Scalia, J., dissenting).) In this situation, can we say that the tax and the subsidy are linked in a way that produces prohibited discrimination against interstate commerce? I think not. After all, even with simultaneity of enactment, there is no overlap at all between taxed and subsidized businesses so that the "discriminatory" subsidy does not even remotely resemble a rebate of the tax. In particular, West Lynn Creamery is readily distinguishable on this ground. See Coenen \& Hellerstein, supra note 90 , at 2229 n.296. Nor (without substantially more) would the instate transport-truck subsidy violate the Commerce Clause if both in-state and out-of-state truckers werc required to pay, both before and after adoption of the subsidy, state-imposed general corporate income taxes. All corporations doing business within a state pay that state's corporate income tax. Thus giving cash grants to some but far less than all in-state corporate taxpayers involves just the sort of "ordinary subsidy" that is permissible under the general subsidy-protective rule.

412. 943 F. Supp. 83 (D. Me. 1996).

413. Cumberland Farms, Inc. v. LaFaver (Cumberland Farms I), 33 F.3d I (Ist Cir. 1994); see supra Subsection V.B.I. 
law that placed a tax on all wholesale milk transfers, with resulting proceeds payable into the state's general treasury. Then, in February 1995 and June 1995 , the legislature adopted two appropriations bills directing that a total of $\$ 5,550,000$ be distributed from the general treasury to fund subsidy payments to Maine milk farmers. This tax-and-subsidy scheme promptly encountered a constitutional challenge based upon West Lymn Creamery. ${ }^{\text {is }}$

The court-evincing a sensitivity to the emerging law in this area-described the issue as whether "the 1995 [tax] is legally separate from any later appropriations of General Fund monies"sis or whether "their alleged relationship" rendered them invalid. ${ }^{416}$ In the court's opinion, the tax and appropriations measures did not reflect the sort of "intentional[] link[]" present in West Lynn Creamery because there was no "combination of the two components within a single statute."17 Having thus distinguished West Lynn Creamery, the court concluded that the dispositive question was whether it should "look beyond the 1995 Act itself to infer from the political and legislative context that, in passing the 1995 Act, the Maine Legislature acted with an improper purpose." 18 Turning to that question, the court acknowledged that "it appears that the Legislature intended to circumvent the Court's decision in West Lym Creamery by simply pulling apart the two components of the [previously invalidated] $1991 \mathrm{Act}$, and reenacting them individually." 119 Nonetheless, the court refused to consider "the hidden motives of the legislature." ${ }^{20}$ Instead, citing a treatise on statutory construction, the court declared that it could look only at "the face of the statute" and had to assume that the legislature "acted with integrity and with an honest purpose." ${ }^{221}$ Accordingly, the court found that the principle of West Lynn Creamery did not apply to the revised tax-and-subsidy scheme and proclaimed it constitutional. ${ }^{422}$

Cumberland Farms II raises profoundly difficult issues of dormant Commerce Clause linkage analysis, and in addressing those issues, the court took two significant missteps. The court first floundered in its treatment of legislative purpose. To be sure, there are cases that caution against judicial inquiry into legislative motive. ${ }^{423}$ Purposive analysis, however, is nowadays

414. For a more detailed descnption of the facts of Cumberland Furms 11 , sec 943 F Supp at 85-86.

415. Id. at 87 .

416. $I d$. at 86 .

417. Id. at 87 .

418. Id.

419. $I d$.

420. $I d$.

421. Id. (citation omitted).

422. See id. at 89-90.

423. See, e.g., United States v. O'Brien. 391 U.S. 367. 383 (1968) (“Inquines into congressional motives or purposes are a hazardous matter."): Henneford v. Silas Mason Co., 300 U S 577.586 (1937) 
commonplace in constitutional law, ${ }^{424}$ including dormant Commerce Clause cases. ${ }^{425}$

As Professor Hellerstein and I have explained elsewhere ${ }^{426}$ (and the court asserted in Cumberland Farms $I^{427}$ ), the purposive-discrimination principle applicable in Commerce Clause cases should not alone control the constitutionality of a tax-and-subsidy scheme. There is, after all, an essential difference between asking: (1) whether a single challenged law was enacted with a "discriminatory purpose"; and (2) whether two different laws, each of which would be constitutional standing alone, should be treated as a unitary whole. To say that the ban on discriminatory purpose alone is not controlling in linkage cases, however, is not to say (as the court also asserted in Cumberland Farms $I^{428}$ ) that legislative purpose should have no role of any kind in linkage analysis. Instead, as we shall soon see, legislative purpose may play a part, at least in special circumstances, in a policy-driven appraisal of dormant Commerce Clause subsidy cases. ${ }^{429}$ The court thus erred in ignoring the purpose that lay behind Maine's enactment of its tax-and-subsidy scheme.

The court's second error was more fundamental. Having deemed legislative purpose irrelevant to its inquiry, the court asserted that the 1995 tax act and the ensuing appropriations measures raised no constitutional problem because they constituted "a non-integrated statutory scheme." ${ }^{430}$ But whether the Maine program properly merited description as "non-integrated" was a highly debatable proposition, given the contextual and temporal connections between the Maine subsidy and the Maine tax. In essence, the Maine court simply assumed its critical conclusion, leaving without explanation why the Maine scheme was functionally distinguishable from the program invalidated in West Lynn Creamery.

Proper analysis of a case like Cumberland Farms II requires consultation of underlying dormant Commerce Clause policies, and a fair consideration of those policies reveals why the Maine case was distinguishable from West Lynn

("[M]otives alone will seldom, if ever, invalidate a tax that apart from its motives would be recognized as lawful.").

424. See, e.g., Church of the Lukumi Babalu Aye, Inc. v. City of Hialeah, 508 U.S. 520 (1993) (Frec Exercise Clause); Wallace v. Jaffree, 472 U.S. 38 (1985) (Establishment Clause); Hunter v. Underwood, 471 U.S. 222 (1985) (Equal Protection Clause). See generally John Hart Ely, Legislative and Administrative Motivation in Constitutional Law, 79 YALE L.J. 1205, 1208-12 (1970) (noting cases involving purposive analysis). (1981)

425. See, e.g., Minnesota v. Clover Leaf Creamery Co., 449 U.S. 456, 463 n.7, 471 n.15, 476 n.2

426. See Coenen \& Hellerstein, supra note 90, at 2193-94.

427. See Cumberland Farms, Inc. v. Mahany (Cumberland Farms II), 943 F. Supp. 83, 87-89 (D. Mc. 1996).

428. See id.

429. See infra text accompanying notes 444-447.

430. Cumberland Farms II, 943 F. Supp. at 87. 
Creamery. That analysis also reveals however that the Maine case presented a distinctive problem that raises serious doubts about whether the court reached the right result.

\section{a. Fairness and Federalism}

With respect to fairness and federalism, the revised Maine milk scheme differed from the program struck down in West Lynn Creameny because, for two separate reasons, the Maine program lacked so-called "source-based correlation." ${ }^{431}$ First, unlike in West Lymn Creamery, Maine's milk tax proceeds were placed in the general treasury and not "set aside . . to fund its payment program.."432 Second, the subsidy payments made in Maine were a fixed amount, and thus not (as in West Lynn Creameny) a floating "function of tax receipts." ${ }^{433}$ In particular, because the Maine legislature appropriated monies for milk subsidies in the specific and limited amount of $\$ 5,500,000$, it was possible that future milk tax collections would not cover the cost of the milk subsidy. Given this circumstance, it was easier to say in Cumberland Farms II than in West Lynn Creamery that the state was genuinely spending its own money so as to allow its own citizens to reap where they had sown.

At the same time, these distinctions may not justify the different results in Cumberland Farms II and West Lynn Creamery. First, the segregation of subsidy-funding tax proceeds in West Lynn Creamen-although critical to Justice Scalia-was not a point of significance for the Court's majority and should count for little, if anything, in cases of this nature. ${ }^{34}$ In a like vein, while it was possible that Maine's milk tax collections could fall short of paying for the fixed amount of appropriated subsidies, there is no reason to assume that this was so. If the facts showed that milk tax collections were sure to exceed subsidy costs, the revised program, as a matter of "practical effect," 435 would be marked by the same "wash-plus-tariff character" that infected the West Lynn Creamery scheme. ${ }^{436}$

\section{b. Considerations of Form}

Considerations of form also provide a possible basis for distinguishing Cumberland Farms II from the West Lynn Creamery case. The Maine

431. Coenen \& Hellerstein, supra note 90 , at 2200

432. Id. at 2201.

433. Id.

434. See supra Subsection V.B.2.

435. Complete Auto Transit v. Brady, 430 U.S. 274. 279 (1977)

436. See supra text accompanying note 345 . 
program, in contrast to the Massachusetts program, was put in place by way of separate legislative enactments instead of one unitary government pronouncement. In essence, the court accorded this fact dispositive significance. ${ }^{437}$ Such an approach, however, is wrong because it woodenly emphasizes form over substance and would invite easy evasion of the West Lynn Creamery rule through the readily available device of enacting two laws rather than one. ${ }^{438}$

A better argument for removing Maine's subsidy payments from the "tax rebate" category is that those payments were not marked by the sort of "computational correlation" that exists, for example, when both the tax and the subsidy are "a stated percentage of gross receipts." ${ }^{\text {"3.* }}$ Computational correlation constitutes an important factor in linkage cases because it is hard to deny that a linkage between a subsidy and a tax exists when, for each favored taxpayer, what is received as a subsidy fluctuates in direct proportion to what is paid as a tax..$^{40}$

Yet, while computational correlation will often matter in tax-subsidy linkage analysis, it was absent in West Lynn Creamery, just as it was in Cumberland Farms II. ${ }^{411}$ Thus, while this consideration may have served as a background factor that weakened the case for linkage in Cumberland Farms II, it cannot serve to distinguish that case from West Lymn Creamery.

\section{c. Political Processes}

The most important distinction between West Lynn Creamery and the Maine case concerns differences of political dynamics. To begin with, the Maine tax and the Maine subsidy were not enacted at the same time, while in West Lynn Creamery, simultaneous enactment of the milk tax and subsidy played a critical role because it facilitated the mollification of local milk producers who would otherwise have opposed enactment of the tax. It is doubtful, however, that the sort of nonsimultaneity present in the Maine case ought to count for much because "literal simultaneity should not be required to bring this factor into play." 442 Instead, "substantial simultaneity-like substantial performance in the law of contracts-ought to suffice."

437. See supra text accompanying notes $417-422$.

438. Cf. supra note 252 and accompanying text (criticizing Justice Scalia for permitting casy cvasion of the West Lynn Creamery rule).

439. Coenen \& Hellerstein, supra note 90 , at 2200.

440. See id. at 2218-19.

441. See id. at 2217 n.237.

442. Coenen \& Hellerstein, supra note 90, at 2199.

443. Id. (footnote omitted). 
In Cumberland Farms II, the case for finding substantial simultaneity was strong because the appropriations measures that favored local farmers were enacted within months of the milk tax. ${ }^{.45}$ To be sure, "neither the legislators nor the farmers could guarantee that the revenues generated by the 1995 Act would be returned to the farmers in the form of a subsidy." true that the 1995 Act "responded to the invalidation of the 1991 Act" that "certain legislators indeed hoped to enact appropriations in the wake of the $1995 \mathrm{Act}^{\text {"447 }}$ (points that the court declined to investigate), it is hard to view the Maine case as involving the sor of strong nonsimultaneity that would significantly distinguish it from the West Lynn Creameny case.

The Maine program, however, differed from the Massachusetts program in another important way because the Maine program lacked what has been called "durational correlation." 448 This factor was missing in Cumberland Farms II because, unlike in West Lynn Creamery, the milk tax and milk subsidy did not have a built-in common lifespan. Instead, while the Maine tax came into being by way of ordinary - and thus presumptively permanentlegislation, the Maine subsidy was put in place as a single one-year appropriation of a limited, fixed amount. This fact meant that the subsidy in Cumberland Farms II shared, in a strong way, two of the characteristics that cause typical subsidies to present fewer dangers of overextension than the typical discriminatory tax break. First, because the Maine subsidy was finite as to time, it was necessarily subject to reexamination (and very possibly to nonrenewal) in the high visibility and inherently competitive annual appropriations process. Second, because the Maine subsidy was finite in amount, it was subject to the empty cookie jar check that is inapplicable to the ordinary open-ended tax break.

For all of these reasons, the Maine subsidy was sufficiently different from the subsidy struck down in West Lynn Creamery that a court, without more, could find the cases distinguishable. But, in fact, there was something more, and this additional factor, although unmentioned by the Maine Supreme Cour, transformed Cumberland Farms II into a much more difficult case.

\section{d. Constitutional Remediation}

Cumberland Farms II presented a distinctive policy problem due to

444. See supra text accompanying notes $413-414$.

445. Cumberland Farms, Inc. v. Mahany (Cumberland Farms II), 943 F. Supp 83.88 n I (D Me. 1996).

446. Id. at 87 .

447. Id. at 88 n.l.

448. Coenen \& Hellerstein, supra note 90, at 2200. 
guiding principles of constitutional remediation. This problem arose because Maine legislators did not write on a clean slate. Instead, they acted against the backdrop of having previously implemented the tax-and-subsidy policy specifically found to be unconstitutional in Cumberland Farms 1 . The new program thus might never have existed but for the legislature's adoption of its constitutionally tainted predecessor. Yet a basic principle of constitutional remediation requires the state "to restore the victims of discriminatory conduct to the position they would have occupied in the absence of such conduct." In the Maine case, this principle would seem to require invalidation of the 1995 program if, in fact, it was passed only because the unconstitutional 1991 program had previously been put in place. A grave difficulty arises in applying this principle, however, because it is impossible to know (in light of altered private expectations, legislator loyalties, and other political dynamics) whether "in the absence" of the 1991 legislation, the 1995 program would have come into being. ${ }^{450}$

Some authority from analogous contexts suggests that, in these circumstances, doubts should be resolved against the "wrongdoer" state. 451 There are cross-currents in the cases, however, ${ }^{452}$ and a less wooden and more measured approach would treat this fruit-of-the-poisonous-tree risk as only one factor to be weighed in the linkage calculus. ${ }^{453}$ From this perspective, for example, Maine would not have violated the Commerce Clause if in 1995 it had adopted a local dairy farmer subsidy payable from the general treasury, without any new milk tax at all, even though that subsidy might well not have been passed but for the earlier adoption of the 1991 tax-and-spending program. In such a case, the stand-alone subsidy, when viewed in isolation, is so far removed from the constitutional precipice that added fruit-of-thepoisonous-tree concerns would fail to push it over the edge.

The tax-and-payment scheme at issue in Cumberland Farms II, however, was not a freestanding milk production subsidy. Instead, it bore an unmistakable relationship to a specific milk industry tax. To be sure, a strong

449. Milliken v. Bradley, 418 U.S. 717, 746 (1974) (emphasis added); accord, e.g., United States v. Virginia, 116 S. Ct. 2264, 2282 (1996).

450. See supra text accompanying note 449.

451. See Mount Healthy Bd. of Educ. v. Doyle, 429 U.S. 274, 287 (1977) (placing the burden of proof on a defendant-employer to prove a lack of but-for causation when the plaintiff shows that retaliation for exercise of free speech rights contributed to dismissal); see also Zenith Radio Corp. v. Hazeltine Research, Inc., 395 U.S. 100, 124 (1969) (noting that in determining the measure of antitrust damages caused by the defendant, juries are given broad discretion because "[a]ny other rule would enable the wrongdoer to profit by his wrongdoing at the expense of his victim" (quoting Bigelow v. RKO Radio Pictures, Inc., 327 U.S. 251, $264($ (1946))).

452. See, e.g., Price Waterhouse v. Hopkins, 490 U.S. 228, 282 (1989) (Kennedy, J., dissenting) (noting that "[c]ommon-law approaches to causation often require proof of but-for cause" by a plaintiff).

453. See Coenen \& Hellerstein, supra note 90, at 2224. 
case can be made for distinguishing the tax-subsidy relationship in Cumberland Farms II from the tax-subsidy relationship present in West Lynn Creamery. ${ }^{454}$ But it is fair at least to say that the case is close even if we put concerns of constitutional remediation to one side. ${ }^{455}$ In the end, while the matter is one of judgment, policy concerns about ensuring full remediation of constitutional wrongs bolster the view that the 1995 Maine tax and 1995 Maine subsidy were sufficiently linked to give rise to a violation of the dormant Commerce Clause.

\section{CONCLUSION}

In this Article, I have dealt with the two main constitutional questions that overhang state subsidy programs in the post-West Lynn Creamen' era. The first question is whether ordinary business subsidies-which, like typical spending programs, are not distinctively connected to any particular tax-are unconstitutional. Drawing on considerations of Commerce Clause policy, which are touched on but not fully developed in the earlier literature, I argue that the answer to this question should be "no." This conclusion should dispose of most Commerce Clause issues in this area and will provide a safe harbor for states that genuinely need to give financial aid to distinctively valued or struggling lecal industries.

The second question is how to decide whether challenged subsidies that have an arguable connection to a particular tax merit invalidation under West Lynn Creamery or protection under the competing ordinary-subsidy principle. I argue that the hand that draws this line should be guided by the same policies that give rise to the basic distinction between the constitutional ordinary subsidy and the unconstitutional discriminatory tax break. It is true that the multifactor approach I propose will produce a measure of uncertainty and a need for practical judgment in some cases. But that result is neither surprising nor bad. When powerful, countervailing constitutional principles collide, some measure of difficulty in doctrinal line-drawing is inescapable. In this Article, I have not laid out how courts should decide each and every permutation of West Lynn Creamery. I have, however, offered a structured, policy-driven framework for applying a "law of linkage" in the dormant Commerce Clause field.

454. See supra Subsection V.B.4.c.

455. See Note, supra note 31, at 1553-54 (challenging, without any reference to remedtation concerns, the court's ruling in Cumberland Farms II). 
HeinOnline -- 107 Yale L.J. 1054 1997-1998 